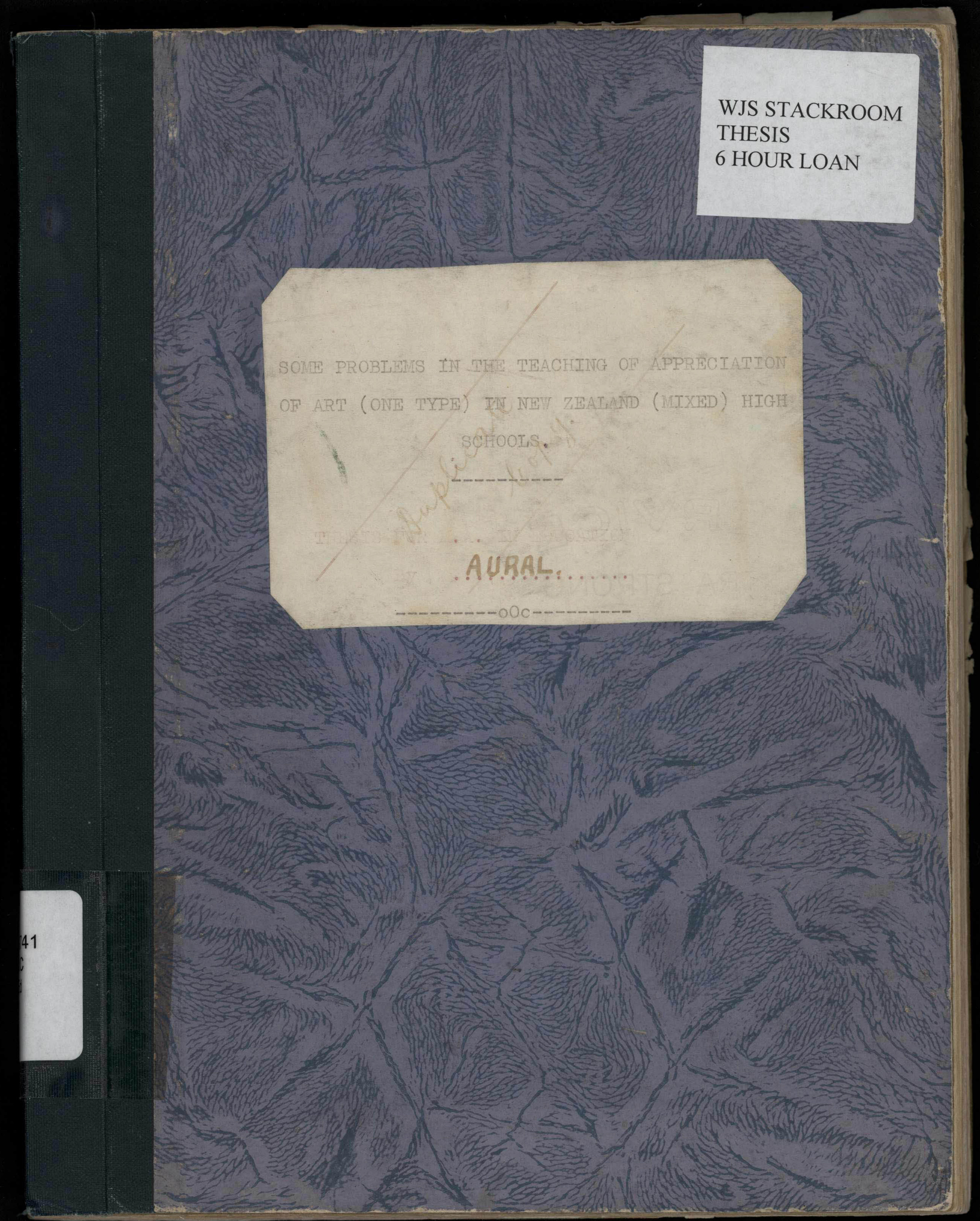














\section{IABLE OF CONTENTS.}

Page

1. Introduction .........................

11 Enviromment ......................

111 Lessons in Appreciation ................

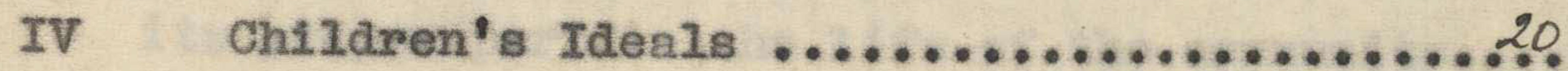

V. (a)Colour Preferences ....................... 2द

(b) Colour Preferences of Maor1 children .......38.

VI. Colour, Form and Religious Associations ... 43

VII. Influence of the size of Pletures .........

VII. Effects of Colour Blindness on Appreciation $\$ 2$

IX. Hefects of constantly seeing pictures ..... 5.4

X. (I) The Extravert and Introvert Types .........6!

(II)The Types in school .................6

(III)The Types in Art .....................

(IV)The reactions of Chlldren of the two types to pictures by extravert and introvert artists.

XI. Grading of Pletures ................... 86

XII. Conclusion ......................... 92

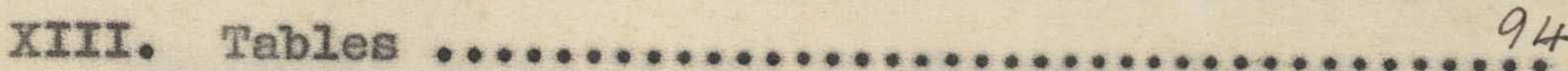

XIV. Appendices. (I) Reasons for the choice of occupations among primary school pupils ............ 6

(II)The extrevert and introvert types in poetry ......... 156

Blbliography $\ldots \ldots \ldots \ldots \ldots \ldots \ldots \ldots \ldots \ldots \ldots$ 


\section{INTRODUCTION}

It is becoming abundantl $y$ evident that art

instruction in New Zealend high gchools must concern itself with something mo e then the practice of drawIng and it $s$ a.11ed crafts if plctorial Art is to play 1ts proper part in the 1ife of the community. The fact that a very large, number of so-called "well-educated" people disclaim ary real knowledge of pictorial art shows how Ineffective our system of ert education las been in the past; and although the practice of painting (1ike the practice of medicine or engineering) may be a secial subject, yet the power to appreciate and enjoy the work of the artist should belong to every man, woman and child. If we consider it necessary to train children in the appreciation of 11 terature and music we must do the same with painting, for the latter is just as much a vehicle for the expression of thought and emotion as our om tongue. Derhaps it is not too much to say that the indfference to beauty - or rather, the toleration of ugliness - shown by the average New Zeajander today is due to the fact that art teaching In the pest has been more concerned with skill of hand than the appreciation of beauty, and thus a grave error has been committed. The aim of the drawing teacher must not be to produce large numbers of indifferent artists. He cannot cause men of genius to be born nor 
can he create master painters by mere instruction in the art of painting. The art teacher can, however. provide a public, nemely ourselves, for the artist, who $w 111$ encourage that axtist to be an artist, to do his best, not his worst.

- The quality of art in any age and in any place depends, not upon the presence or absence of individuals of genius, but upon the attitude of the public towards art. The teacher cannot make artists directly but he can grimx aim at a state of society in which they wi11 be encouraged to do their best, and at a state of mind In which all shall learn to know good from bed, and to prefer the good. In New zealand at present we have neither the state of society nor the state of mind.

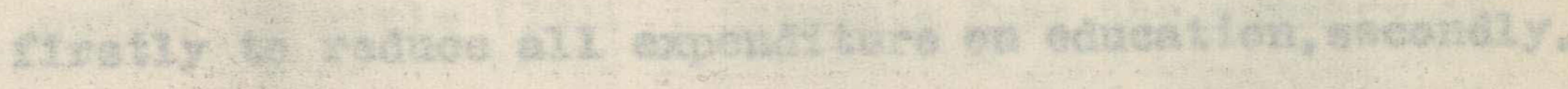

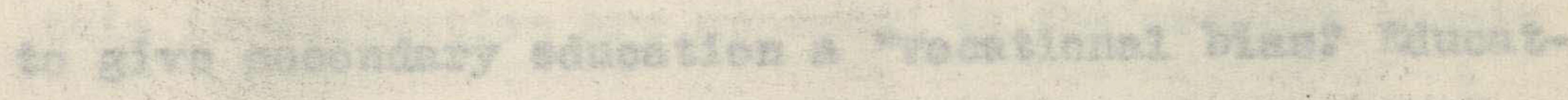

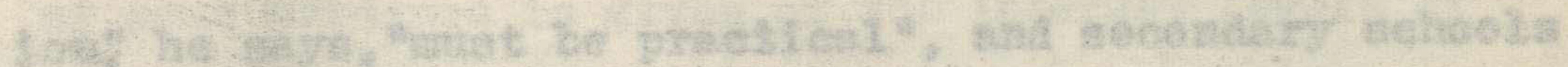

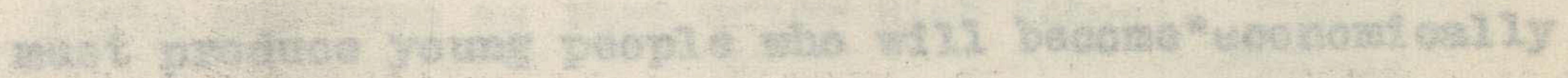

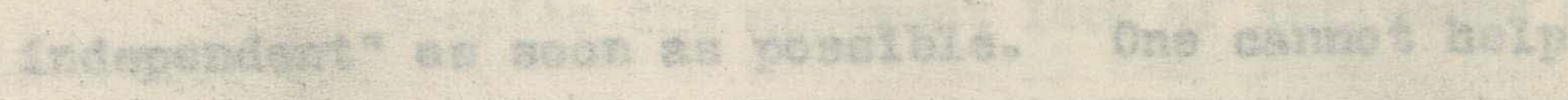

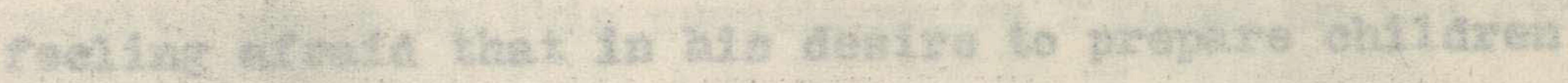

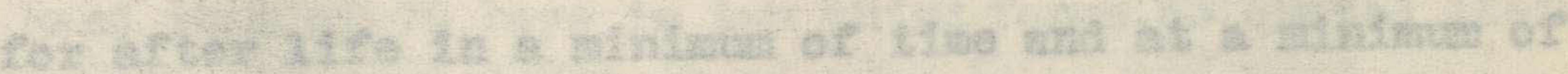




\section{EVVTRONYrATT}

Within a radius of one hundred miles of the school In which this thesis is being written there are over three milizons of sheep, helf-a-militon cattle, nearly one hundred thousend horses and two hundred thousand pigs. New Zealanders are obsessed with the thought that the prosperity of the country rests upon 1 ts primery products, and in both the country and the towns, dalry produce, wool and frozen mutton are the comnon topies, of conversation. The prevaiting trada depressIon hes had the effect of stimulating the peoples pride in thelr araftsmanship, ohiefly, however, with a view to extending markets. The expressed determination of the last Minister of Education to give the curriculum of secondary gchools a "declded agriculturel bias" is still admired by the mejority of parents, but this determination fortunetely has not been realized, for the Portfolic of Education has now been placed in the hands of a Minister who declares that his aims are twofold firstly to reduce all expendlture on education, secondly. to give secondary education a "rocational bias" Fducatfon" he says, "must be prectical", and secondary schools must produce young people who will become"economically Independent" as soon as possible. One cannot help feeling afraid that in his desire to prepare children for after $11 f$ in a minimum of time and at a minimum of 
of expense he may for ever stunt the spiritual and mental growth of those very children.

The influence of adults in New Zealand in directing and moulding the tastes of their children is very apparent. The children themselves are apparentiy not conscious of this until the period of adolescence is well advanced, but there is room for investigation here. In a questionaire presented to all the pupils in Standards VI and VII of the primary schools of one education district, the pupils were asked amongst other things to name the trade, profession or calling they would like to follow, and to give as briefly as possible the reasons for their choice. The average age of the 460 boys who answered the questionnalre was 13 years and 4 months while the average age of the $479 \mathrm{girls}$ who answered the same questionnaire was I3 years I month. Only 28 boys named as the reason for their choice the opinion, suggestion or advice of some adult, yet this number was more than double the number of girls (I2). Axtracts from the sumnary of this investigation are appended to the present thesis as some evidence is given of the interest levels of girls and boys as they enter High School.

Despite the apparent lack of influente of

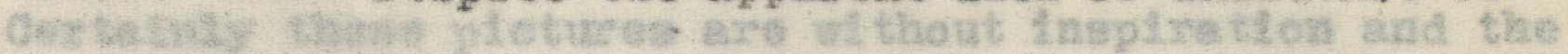
adults shown by this questionnalre. I found on the other hand that of 70 boys in two third forms, 53 quoted their father's opinions on each of six topical questions set

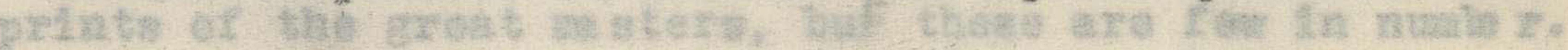


for reference and preparation, and that of $49 \mathrm{girls}, 36$ on the same series quoted their mother's opinions while 10 quoted their father's opinions. These results only bear out my own observations, for I have noticed in my personal visits the definite share that the children take in family discussions. Children occasionally address their parents by their Christian names, and frequently attend sporting and other social events in company with their elders.

Adult influence is shown in another field - 450 pupils in this school were asked to name their favourite pictures and also to give a list of the pictures adorning the walls of their homes, 142 pupils ( 37 boys \& 105 girls named as their favourite pictures those at home, and gave as their reason "it was painted by my mother". This influence is one which the teacher of art appreciation will frequently have to strive hard to combat. The pictures "at home" I have found by prsonal visits to be nearly always hideous oil-paintings, generally of Milford Sound, of vivid sunsets or of florid "bunches" of New Zealand flowers. I found on enquiry that very few of the artists had ever viaited Hilford sound and that the impressions of flowers are second-hand. Certainly these pictures are without inspiration and the technique in nine cases out of ten is crude in the extreme. In some homes it is true there are some good prints of the great masters, but these are few in number. 
In no 1 ess than 130 homes I find from the questionnaire are there third-rate prints of Phar Lap, a race-horse which was bred in New Zealand and recently tragically poisoned in Agua Caliente, Mexico. These prints have been given away free to householders upon purchasing a pound of a well known brand of tea. Photographs of wedding and family groups and of the "All Blacks", indifferent calendêrs and racing prints, and frightful oils

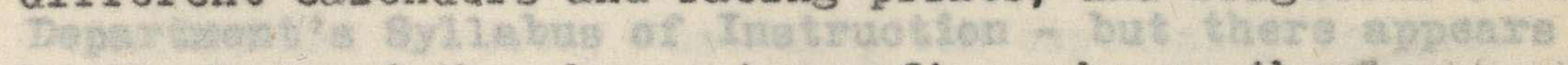
by the lady of the house too often make up the "artistic" environment of the child. There are of course, a large number of people who will always relish inferior pictures - those who prefer the best are few and and we must not be too sure that the poorest picture so long as it does not offend against public morality has not its function in art and life. Indeed if we could accurately reckon up and balance the influence exerted by pictorial art, we might not improbably find that the influence of third rate pictures is greater in the aggregate than those of the first rate, for my enquiries have established the fact that third rate pictures appeal to an infinitely greater number of people. It should, however, be the ambition of the teacher that all will want only really good pictures about them. If the children from their childhood onwards come to love pictures, to understand them and have learnt how to study and criticize them, the demand for good pictures will result in that demand being 
satisfied: and education will make the painting of pictures almost as common a thing as the appreciation of them.

That use is made of pictures in the primary schools is so small at present that it can almost be disregarded. Teachers will find "appreciation of art" mentioned in four different places in the Education Department's Syllabus of Instruction - but there appears to be very little recognition of this in the classroom. I found that apart from Raeburn's "Boy with a Rabbit" and Somersell's "off Valparaiso" third form girls and boys had but 11 ttle or no recollection or appreciation whatever of the pictures they had seen in the primary schools. Their attitude to pictures on entering High School is one of blank indifference.

Nor is the position at present much better in the secondary schools. A few prints of the great masters have been hung on the walls of one or two classrooms of some of the schools, and several teachers have told me that they have occasionally used prints of the great masters to illustrate points that have "cropped up" in the course of lessons - especially in history. Beyond this there has been no attempt to use art as a socializing factor in the school, nor to teach systematically the appreciation of pictures with due regard to the needs of the child and with the social 
demands with which he will later have to comply.

The causes for these state of affairs appear to be threefold:-

(1) The egotistical New Zealand people, tucked away in a far off corner of the world, condemning all who do not think as themselves, often definitely unsocial if not unmoral in their outlook, decry all that is not directly "useful", and especially do they wish to prevent the introduction of what they call

"the frills of education", This attitude is reflected for instance in the number of art galleries and amateur art socilties in existence. Although the population of New Zealand is now well over $1,600,000$, the number of art societies and art galleries at present in existence is not more than twenty:

(2) The work in the secondary schools is almost wholly confined to preparing pupils for certain public examinations on the one hand, and to improving the physique of the pupils by military drill and games (especially Rugby football for the boys and basket-ball for the girls) on the other. Neither of the examinations just mentioned require any Knowledge of pictures to fulfil their requirements, and the work in the classroom is almost wholly confined to the business of gaining a rudimentary

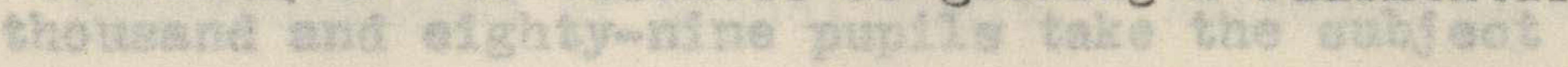


Knowledge of Jnglish Grammar, a smattering of 11 terature, a superficial Knowledge of the fundamentals of either Chemistry or physics, or magnetism and electricity or agriculture (home science is the science subject for girls--but its syllabus nearly coincides with that of chemistry for boys), the rudiments of either Brench pr latin. The rest of the time is spent in "doing" in a totally inadequate and obsolete way, such subjects as geography, history, bookkeeping and hygiene. A teacher has been considered to be a good one if his pupils have year after year "passed" these examinations, and in no subtle way is he made to feel that anthing taken outside the syllabus of instruction. is unwelcome and a waste of the pupils' time. Appreciation of pictures, being an unknown subject is to be neglected and left severely alone. The new School Leaving Certificate introduced by the Foucation Department this year (1934) does not hold out much hope for a change in this state of affairs. This is the position at present. There are forty-four High Schools In New Zealand (this does not include Technical High Schools nor Distriçt High Schools). Drawing is taught in thirty-nine of these schools, and nine thousand and eighty-nine pupils take the subject 
( 4397 boys, 4692 girls). Of these schools twelve also include Arteraft in the curriculum, but Art Appreciation is rarely mentioned as a special subject in the curriculum al though an inspection of schemes of work reveals that some teachers of art do give some portion of the time to appreciation. The time given to the subjects varies so much from school to school and from form to form within the school that it is quite impossible to state generally the amount of time that is allotted on time-tables to these subjects. Three-quarters of an hour to one and a half hours is a usual variation within the school ${ }^{\circ}$ About fifteen schools are giving between two and three hours in some of their classes, which a very few schools allow four, five or six hours to special pupils. (3) There are many teachers who do recognize the immense value of the systematic study of pictures, but, apart from the fact that they have not definitely decided in their own minds the place to be assigned to the study in the curriculum, they feel that they are ignorant both of the subject and of the methods of teaching their pupils to appreciate good pictures. Until comparatively recently we were very fortunate in having as an advisor a Superintendent of School Music. Although he was the only person recognized by the moucation 
Department to help teachers, nevertheless his advice given by means of articles, lectures and supervision greatly helped music in our schools. But with regard to pictorial art we have had no such help. The little training in appreciation that teachers receive at Training College has been far from adequate, and $I$ suggest thet art appreciation must definitely be included in the Training College curriculum if the subject is to play a larger part in life both inside and outside the school.

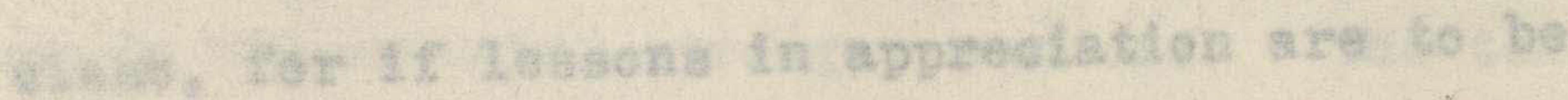

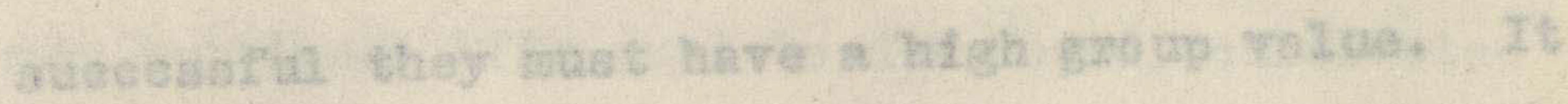

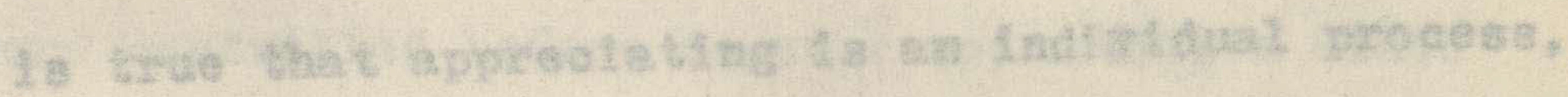

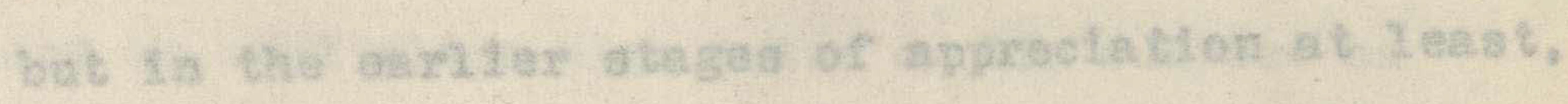

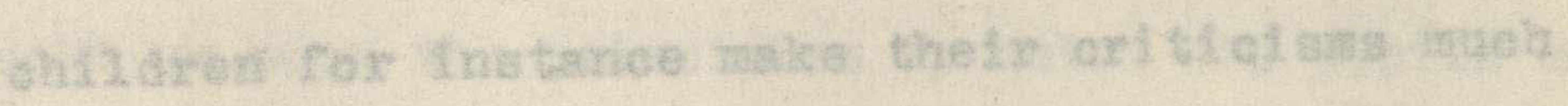

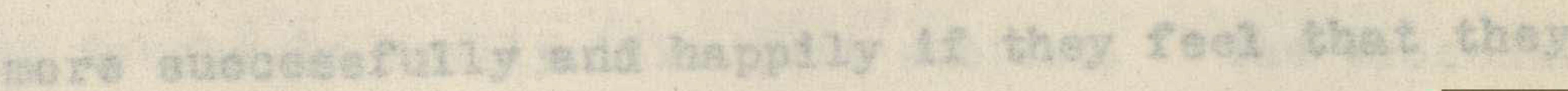

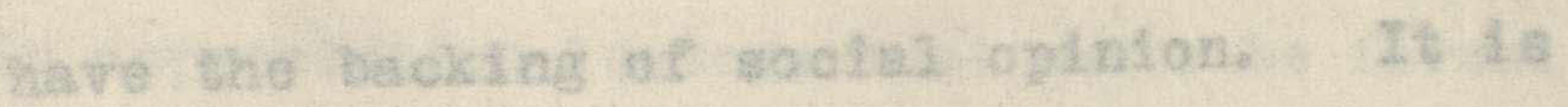

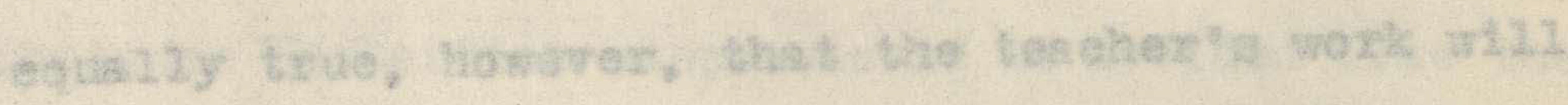

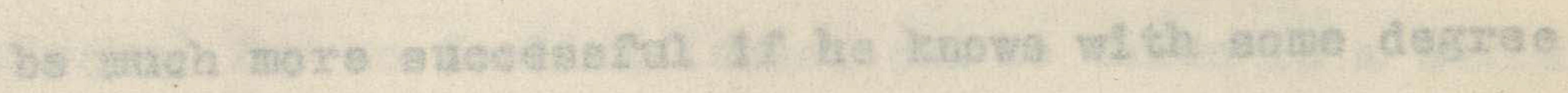

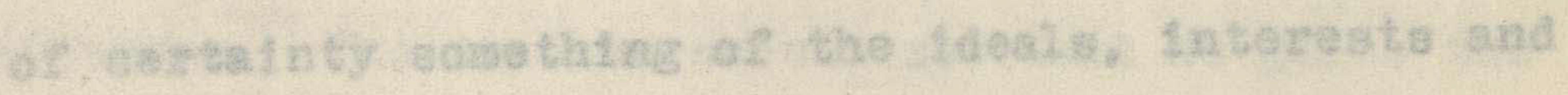

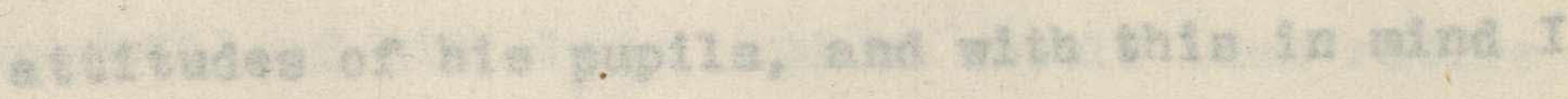

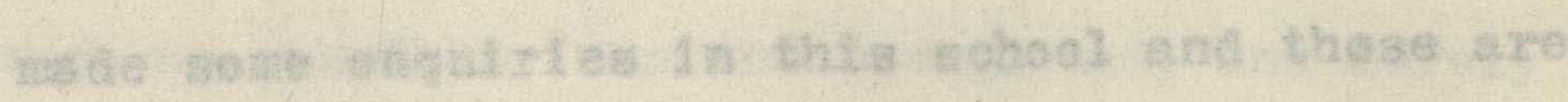

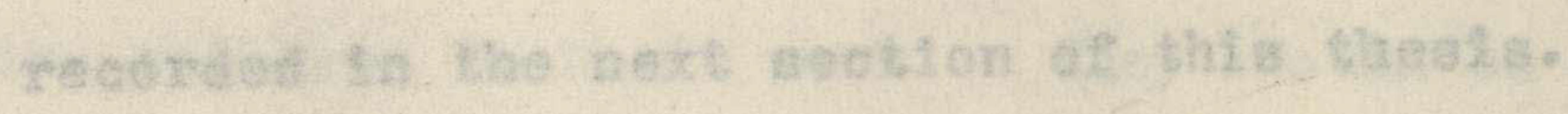




\section{ITSSONS IN APPRECIATION.}

taviling I have discovered that it is useless for a teacher to judge what pictures should be presented to a mixed form merely by studying the individual tastes of each child, and many of my most successful lessons have been those dealing with pictures for which individual children had previously no particular preferences. The tastes and ideals of a mixed class are by no means a composite of the tastes each of girl and boy in that class, for if lessons in appreciation are to be successful they must have a high group value. It is true that appreciating is an individual process, but in the earlier stages of appreciation at least. children for instance make their criticisms much more successfully and happily if they feel that they have the backing of social opinion. It is equally true, however, that the teacher's work will be much more successful if he knows with some degree of certainty something of the ideals, interests and attitudes of his pupils, and with this in mind $I$ made some enquiries in this school and these are recorded in the next section of this thesis.

The lesson in appreciation of pictures is a above everything a "feeling" lesson. Now it is 
very difficult for anyone to reproduce an emotion at wi11, but the lesson in appreciation is all "humbug" and hypocrisy unless emotion is actually there. In dealing with children's emotions it is possible for the teacher through ignorance to produce disast $\phi r o u s$ results without meaning to, and it is absolutely necessary that th teacher of art appreciation should not only know his subject but also know well the characteristics of the emotional life of his pupils at each stage in their psychological development. There is a very real danger in the teacher ignorantly tinkering with the emotions of his pupils or in his arousing stronger emotions. The teacher's own emotional life must be developed, cultivated and controlled before he ever approaches a class and he must place high value on his subject as well as upon the principles by which his pupils may be taught to really like that subject. The procedure in appreciation lessons must never be formal for instance Herbartian steps should be avolded like the plague) for no feeling lesson can be taken in a series of steps. The teacher should seebthat he gains the goodwill of his class, and he should then retire as much as possible into the background, and merely guide the children in their work. They should be made to feel that it is they who are doing the appreciating. Too easy have I found it to be for the teacher, thoroughly appreciative of a picture, 
to rhapsodize, only to find his pupils tolerantly out of sympathy and touch with him.

The teacher's guidance, however, is still a necessary part of the lesson. Children are all born with an instinctive desire for beauty but they must be taught appreciation because unfortunately without guidance they often come to like tawdry things, to prefer tinsel to gold. Beauty in art rarely lies on the surface. It has to be investigated, and effort is required before that beauty can be fully enfoyed. It is this investigation or appreciation that we must teach. It is beyond the province of this thesis to enter into a discussion as to the relative values of the factors upon which the beauty of a work of art depends, but the teacher of appreciation must lead his pupils to an insight of those values, and no picture should ever be presented which is beyond their grasp. For instance $I$ have found that it is natural for the third form pupil to enjoy lavely pictures, pictures telling stories. If pictures of the more thoughtful type are presented to him, they should be as simple as possible and suited to his psychological stage of development and they should be always before the child until absolute familiarity is acquired. Again if the picture has a complexity of structure and a loftiness of conception such as belong only to the finest achievements of art, it 
should be observed without definite attention being drawn to it unt11 a certain degree of familiarity is established. The pleture should not be analysed and synthetized until it is possibie for the child to gain

a clear 1 dea of 1 ts complete design and content. The chila should also be encouraged to express in writing or drawing or in simple speech, the things which are suggested by the mood, message and design of the pictures, for this will be of benefit to him in many ways. It calls fox observation and attention, for sympathetic response, quietness and self-control imagination, recognition of form and order and psychological sequence, and it will develop his technique of self-expression through word or art, and give him a real understanding of the great function of the arts. For what, when all is said and done, is this great function? It is to $11 \mathrm{ft}$ man from the plane of the creature to that of the creator; and IIfe can offer no greater satisfaction than the sense of emaneipation which this confers upon young and old al1ke.

These remaxks would be incomplete without some observations of the effects of the presence of aplay. girls and boys together in the classroom. I have found that in general girls act and speak far more naturally in mixed classes, particularly in lower forms, than do boys. Poys are inclined to be restrained and 
cautious about their opinions in the presence of girls. In no sense however, do they feel inferior to the girls - Indeed the tendency seems to. be for a vast feeling of superiority to be experienced by the boys over whatever the girls say, do or like. To a picture that is $11 \mathrm{ked}$ by the girls as a group, I have often found the boys' attitude one of professed indifference. This attitude is frequently not present either when the picture is presented to the individual in private, or when it is presented to the boys in a classroom apart, yet definite enough in a mixed class. In mixed classes too, I have found it harder to arouse and hold the attention of the pupils and to direct the attention than it is in a form of boys or a form of girls. It is also more difficult to judge the amount and value of the appreciation that is being done, but I am inclined to think that in the apper. forms at least, the task of the teacher of art appreciation is easier than in separated classes. Many boys of 16 and 17 years and even some of 15 years I have found more responsive in a mixed class than otherwise and this not from any desire of self-display. 


\section{CHILDRWN'S TATALS.}

The average child attending high school lacks that time for leisure which is so desirable for the appreciation not only of pletures but also of other fine things of lafe. Kearly $63 \%$ of the boys in this school work el ther before or after school and $11 \%$ work at both times. From infomation given voluntarily and anonymously by the boys of two third forms, one fourth form and one fifth form I found that the average amount of money that each has to spend each week is two shillings and three pence. Ten boys were earning weekly sums varying between $17 \mathrm{~s}$ 6d. and 22s. 60.. but seven of these informed me that the largest part of this was given to their parents. The money is largely spent on "lollies" and on the talkies". $24 \%$ mentioned stamp-collecting, and only $5 \%$ spent their money on such hobbies as wireless. fretwork and cabinet making. It will perhaps be comforting to the art teacher to know that if good pictures can be introduced by some meens into the home and school. then these pictures will ultinately come to be preferred by those who have them constantly by them despite both the present "practlcal" outlook of the parents and the lack of lelsure of the chlldren. Txperiments described later show that this is so. of 425 pupils, $11 \%$ attend talking-plctures once a week, $38 \%$ once a fortnight, $5 \%$ about once 
every three weeks, $19 \%$ once every month, $22 \%$ attend approximately once every three months, and $2 \% 1$ ess frequently. I was surprised to find that 13 pupils (nearly $3 \%$ ) had either never attended a motion pleture theatre or had only once attended. The reasons lay apparently in the religious scruples of the parents, and I found that nearly all these 13 pupils were proud of their records. I do not give a full list of the favourite actors and actresses. The favourite types of pictures and the numbers who gave names of pictures are shown in Table A. It $_{0}$. It be seen that "adventure" holds the highest place in both the girls' and the Boys' 11sts. The picture of this type which was easily the most popular was "The Black Watch," a picture based on one of Talbot Mundy's books. The picture All Quiet on the Western Front" was the most popular war picture amongst the boys, 23 mentioning this as their favourite. The number of humorous pictures mentioned was only three netertheless 24 boys and 20 girls named one of these three pictures as the one they enjoyed most. It will be noticed that didactic pictures do not appeal a great deal to either girld or boys, and apparently neither do historical pictures. The chief reason of those who did choose this last type as their farourite was that the actor or actress had a high place in their esteem. Pictures of the musical comedy type in which 
there is a good deal of singing and dancing appealed more to the girls than to the boys, but detective pictures appealed more to the boys than to the girls. Modern love pictures appealed strongly to 28 girls, but this type is not mentioned by the boys at all. I found that by about one half of the children the picture was liked for the story contained in it. only 5 boys and 2 girls gave the critical type of reason - "the acting was clever", or "the production of this picture was outstandingly good" - as reasons for their choice. The others mainly gave as their reasons that " - - was acting in this picture and he is my favourite actor", I know that there is a huge passive body of opinion against children attending pictures. This is not the place to enter into a discussion of the effects of the "talkies" on the manners and morals of children, but in passing I must say that in my opinion a good deal of the matter considered as having evil effects upon children is entirely above their comprehension, and that the attitude of the children is not always one of imitation but of make belief. In so far as historical and other types of "talkies" make children really famillar with for example the habits, outlook and environment of peoples in past ages and in other lands, the teacher of art appreciation in the classroom should 
take cognizance of these pictures.

It is hard to get reliabie reavlts when attemptIng to judge children's Ideals simply by means of questionnaires as to favourite books, or 1 deal stories ox characters, partly because there are faghions in ohildrens books just as there are fashions in the reading of aduits, and pertly because children will nearly always give as their ideal sompthing that has appealed in the immediate past. Nevertheless in conjunetion with personal enquiries and observations certain general conclusioris may be made. Tebles $n_{0} 2,3$ and 4 , are sele explanatory and in the main coneirm observations and impressions made in the classroom as we11 as the results of personel enquiries. Boys Iike action adventure, sersation and even truculence. Girls appear to like emotional books, scenes ond thoughts. Boys like seience, history and travel, girls prefer novels, biographyand appear superfieially at least to appreciate poetry more than do boys. I have lound, however, that al though boys' cholee of poems is not so wide as is that of the girls that the desire for and appreciation of certain poems by boys is very real and intense. Women writers appeal more to girls, men writers more to boys. Girls read more fiction than do boys, and girls eare more for flneness in style, 111ustration and binding. They treat books better than fo boys, and are more amenable to 11 brary rules. Boys revel in practical jokes snd tales of wild escapades. In their 
tastes they appear to be more practical, vocational and even special. The interest of girls in romance is earlier, greater and continued longer than is that of the boys. Both girls and boys, however, appear to be equally definite in their demands for animal and bird books copiously illustreteds. The demand for books about pictures and for lives of the great painters has pleasingly grown since pictures have been studied in the elassrooms of this school.

The reasons for the cholce of the 1 deal occupation (Table $\mathrm{H}_{5}$ ) were classified in the same way as were the reasons given in the questionnaire to the primary schools (vide Appendix) and Table $N_{0} 6$ showing the resul ts needs no further explanation. 


\section{COLOUR PREFERENOES}

Three hundred and fifty-nine pupils (180 boys and $179 \mathrm{girls)}$ were asked to place in order of preference red, blue, yellow, green, violet, black, white, and to give reasons for favouring most the first colour in their 11sts, and for favouring least the last colour in their 11sts. One boy said that he was unable to make a list as he said "A11 colours are the same to me - just being colours. I favour none and dislike none, except black."

The average order was as follows:-

\section{Boys}

Blue

Green

Violet

Yellow

Red

White

Black

\section{Girls}

Blue

Green

Red

Yellow

V1olet

White

Bla ok

This result was in part verified by comparing colours on lines set out in Seashore's "Elementary Bxperiments in Psychology" - Pages 191 to 204, and eamplos of the eolours used are given in table

It was possible to test only 138 pup1ls by this method, but the indications were that the results would be in each ease the same, blue, green, being the most favoured colours, then red, yellow and violet, and lastly white and black.

The similarity of the boys' and girls' Iists is very striking, but it will be noticed that violet holds 
a much higher place in the boys' 1 ist than in the girls' and that the boys prefer yellow to red, but that the opposite is the ease with the girls. This is probably due to the fact that the sohool is divided into four houses for games, and the house colours are blue, green, violet and yellow. The factor of preference for the house colour was more definite amongst the boys than amongst the girls, and this appears to be due to the fact that girls are influenced more in making their cholce of colour by the suitability for dress or complexion than by the house colour.

The age groups of the children who named their favourite colours are shown in Tables 4,8 and 9 , and the numbers of each age group of those who named the coloux they favoured least are shown in Tables 10, 11 and 12.

The colours least favoured are:

$$
\begin{aligned}
& \text { Boys } \\
& \text { 1. Black } \\
& \text { 2. Yellow } \\
& \text { 3. White } \\
& \text { 4. Violet) } \\
& \text { Red } \\
& \text { 6. Blue } \\
& \text { Green }
\end{aligned}
$$

\section{Girls}

1. Black

2. Yellow

3. Violet

4. Red

5. Blue

6. Green) White)

Black is easily the colour most disliked by both girls and boys, and the number of pupils who voted gainst this colour is greater than the total number of pupils who disliked other colours most. Yellow is also greatly disliked.

The reasons for the choice of the favoured colours 
and for the disliking of other colouxs classlfled according to the fuagnents on the afferent espocts of colour fall Into the Ioux well-known groups, and tebles 13 to 22 . sumnerize these reasons. I ixnd several reasons difficult to olessify from the writton statemonts and in these cases personal questioning was necesary before the type could be placed.

A. Objeotive 3ype. The reasons of 18 boys and $29 \mathrm{gfrls}$ for favouring eertain eolours were judgments upon the qualities of the coloux, and the reasons of 26 boys and 68 girls for disliking eolours were judgments of the same type.

The sollowing ere typiosi :-

(1) "Blue is my favourlte colour besause it is avoh a pure coloux. Al though you often see an ugly green or a xed, it is seldon jou see sa ugly blue." (cirl sged 14+)

(2) "I 2 lke rod begt beeause it is a bright colour." $(61 x 2$ sged $12+)$

(3) "Yellow is the best colovr because it is not too bxight. It is sort and xestiful to the ogos snd does thot lede." (a1r2 aged $13+$ )

(4) "Green pleases mo bost because it is easy to $100 \mathrm{k}$ at. Red mekes your eyes sche, but green never does." (Boy agod $11+$ )

(5) "I 2ike violot best beause it is riols in coloux and blends we11 with other colouxs."

(6) "I pleced bleck last becsuse it looks dirty, and is too henvy." (Boy aged 13+)

(7) "I dislike yellow beoause it is too thin, but dark yellows are too bright." (Girl aged 16+)

(8) "Blaok is too dw12." (o1 21 eged 12+)

These children epperent1y do not adopt so muich an onotional. attitude to colouxs as an aloof attitude of oritiolan. They have in mind a standard by whioh they "measured" colours, and this standard I have found 
ocossions.1y hinders thom in the ix appredati on of coloured pletures.

Red, Jellow or violet were disllked by 7 gixle and. by 8 boys because these colours were considered to be "too bright" while 22 bogs and 19 girls preferred these colouxs for Just the opposite reason. 9 girls and 6 boye preferred blue, grean or yellow becsuse these colowrs were "sott" "rostiful to the eyee" "xich", "clear" or "pure", while one boy aged 11 - prelerwed black becanse 1 t "makes e. good beckgrowad", and one glxl aged 13- prefexred yollow becanse "lt does not Iade".

other reasons mentioned for favouring coloux least

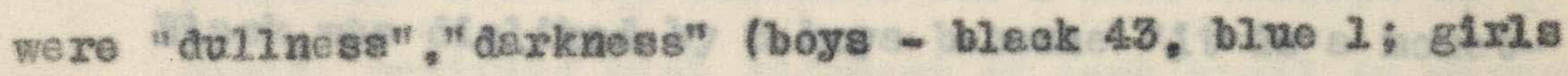
black 6); "10oks alrty" (girls-black 8; boys-black 5 , v101et 1), "too xlog", "too heavy", "too 11ght" (boysviolet 2; girls violet 2, black 1 , yellow 1 ).

\section{B. Physiological Tyee.}

Chilaren often prefer or alslike colours becanse of the alrect physiologleal effect on them. The ressons of 52 boys and 20 girls for favouring entaln coloux were Judgments of this type as a.1so were the reasons of 25 boys and 15 gtr.1 Ior disl1kIng other colours.

the warmth of redness was mentioned by 4 girls and 3 boys; the freanese and restiviness of green to tho eyes wes mentioned by $5 \mathrm{~g} 1 \times 1 \mathrm{a}$ and 17 boys; the freshness of yellow appealed to 5 glxls and $\eta$ boys; 12 boys and 5 girls preferred green, blue or yellow because they were oool 
one girl preferred violet becuse she considered It to be a goothing colour and three boys preferred green fur the same reason.

On the other hand yellow was the colour least preferred by chlldren who gave reasons based on this aspect of coloux - II boys and six gixls disliked yellow because it mede them"feel siok" 5 girls and 4 boys alse disliked yellow becanse they said "it hurts the eyes", and 4 boys and 2 girls disliked red for this reason too. 2 boys disliked violet as they said it was a"tiring" colour, and one girl disliked violet becans"it is a painful colour". Black was disliked by 3 boys because "1t is a monotonous colour", by another boy who said"its always draws the heat". Red was disliked by one girl for a similar reason. She said "Red is the colour I like least of all because it always makes me feel hot"

Reference to Tables 20 and 81 will show that the physiologieal type of judgment is the second commonest type amongst the boys, but that this type Is least common anongat the girls. with girls the objective type of Judgment renks seoond.

C. Associetive Type. This typo of juagment is the Ioading type for both boys and girls, and it is rather striking thet (Tables 20 snd sf) the numbers for girls and boys are the seme. The judgments of 
74 boys and of 79 girls for Lavouring coxtein colours wexe judgmonts made because the pleasingness of those colours lay is thinge essooiated with thon.

The reasons of 40 boys and of 34 girls for disliking the coivurg were judgments of the seme type. Mr $\mathrm{E} . B u l l o u g h$ in an article "The pareeptive Problom in the Aesthetic Appreolation of Single Colours" in the British Jowrnal. of 8eyohology (Volume II) states the to he found the essociative type of judgment less comno:? than the physiologioal type, but py own investigetions in this sohool do not eorroborate thie Iinding. Great asre has been taken that the elassification of Judgmonts has been accurate for I have fexcept in 5 c8ses) verifled each fuagment of esch pupi工. in person. 35 girls chose various colours (Blue I8, Green I2, Yell ow I, white I, Rea 3) becavge these colours "snited" then sor dress. Th1s reason was not mentloned by the boys, sl thongh one boy(who gave his snswer undor 8. nom-de-plune) aged I7, chose blve as his sevouxite colour because "the $\mathrm{g}^{5} \mathrm{xl}$ for whom I have a very doep regerd has blue eyos and uses this eclour a good deal". This boy wos not, hovevor, on his own in liking a colour best for this roeson. Two girls, one aged IS and tho other IV,(they did not uge nom-de-plumes) sald that they preferred blue, one because she sald "1t suitus my bean" and the othex becunse she seid"my best boy is in 3.1ve Iouse" * As hes alreedy been mentioned the sohool is divided for ganes in four houges, the house colours 
being blue, yellow, green and violet, and 58 boys and 20 girls mentioned as their reason for preferring their favourite coloux, that it"is the coloux of the best house",or, I belong to ......... house" . The numbers are fairly eventy distributed between the four houses and in a.1 cases the girls and boys aged I3 more than in any other age group have given this reason. It w11l be noticed that the numbers of boys who gave the House colour is noarly 3 times that of the girls, but this does not indioate that the girls have less "team spirit" than the boys. The suitability of a colour for dress plays a bigger part in determinIng the average girls' choice, however, than does the colour of the house.

8 girls disliked jellow, red or black because of the faot that these colours did not suit their complexlons, but one girl disliked yellow because "it is the colour of the house I dislike", and one girl disliked green "because it is the colour of green house. The boys are very bostful". On the other hand, 4 girls and 2 boys preferred green to any other colour because this is "Ireland"s coloux", but 2 boys disliked green for exactly the same reason, and one girl disliked yellow because "it is the colour of the Orengemen". Blue was the favourlte colour of two boys, one because "It is sootland's colour", the other because "it is the colour of the Havelook North Football Team". 
Blue and groon wore the favourite colours of 7 sign

by boys and I2 girls who gave as reasone that these vere "nature's colours". These colours reminded them of the sea, the sky,green paddocks, or of favourite 1lowers. For instanee one girl aged 13 years 4 months sags: "I I hate ved. Ink" . leietlike blue best becouse it rominds me of so meny beeutiful things. There is the blve of the sea, the blue sky, blue cornilowers, and the blue that we see in a peacock's ta11." And a boy aged 14 - says "Blue, becazso I 1 ike looking at tho sky and horing the skylarks sing" . Other reasone for preferring blue are given by one boy who says:"It reminds me of the saints", snd by two other boys and two girls who say that "Blue olothes don't show the dirt". Two girls, both 13-years of age sald that they like white best because $1 t$ is worn by nurses who aze clean and healthy."

Black was dislikod most by 19 girls snd 23 boys because it reminded of death, funerals and mourners. Yellow was unpopu?ar with 1 girl because yellow reminded her of the chineso, with another 2 boys who disliked it becauge it revinded them of yellow jeundice, and with another 2 boys who sald "it is a "Cheesy" oolour."

Wite was least fevoured by boys who found white olothes difficult to koep olean and by another 4 bozs who sald it reminded them of hospitals. Anothor boy sald thet he disliked white beause "I see too much of 1t. Hy Iather is a barber." if the 18oojettppreciatiterest Id his 1a, or 10 and itwe1gh lorget who exling a lause 1 ts Ixd more that the reo of tween 
4 boys aisliked red beceuse they said "it is the sign of danger and blood", and red was lesst fevoured by one 11 ttle boy aged II years 4 months who sala" I hate the colour because I em always ruling of with red Ink" . with regara to the aesthetic value of associetIons in the appreoistion of pietures, I en inclined. Iron my experinents to think that this depends upon the associations themselvos. Mr B.Bullough places this type of judgment or person very high in the stege of aesthetic development. To a certain extent the kind of associations are determined by the experiences of the child, but I am unable to belleve that oolour associatIons alone are of very great importance in the appreolatfon of plotures. The ohllas outlook and his interest in the subjeet of the pleture on the one hand, and his apprecietion of such matters as the purpose, mood, or messege of the artist, technique employed, balence and harmony on the other, more often than not far outwelgh the colour preferenee alone. I w111 not soon lorget Ittle Hae G....... aged I3 years, in Form III, who exclaimed whon he was shovn Verneer's "A GIrl Reading a Letter"; "well I have always disliked green because Its Irish, but that curtain is great". I am thereforo nore Inelined to agree with Ir Bullough's contention that the value of these assoclations depends upon"the degree of fusion which can be reached by the individusi between 
the coloux impreseion and the associated content"* D. Character Type.

and I Teble 22 shows that only twenty Lour pupils besed thoir judgnents in giving reesone both for fevouring most a certain colour and for dis11king least another colour upon the cherreter egpoet of the colours. The reasone of I4 boys and. I3 girls for fevouring most eortaln colours, and of 36 boyis and 37 girls for favouring lest other colours, woro reesons of this type. The following are typlcel:(I) "BIue Is my Levourite colour because it is unobtrusive yot snlu of ahereator" (Boy agod IEH).

(2) "Yeulow becouse it is oheerful and heppy" (Boy aged I3t).

(2) "I aislike black begause it is dopressing and gloong".

(4) " Yellow is too week and sentimental to bo nico". (Boy aged $\mathrm{Int}$ )

(5) " I 21ke red bectuse it is full of $1110^{\prime \prime}$. wably ( GIXI aged I3H).

(6) "fl thite is the best colour beceuse it is neat" ( Q1xl agea 144 .

(7) 1 dislike violet because it shouts at you". ( G1x2 aged $16+$.

Green was favoured by 4 gixls and four boys bocsuse It was considered to be a happy or oheerful coloux and yellow was fevouxed by 2 girls end I boy for' the 
same reason. Blue wes popular w1th 4 boys and I Girl because "It is a quiet colour", by 2 girls and I boy because " it is a delicate colour", and by one girl and one boy because blue was "simple", or, "gentle". Red was considered "Ixiendly", "expressive", "full of 11fe",by two girls and one boy, while blue was considered to be "full of character"by one boy and violet was considered to have "depth of character" by one girl.

On the other hand black was disliked by 32 boys and $26 \mathrm{girls}$ becanse 1 t was thought to be "gad", "disma1" "gloomy", "movrnful," "prose10",UninterestIng", "miserable", "grim", " doleful", "unhappy", "inexpreasive", "depressing", or "1:fezess", and one boy disliked black because it is"uncenny and mysterious: White was disliked by I $g 1 x l$ and $I$ boy beeanse "It is an uninteresting and boring colour", and blue by another boy who said " blue is always making itself out to be bettex than it real1y is". Yellow was thought "weak and sentimental", by I boy and I. gixl, while violet (2) and red (I) were considered to be "agressive" 1 oud" or "shouting at you", colourg by 3 other girls. Violet was also disliked by 2 girle who applied the epithets "gloomy" and"shlety" to this colour. The children of this type I. found to be generally fex more appreolative of colours then either the phyalologiosi or the objective types. The process 
of "erapathy" or "projecting thenselves" and holding themselves in the colours and in pletures was much readiex with these pupils, and in fect they always folt a deIinite and lively sympethy with them. Here again it was necessary for me to verify by personal onquiry the writion statemente of several of the pup11s. It was doubtful sometimes, for Instance, whe ther the adjeotIve "warm and IrIendiy" moent that the pupil lelt,on perceiving the colour, warm and Ixiendiy, (In which case his Judgment was on the physiological aspect of the coloux) or whether the coloux 1 tself wes waxn and Iriendiy. Only two pupils of those interviewed thought it impose1ble sor a colour to have "charsoters" and these two had meant judgments of the objective type. Yellow was sald by one boy to be a "weak" coloux, but it was found thet he wes making a statement on the objective aspeot of jollow, and another boy when he gasd that violet was "undecided" meant that since red and blue are mixed by the artist to make violet ho considered violet to be "not pure but mixed" and the colour wes disagreeable to him lor this reason. 
A comparison of Tables 13, 14, 16 and 14 w111 show that pupils often gave judgments which belonged to one group for favouring most certain colours and to another for favouring least other colours. Children do not necessarily belong to one of the four types lor many are intermediate types. The numbers in each age group seem to indicate that children's extimate of colours does depend upon the stage of psychological development, but the numbers are too small to draw any safe conelusions. However, my own impression, tw not based on figures but on several years work in the classroom is that this is so. The types are not distinot and I have therefore combined all the judgments in Table 21 , and I find that the proportions of each pure type is approximately the same. The numbers of pupils who made judgments of one type only in choosing the most favoured and least favoured colours are shown in Mable 22 Less than one half of the children belong turely to one type, and the percentages of these are approximately as follows:-

(a) Boys: Objective : $21 \%$

Physiological : $79 \%$

Associative : $46 \%$

Character : $14 \%$

(b) Girls Objective : $32 \%$

Physiological $18 \%$

Associative : $36 \%$

Character : $14 \%$ 
(f)

\section{COLOUR PREYERENCES OF MAORI GHILDREM}

During the time that experiments were being made for this thesis, 16 Meroxi chilaren ( 10 boys and $6 \mathrm{gixls}$ ) have sttended this solfool. Only 5 of the boys and 4 of tho girls were 1 ful-blooded Haoris. Inveotigations ss to their colour preferences were proceeded with on the same Iines as In the previous section, and the average order of preferenee wes found to be es Lollows:-
Red
Violet
Green
White
BIsek
Yellow
Blne

The following atriking facts are noticeable when this 11 st is compared with those given on pages 25 and 26.

(1) Red holds a much higher place in the estinate of Maoris than it does in the estimate of white childron.

(2) hile green is fairly high in all three 1ists, blue drops from I1rst plave for white children to lagt place for Haoris.

(3) Violet appeals far more to Maorl ohlldren.

(4) White snd bleok are not so disliked by these native children as jellow is, el though jellow is favoured more by whito children than elther white or black.

(5) In a.1 cases white is preferred to black.

The numbers who chose certain colours as their fevorites are as follows:-

Red 8 Violet 4 Green 2 Yellow 1 BIne 1. 
while the numbers who disliked other colours are as fol1 ows :-

\section{Blue 7 Yellow 5 Black 3 Green 1}

The reasons for the cholce of colours were claseifled ละ follows :-

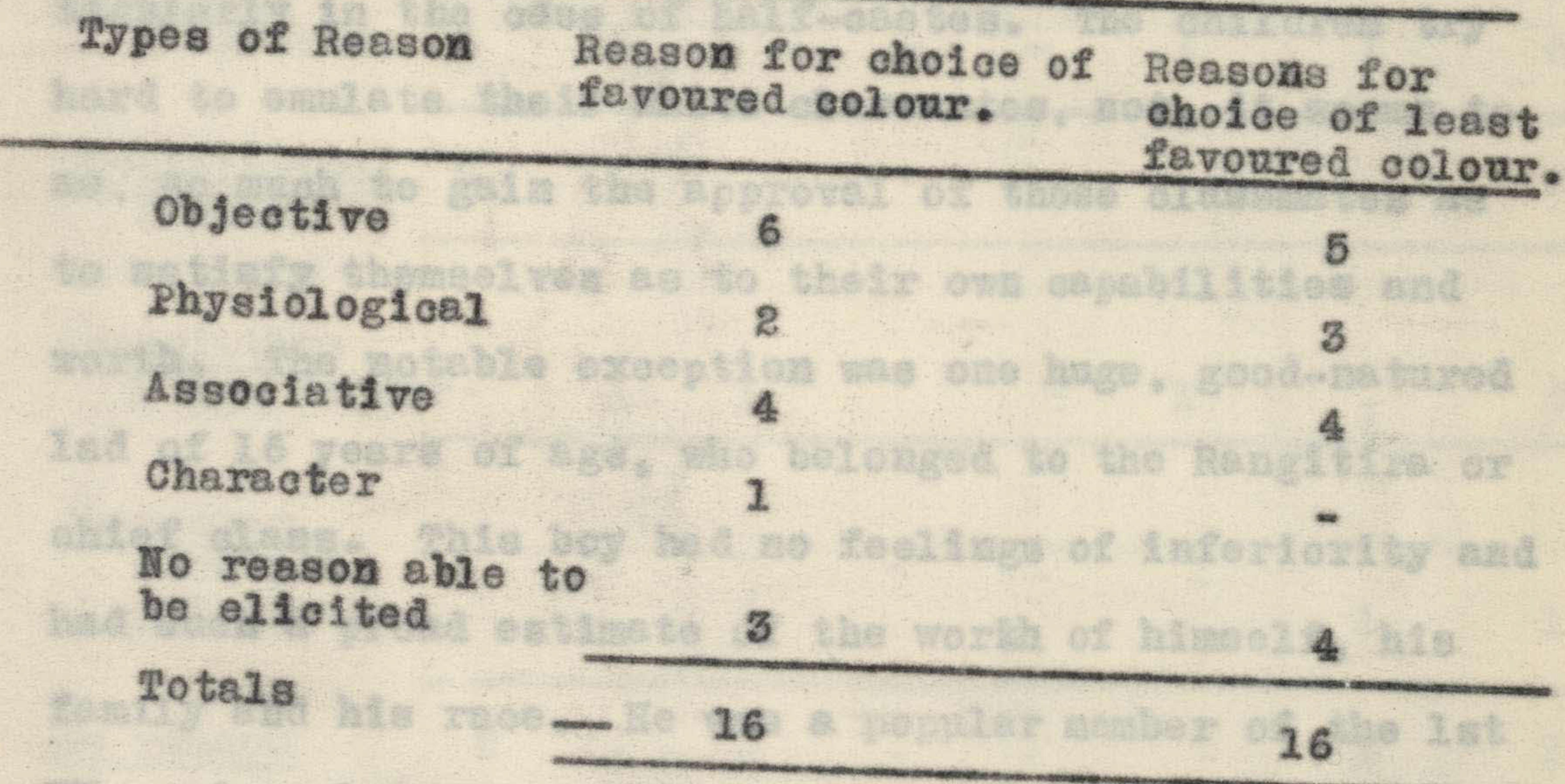

These reasons were in all ases investigated both by written statements and personal enquiries in privete. The numbers who gave written reasons wore very few (boys, for 11king a colour most 4, favouring a colour least 4; girls, for 1 iking a colour most 2, for favouring a colour lesst 3) and I found the children who had not given reasons rather doubtf al about my purpose. Though I believe I managed to gain the confidence of each child, I was unable to elicit any reasoas from 3 pupils (1 boy and 2 girls) for choosing a favourite coloux, and from the same three and 1 other boy for favouring certain colourg 1east. Maori children are very shy, \& despite the apparent equal status of Pakeha \& Maori, are very 
sensitive to any implications that they are an inferior race to the European. This sensitiveness I have again and again notlced both in the football fleld and in the classroom. I believe the children bring this atitude of defence against such implications from their homes, partioularly in the case of half-castes. The children try hard to emulate their white classmates, not, it seems to me, so much to gain the approval of those olassmates as to satisfy themselves as to their own capabilities and worth. The notable exception was óne huge, good-natured lad of 16 years of age, who belonged to the Rangitire or chief class. This boy had no feelings of inferiority and had such a prond estimate of the worth of himself, his family and his race. He was a popular member of the 1 st $X V$, and a platoon sergeant in the oadet company, and the boys' attitude to him was always one of acceptance as an equal. His responses were always frank and open. His disposition was more clearly that of the extravert type than were those dispositions of the other Maorl children, but he was not as far as I could find a pure extravert. From the other 15 children I classifled as 3 extraverts and 5 introverts and it was difficult to say which type the remaining 7 belonged. The reasons for the cholce of colourg were as follows:- 


\section{Eor favouring colours nost}

Red Yellow Blue Black white Green Violet Toteli

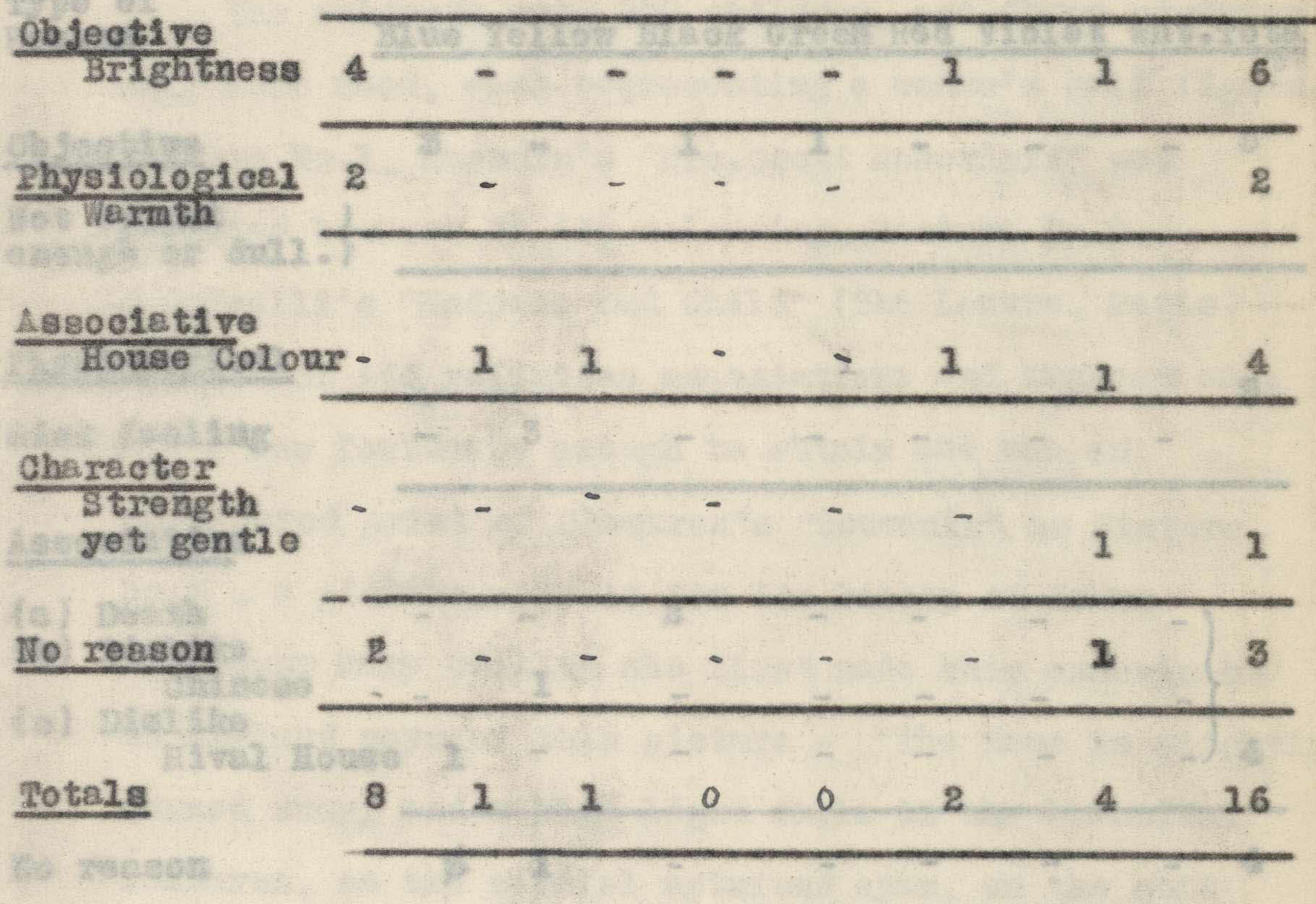


212

\section{BOR FAVOURTHG COLOIRES LEAST}

Iype of

Reason

Blue Yellow Black Green Red Violet int. 20 ta:

Objeative

$3-1-1-1-5$

INot bright enough or dull.)

Physiologioal

siek reeling

Associative

(a) Desth

(b) Dislike

(a) Disilke

Chinese

RIval House

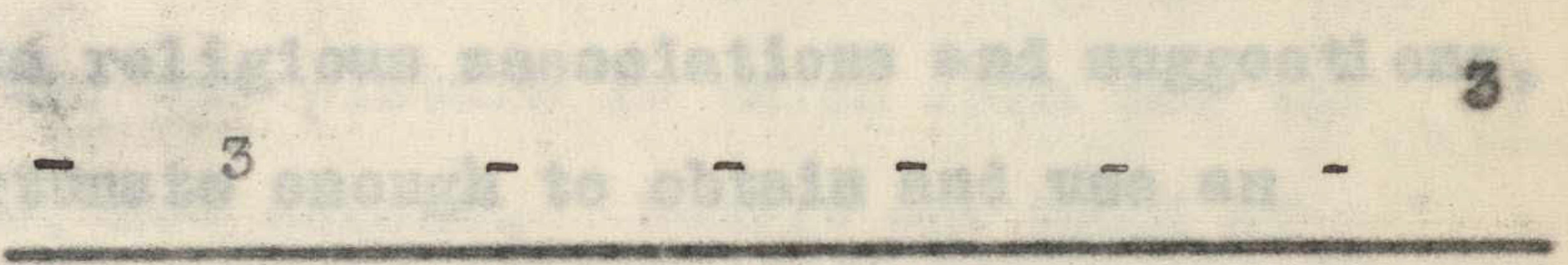$$
\text { IIo reason }
$$

Totals

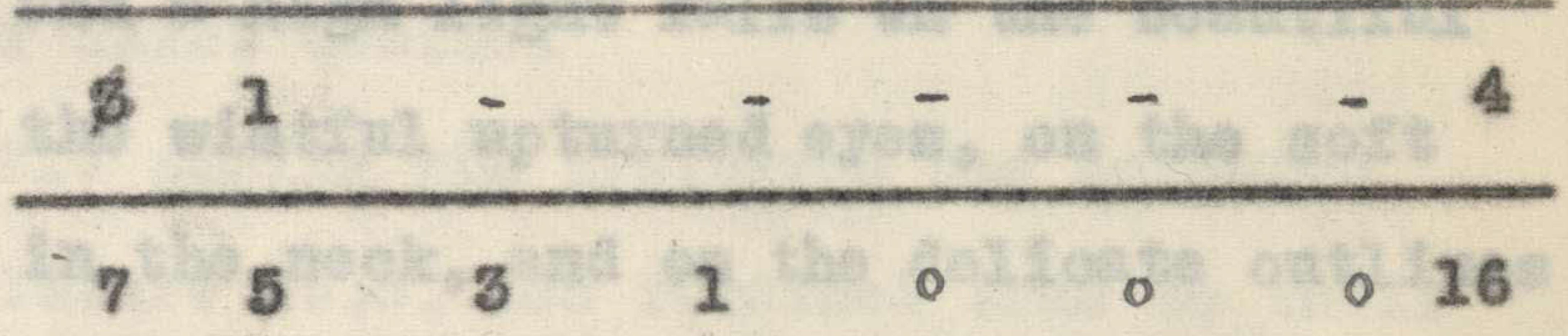


This experiment to find the preforences of children was earried out in the seme vey as is explained in Velentino's "Paychology of Boauty" (Page 74)

The subjeots were 278 children, snd three plotures ohly wore used, each ropregenting a woman's hall I1gure. Pleture No.1, Raeburn's "Mrs.Seott Honorielf" was selected becane of 1 ts colouxing, I loture No.2, Bottiee111's "Iledonne and Child" (The Louvro, Paris) because of 1 ts religious assoeistions and suggesti ons, and I was fortunste onough to obtain and use an uncoloured print of Chantron's "Souvenix" as Pleture No.3 a pioture notable for 1 ts beanty of form? Professor Mary Calkins who flrst made this experiment in Ingland says of this pieture - "Tho face is slightly turnod away, and a high 1ight folls on the beautiful featuros, on the wistful. upturned eyes, on the soft hair knotted in the neok, and on the delicste outlines of the shovlders, arms and brok, from which the garment has fallen awey".

Plotures 10.1 and 10.3 were shown together to each Individuel child end ho or she was asked which ploture was preferred. The pioture selected was thon prosented again with P1oture N0.2, and again each ohild wag asked which he proferred. The reavl to are given in Tablo $\lambda_{0} 23$. 
It will be seon that colour plags a very large part in detexmining the oholee of childron for piotures, and that this factor is of importance through al1 atages of growth, though the rolative. percenteges of pap11s who prefer tho coloured pleture Is smeliex in the older age groups. The number who preforred Ploture $\mathbb{N 0 . 3}$ to Pleture $\mathbb{N 0 . 2}$ is small in tho asse of the younger children but inoreases fairly uniformiy unt11 of the pup11s aged 17 years, 4 out of 10 ohose the pleture in which form wes the dominant note, not colour. Mearly one half ol these pup11s, hovever, transforred "their allegisnee"

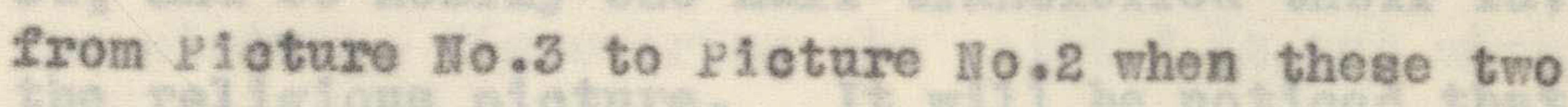
pioturee were afterwards shown to them, though the tendeney appears to be for the oldex pupils to remain true to thelx flrst cholee.

Of the 217 pup11s who preferred the coloured pieture to p1eture $10.3,188$ remeined true to the ir flrst cholce, but 29 changed over to P1oture I0.2 whon these two were presented together. The number of pup11s who are thus apparentiy definitely Influenced In the Ir choloe by religions assoelations id surpxisingly sma11, end the inference irom the IIgures geems to be that the religlous motive Increases al1ghtiy in importanco amongst the older pup11s. hile this lost inference agrees with my own impressIons gelned in a number of yeers' observation of 
children, I am inolined to think that this motive is much atronger than the figures seem to indicate, especially in the ease of pupils of more tender years. I feel thet factors other than those sought to be measured in this expeximent have influenced the choice of the pupils.

In the third group, however, I think the Iigures give a fairly sound indioation of the prinoiple being discussed. Pieture No 2 when presented with Picture No 3 to those pupils who had chosen this latter picture in case (a) was preferred by 24 pupils out of 5I, and so nearly one half translerred their favour to the religions picture. It will be noticed thet a bigger proportion of the older papils remained true to their choice of $\mathrm{Picture}$ No 3 , and if the numbers were lerger this wowld seem to indicate that older pupils are able more truly to appreciate the "more remote" aspects of a pioture than are the younger ones. I did notrecord the reasons given for each preference, (they were made verbally) but the number of pupils who in the reasons made any actual references to beauty of form wert very sma11, even amongst theolder pupi1s.

- .. These experiments indicate clearly the real need for training in appreciation that exists at the present time. True appreciation connotes intelligent understanding not merely enjoyment. Gorrect values 
are placed when a ploture is really apprecleted and this is impossible for ohilaren unleas they have 2 this is imposesible for children uniess they have a proper underetending of the ploture. children mey gxeatly enjoy something which is intxinsically worth1ess, or a mere shan, or even something which is bad for them. Ho one can appreciate anything properly by trylag to view it from the outside only, unless that is the sole purpose for which it is intended. A consideration of the exterior aspeot of a painting Its colours, curvo, mass, architectural design and so forth - Is not enough, nor is the mere consideration of say the 1 ines that are employed and how the parts are bullt up. Dolving into history and purpose of the pleture, discovering who painted it and when, whether he meant 1 t for ohwroh or palace, ext gellery or private dwel11ng, to what century and countxy it belongs - d1ecussion of these things in the classroom, wh110 it tovehes the human aspeet of the pioture, wi11 atil1 not roech the intimate knowledge of the painting itself which is necessary for eppreatetion. The ultimate origin of painting is in the human Impulse to express the emotions in a controlled and retrospect fashion. Children asnnot rightly appreolate a pioture until they are able to leel sympathetie response to 1 ts emotional and imaginative content. Therefore to trein the child in appreciation of piotures our first step must often be to lead him awny Iran Judging piotures merely by the exteriox 
aspects of colour, form and immediate associations, yins and oultivate in him the emotional and imaginatave response. As he is a ohild we nust not expeot him to respond excopt in the sphere of those emotions and imginings that are in line with the particular stege of his peyohological development, and these remarks do apply just as much to those pletures of the ertist in which the technique and skill of the artist aro part, as it were, of the amotional content of the ploture itself.

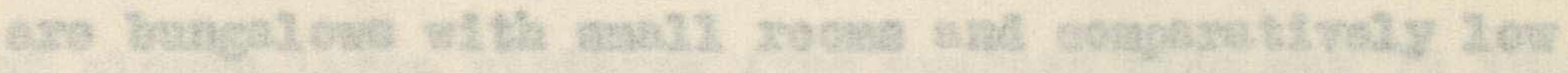

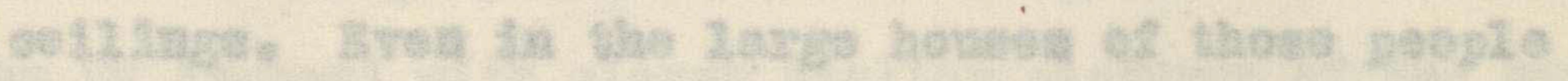

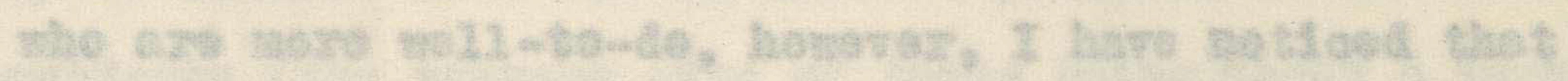

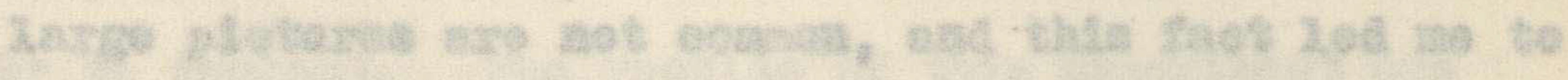

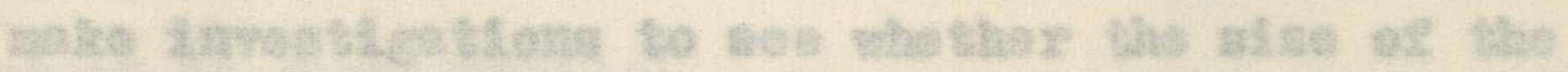

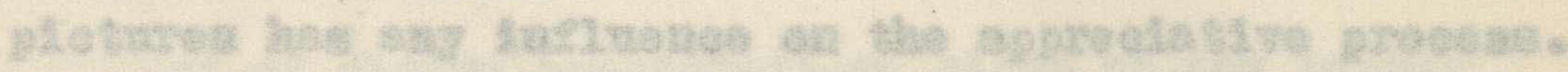

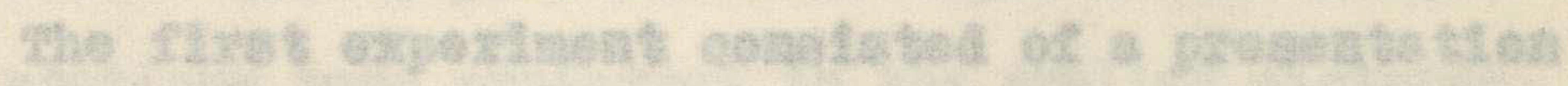

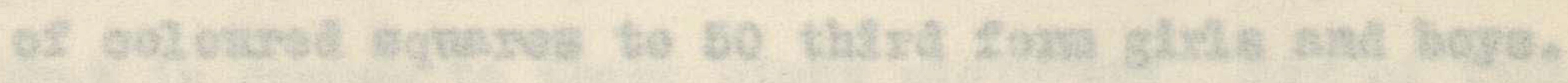

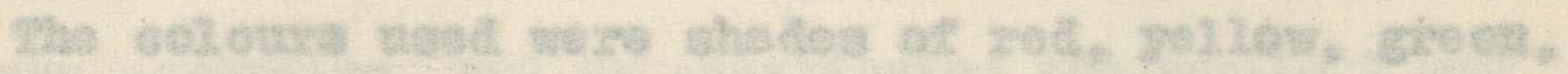

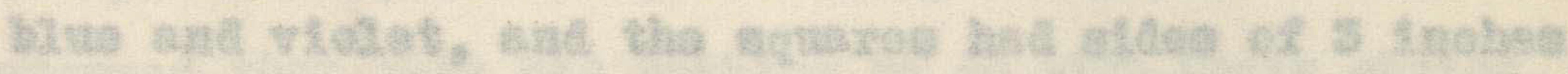

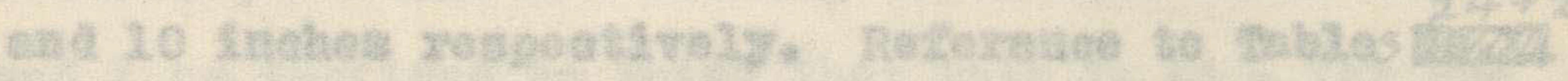

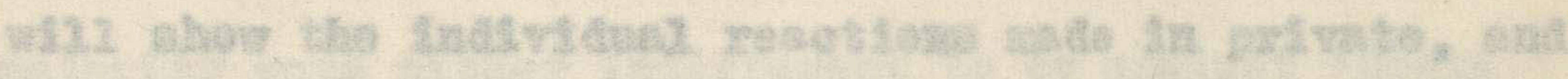

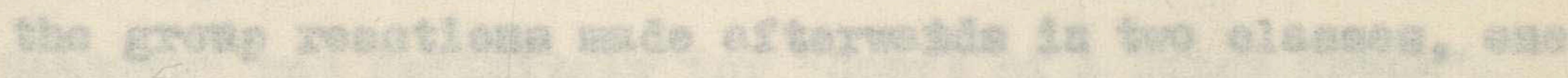

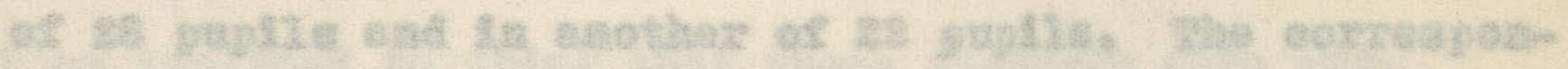

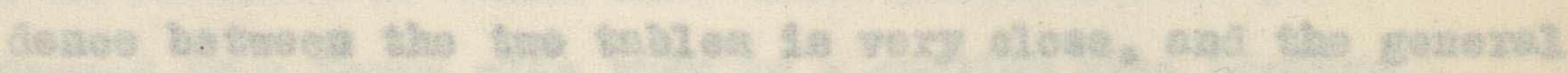

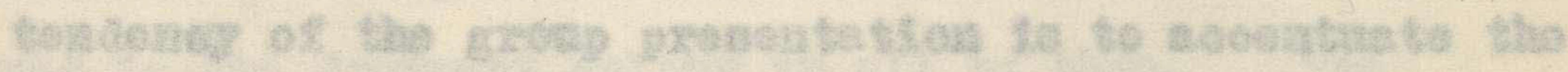


IHELUSWCE OP THE SIZS OP PICIURES

In the magority of the homes I have visited I have noticed that the pictures wore noarly always quite smell. In some homes one does see large pletures but the magority of the pictures are not nsualiy greater in size than about 15 inches by 20 inches. The ohleI rossons for this fact are probably IIrstly that lexge plotures are comparetively expensive, and secondy thet the majority of houses in Now zealand ere bungalows with small rooms and comparatively $10 \mathrm{w}$ ce11 ings. Jven in the largo houses of those people who are more we11-to-do, however, I have noticed that large plotures are not connon, and this lact lod me to make Investigations to see whether the size of the plotures hes any insluence on the appreclative process. The first experiment consisted of a presentation of coloured squares to 50 third form girls and boys. The colours nsed were shades of red, yellow, green, blue and violet, and the squxres had sides of 3 Inches and 10 inches respectively. Reforence to gables remp w111 show the Individual reactions mode in private, and the group rosotions nade afterwated in two alasses, ono of 28 pup1ls and in another of 22 pup11s. The correspondenee between the two tables is very olose, and the general tendency of the group presentation is to sccentrate the tendeneios revealed by the individuel resotions. In 
general these tables show that excluding red and Prussien blue, colours were preforred in amaller areas than in 1arger areas. In the case of red and lxussian blue, however, the larger areas wore in all lour cases definitely preferred. This seoms also to be the csge w1th 11ght green, but peacock green is certainiy preferred in meller areas than in 1arge onos. Whis proferenee for smaller areas it more marked with regard to 11ght shades than with regard to dark shades. The second experiment consisted of a presentation of eleven lergo pletures (tho average ฮ1ze was 19 inches by 27 inches) with eleven smaller piotures of the same gubjeots (the average size of the ae being about 5 inches by $\eta_{\frac{2}{2}}$ inohes). The results of this oxperiment are shown in table mage 26.

Out of eleven presentations elght of the laxger presentatione were preferred to the gmaller pictures. What is common to those olght ploturea? $\$ 1 x$ of them exo portroits, but on questioning the pup1ls I was assured that this had nothing to do with their cholee, and I am inclined to think that this is so - for the majority were vither indifferent to or sgainst "Beata Bestrix" but definitely for "Court of \& Dutoh House". I ain Inolined to thini that these plotures were preferred in a large size than in a smaller size because red is the dominant colour in all of then. The previous experiment also suggests that this is the reason * 
The third experiment consisted of presentation of a serles of plotures, two or three different sizes of the same subject. The largest plotures are Irumed in the sohool and covered with mastic varnish, but the ehilaren had seen them only occasionolig owing to the fact that these plotures have been hung in the administretive part of the sohool buslaings. Iable 29 shows $n$ conolusively) thot medium sized pletures are preferred to the larger ones. The post cards were obtalned from the liedlel Soelety and sppealed grestly to the children, but this appeal dia not qpperent1y ineluenoe then when they were pronouncing judgment.

The fourth experiment consieted of a presentation of the pletures on the walls of the classrooms. These rooms are 24 leet Iong by 30 feet and the callings are 12 leet 6 Inches high. The wells are costed with Plaster of Paris and have been caloimined a 11ght grain coloux. In all cases the largest pietures were preferred on these walls, elther by themselves or when arrenged with other pletures.

These experiments point to the fact that the size of a pioture is a factor influeneing sppreciation, and it is therefore necessary for the teacher of art appreciation to take this factor into consideration in his work in the elassroom. If a pioture is to be suceessfully apprecisted the process must be pleasent and happy and agreeable to a.1, and the prinolple of faclitetion of attention cannot be ignored. The size, setting and freming of each plotrre displayed must always be carefuly considered with a view to the IInel effect as a 
whole. Attention must be naturally focussed where the artiat intended it to be Locussed, and there must be

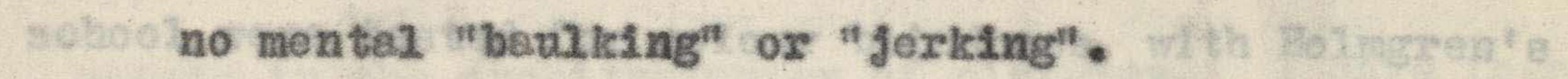

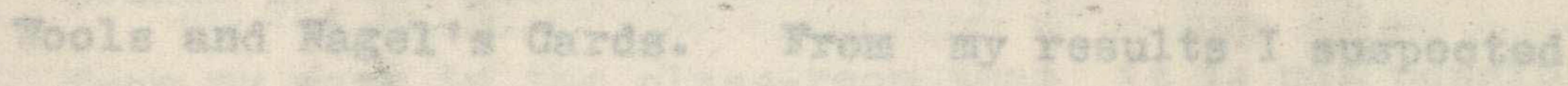

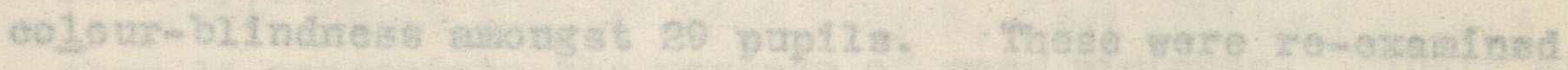

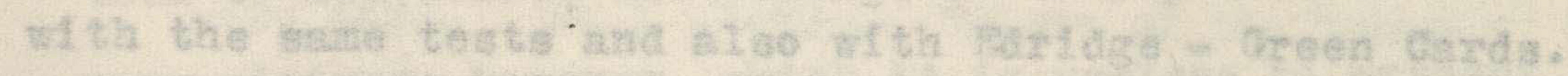

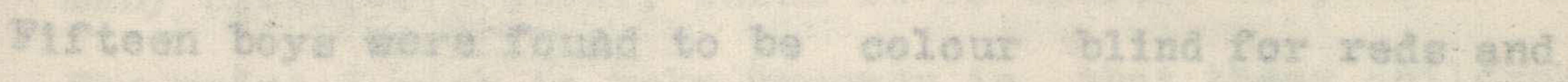
greens, and eleven girl.s wera found to be bilnd for the shme two colours. One bey and two givle were found to be toteily

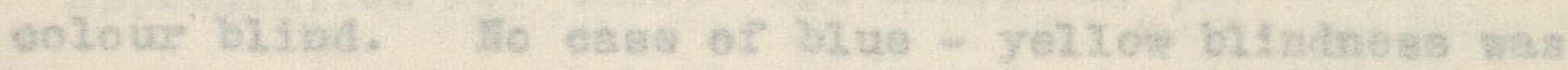
deteeted.

Thess 29 pugils were thon. tested with the eame firree pleturea as ware ased las the expertment desoribed in the Iant

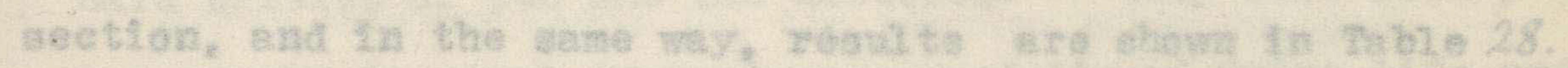
Ti Is rather undafe to drarg any ounclationa from

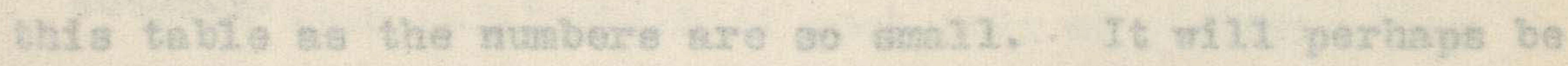
surprieling to note the large number who oliose the caloured pleture in preferones to Plobure No 3. Mins of. these elevera phptla precerred the ploture bscmuss they"liked the $31 x 2$

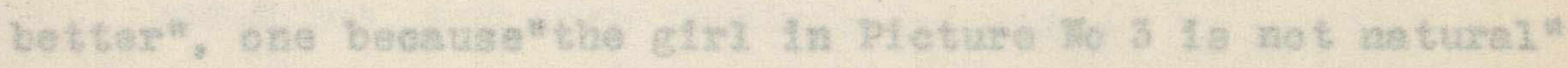

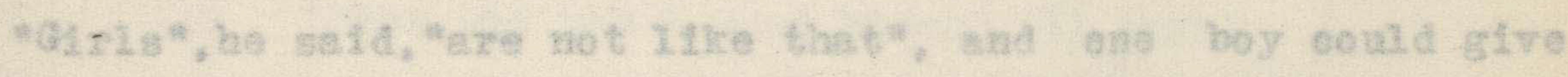
no reason. Seren of these puntis (5 of thenglris) later changed theitr preference to pleture Wo 2, all of them because they preferred the subjeot of the pleture. Fowerer of the I8 puplla whe proforged Ploture No 3 to Meture Mo 1 , only olx remalnod untrue to thelr flrat eholee when Pigture Ho 2 vas shown to then, and this soens to polnt to the faet that 


\section{HEFECTS OF COLOUR BLINDNESS ON APPRECIATION.}

Four hundred and thirty six pupils attending this school were tested for colour blindness with Holmgren's W001s and Nagel's Cards. From my results I suspected colour-blindness amongst 29 pupils. These were re-examined with the same tests and also with Fdridge - Green Cards. Fifteen boys were found to be colour blind for reds and greens, and eleven girls were found to be blind for the same two colours. One boy and two girls were found to be totally colour blind. No case of blue - yellow blindness was detected.

These 29 pupils were then tested with the same three pictures as were used in the experiment described in the last section, and in the same way, results are shown in Table 28.

It is rather unsafe to draw any conclusions from this table as the numbers are so small. It will perhaps be surprising to note the large number who chose the coloured picture in preference to Picture No 3. Nine of these eleven pupils preferred the picture because they"liked the girl better", one because"the girl in Picture No 3 is not natural" "Girls", he said, "are not like that", and one boy could give no reason. Seven of these pupils (5 of themgirls) later changed their preference to picture No 2, all of them because they preferred the subject of the picture. However of the I8 pupils who preferred Picture No 3 to Picture No I, only six remained untrue to their first choice when Pieture No 2 was shown to them, and this seems to point to the fact that 
children with defective colour vision can be taught to appreciate beauty of form and of $11 \mathrm{ght}$ and shade, and of points in the architectonics of pictures. I have found from my work in the class-room that it is not/ possible for them to appreciate the message of many pictures. There are many pictures, however, which it is useless to present to them The point I wish to make, however, is that these children should not be excluded from taking part in lessons in art appreciation for there are many, many pictures which appeal to them and to which they can and do respond.

I might state in passing that these children genuinfy appreciated many etchings whereas they were often very hard critics of pen and ink sketches. They were keenly interested in steel engravings especially of Swiss life and scenery.

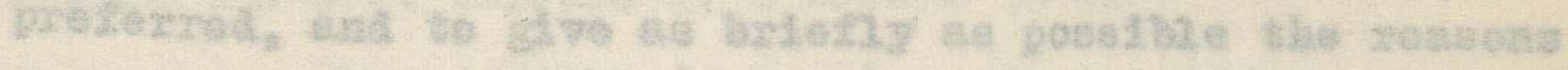

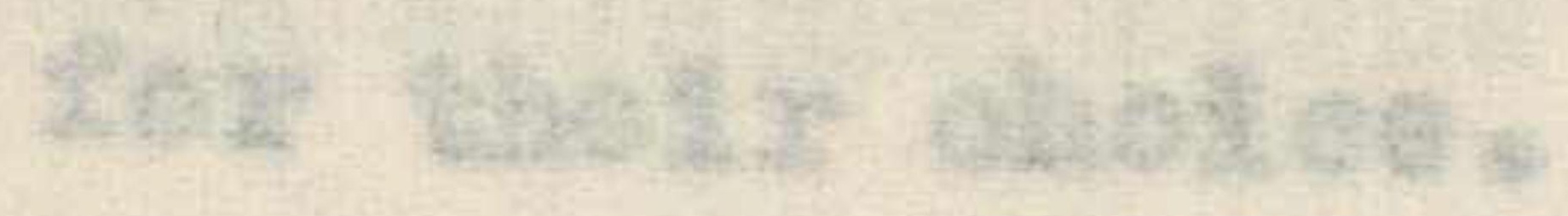




\section{THE BPESCNS OF CONSPANTIY}

SEMTMG PICHURES

During the first week of the first term this year on the walls of the classroom of a form of 35 boys in their first year at High School, four coloured prints were hung. Mo.1 pioture, "Diana of the Uplands" by C.W.Iurse was placed near a highly coloured print of Phar Lap (already mentioned) which I have referred to in Table as pioture No.2. On another wall Turner's "Ra1n, Steam and Speed" (P1oture Mo.3) was hüg near another print, this time of a yachting scene in waitemata Harbour, Auckiand. This (Picture Ho.4) was a really well exeouted print, but had flew $6 f$ the elements of a great pioture about it, the pioture being particularly lacking in balance both of colour and fom. The boys were then asked which of each pair of pictures they preferred, and to give as brienly as possible the reasons for their cholee.

Twenty-nine preferred the ploture of Phar Lap, the racehorse, and gave as their reasons:-

(1) "Phar Lap was a good horse" (11 boys)

(11) "The Lady's hat is out of date" (7 boys) "The Lady's dress is a funny one" (3 boys) "The Lady's hat $100 \mathrm{ks}$ as if it will blow off.(2 boys)

(111) "Phar Lap was a real horse. The other pieture was probab1y made up" ( 2 boys) 
(4) "the scene is too windy", (2 boys).

Two boys were unable to say why they preferred Plcture No 2. and two boys were unable to say that they preferred one pleture more than another.

The reagons of the four boys who chose Plcture

No I were as follows:-

(I) "The colours of Phar Lap are not so natural".

(2) The lady's dress spolls the picture, but it is heal thy".

(3) "The picture is more graceful".

(4) " The greyhounds look as if they are enjoying being taken out. Phar Lap is dead and he is only a horse."

The reasons of those boys who preferred Plcture No 3 to Picture No 4 , were as follows:(I)" I like the soft colours", ( 2 boys).

(2) "The colours blend well". (4 boys).

(3) "The colours are used better". (2 boys).

(4) "I like the ldea of the picture", ( I boy).

(5) "The picture has a $10 t$ in $1 t$ ", (4 boys).

(6) "The other picture makes you feel cold but this one gives you a contented feeling," (I boy).

(7) "I do not know why I like it." (2 boys).

(8) "No reason offered by 3 boys.

No reason was given by two boys who preferred

PIcture No 4 to picture No 3 , butthe reasons, that were given by the other boys were:- 
(I). "The yachts are very graceful, "(3 boys).

(11) "The scene is a healthy one." (4 boys).

(19i)" The tractor looks funny with its big chimney st1 aking up". ( 2 boys).

(iv) "The colours are brighter," ( 2 boys).

These four pictures were left on the walls for the pupils to see, and no comments were made except that two facts wer pointed out:-

(1) "Diana of the Uplands" was the Artist's wife.

(1i) The "tractor"in Turner's picture is a railway engine of the period in which the artist lived (cirke, I I840).

On the last day of the gecond term after an interval of 5 months and I2 days (less a period of two weeks during the Autumnflo11days), the boys were again asked which of each pair of pictures they preferred, and to give brlefly the reasons for their cholce, and Table 29. reveals a remarkable change of opinton.

The reasons of the 25 boys who preferred Pleture No I to Picture No 2 were as follows:-

(I) "the lines of the lady's dress make a triangle," (2 boys).

(2) "The pleture 1 s well set out."(3 boys).

(3)" The lady's hand and dress, and the dogs all point the way the wind is blowing" (I boy).

(4)" There is more in this picture". (3 boys). 
(5) "The ploture makes you feel fresh and heal thy". ( 2 boys).

(6) "The colours go well together", O ( 2 boys).

(7) "Phar Lap's saddle-cloth is too bright" (I boy)

(8) "I am siok of seeing Phar Lap, but I am not sick of the other pleture set."

(9) "I 11ke the dogs and the blue colours", (3 boys)

IO) "This pleture is out of the ordinary" (I) boy.

(II)" The pleture makes me think of when we went out to HImatangi ( a deer-stalking place) in the holldays. "(I boy).

(I2) No reasons able to be given by 5 boys. Six boys were able to give reasons for preferring the picture of Phar Lap, but two gave no reasons The reasons were:-

(I) "The lady's clothes are old fashloned."( 2 boys).

(2) Phar Lap was the champion horse of Australia and New Zealand." ( 2 boys).

(3) "Horses are better animals than greyhounds which are uglyy and treacherous". (I boy).

(4) "The colours appeal to me more." (I boy). The reasons of those boys who preferred Pleture

No 3 to Ploture No 4 are as follows:-

(1)" This pioture has a lot more in 1 t. "(3 boys).

(2)" The longer you look at thls pleture the more you "see in 1t." ( 5 boys).

(3) The train is coming out of the mist in a determined way, but the yaohts are sporting bosts and are not depéndable" (1 boy) 
(4)" The train is coming out of the mist snd it seems mystorlous" (I boy).

(5) "When you go on a railway trip you never know what you w111 see next, and this piature gives you this 1dea". (I boy).

(6) " The yachting pioture is healthy, but the train pleture is more interesting". (I boy).

(7) "Hy Iather has got a picture 11ke this and we al1 11ko $1 t^{\prime \prime}$. (I bog).

(8) "I 11ke real pietures about orainary things". (I boy).

(9) "The rain is beautiful but the sea doesnt look the right colour." (I boy).

fIo)" The colours are well blended". (5 boys).

(II)" The colours of the yachting ploture are too bright and gaudy". (I boy).

only one boy gave no reason for his preferenoe. On the other hand the reasons of those boys who preferred Pleture No 4 to Ploture No 3 are:(1) " The picture of the yeohts has got more 1ife in 1t"( 2 boys).

(2) "The train pleture secms sad". (I boy).

(3) "The train is out of date".(2 boys).

(4) "The train ploture is too misty" (I boy).

(5) " The colours are bright".$(3$ boys $)$.

(6) " The sun 1s shining on this pieture and is making the sea glitter". (I boy).

The changes in the attitudes of the boys 
Boys examined towards these pietures clearly indicate that faniliarity with good pictures is essential for proper aesthetic appreciation. It is romarkable that the " old Iashioned hat and dress" are not once reLerred to in the second examination, and the " out-oldate tra in" is only once mentioned in the same test, despite the faot that this type of reason was at 21rst given for choosing another pioture by no less than one third of the cless. It seoms that the underlying psychological prinoiple here indicated is that referred to before, that of facilitation of attention, and this principal must never be overlooked by the teacher of approcietion of piotures. Most children are able to appreciate certain pictures even though the conception and exeoution of those pietures be of a complex nature, provided that time is allowed for those chlldren to percelve the unity that exists in the midst of the complexity.

IIy own observations as woll as the evidence of this experiment indicete that the coneeption of even many simple plotures is beyond the Immediate grasp of these children, for their attention is at Iirst attracted by aingle foatures - not always of novel ty but sometimes of colour or form. This interferes with the immediate apprehension of the wholes. By constently goofing these pietures hoever, Ianlliarity is gained with these points, and the attention is thus freed and alreoted 
to the pioture as a unit.

This experiment inaicates also the necesalty for the teaching of appreciation in the olassrooms. Although the reasons given do not show that merely seeing plotures constantly, helps ohildren to apprealate "good" pletures and helps them to prefer these to pletures of less worth, nevertheless these very ressons st111 demonstrete a low degree of aesthetic development at lesst in this department of Art. The necessity for guidance in appreciation is oleariy manifest.

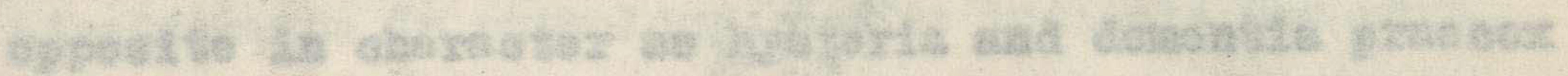

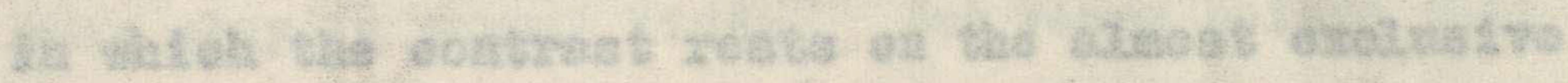

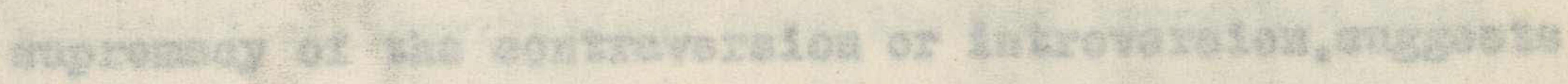

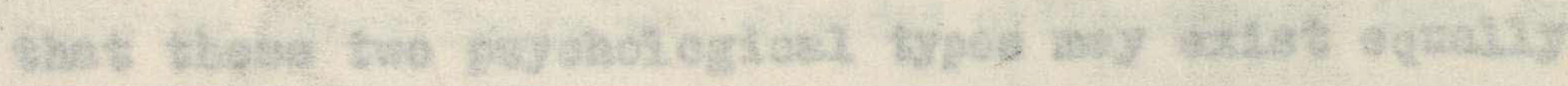

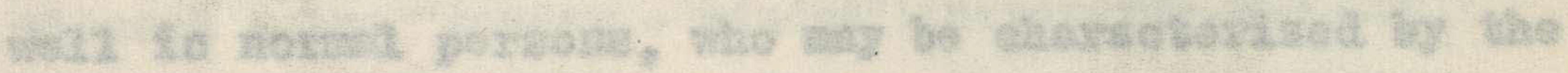

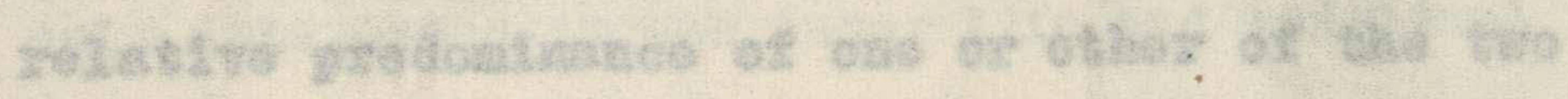

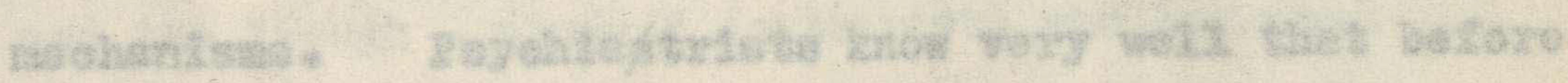

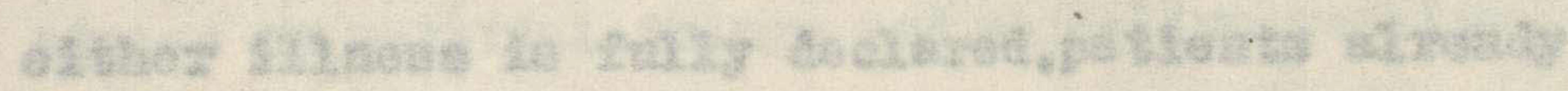

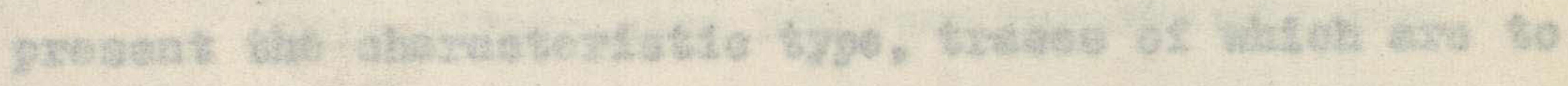

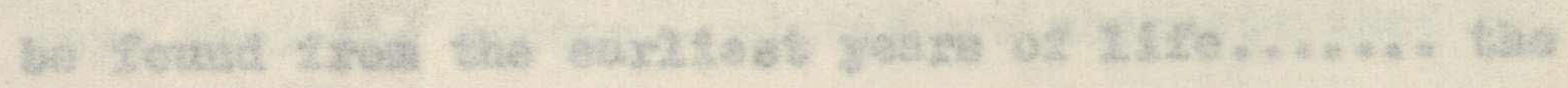

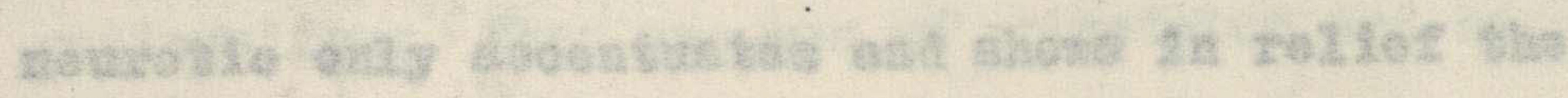

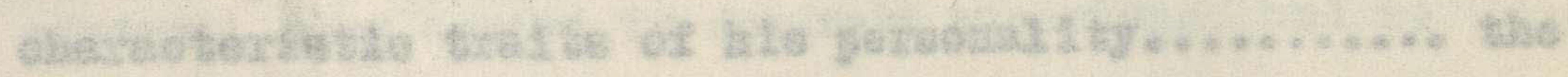

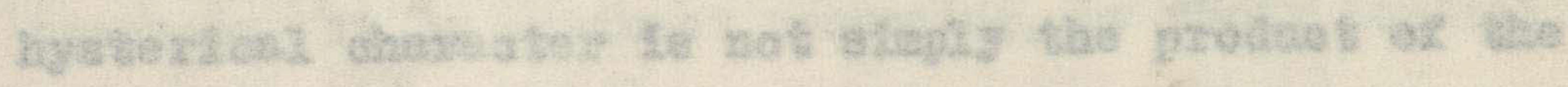

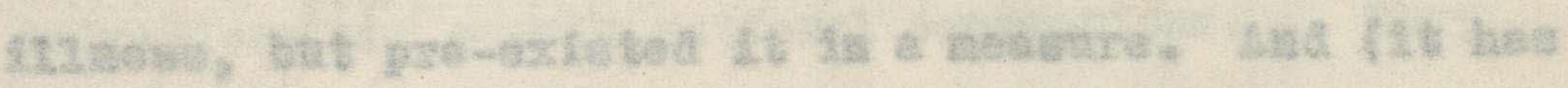

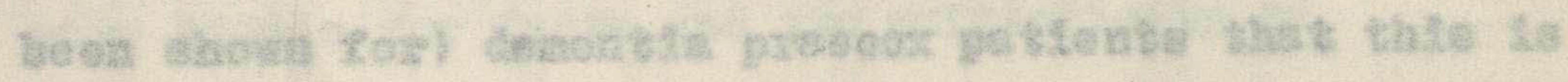

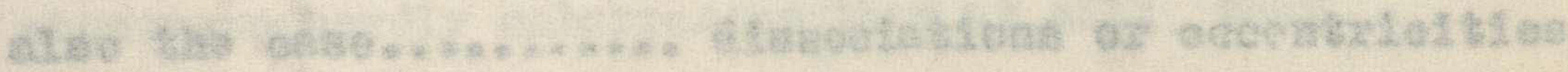




\section{THE EXYRAVERT AUD TWTROTERP TYPES}

Some years ago the discovery was made by Jung thet among ouxselves there are two fundamenta11y opposed. pagohologieal "types" or dispositions, the extrevert and the introvert. Jung reached this concoption by a consideration of the striking contrast in thelr reactions to the external world,presented respectively by sufferers from two disoases, hysteris and dementia praecox. In his book "Analytieal Paychology" (I9I7),pages 289 and 290, he says: "The existence of two mental axfections so opposite in character as hysteris and dementia precox In which the contrast rests on the almost exclusive supremacy of the contraversion or introveraion, suggests that these two paychological types mey exist equal1y well in normal porsons, who may be characterized by the relative predominance of one or other of the two mechenisms. Isychiaftrists know very well that before elther 112 ness is fully declared, patients already present the chareeteristic type, traceg of which are to be found from the earliest years of $11 f e . . . . .$. the neurotic only egeentuates and showe in reliel the eharacteristio treits of his pexsonality .......... the hysterleal charecter is not simply the product of the 111ness, but pre-existed it in a messure. And (1t has been shown Lor) dementia praecox patients that this is also the case......... dissocistions or eccentricities 
were present before the onset of the 111ness. If this is so, one may bertainly expect to meet the same contrast between psyohological temperements outalde the sphere of pathology. It Is, moreover, easy to cull from $11^{\text {torature }}$ nume rous examples which bear witness to the eotwal existence of these two opposite types of montal1 ty."

It may perhaps be quite right to designate Jung as the discoverer of the two types, since he was the Iirst to systemizetheir aifferences, to show their significence in pathology, and to indicete the part they play in normel 11fe. But yeers before this the soundest of observations upon the two types had been made by Henry James, who divided philosophers into two classes - the "tender - ininded"(Introvert), who are only interested in the inner life and spiritual things, and the "tough - minded", (extravert), who lay most stress on material things and objective reality. Opere o1 ta to,page 290 , Jung remarks: "James says that the tender - minded are characterized by rationalism; they are men of prineiples and of systems, they espire to dominate experience and to transcend it by abstreet reasoning, by theix $10 \mathrm{gleal}$ dedvotions and purely rational conceptions. They care 11ttle for facts, and the multiplielty of phenomene hardly emberrasses them at all; they forelbly fit data into their ideal constructions, and 
and reduce everything to their a'priori premises. This was the method of Hegel in settling beforehand the number of the planets. In the domain of mental pathology we again meet this kind of philosopher in paranoies. who, without being disquieted by the flat contradiotions presented by experience, Impose thelx delirious conceptions on the universe, and find means of interpreting everything, and, according to Adler, 'arranging' everything, in conformity with their morbidy preconceived system"

The other traits which James deplets in this type follow naturally from its fundamental oharacter. The $11 \mathrm{bido}$ is concentratod almost exclusively upon the intellectual 11fe, and this concentration upon the inner world of thought is nothing else than introvergion.

Continuing on page 291 Jung says: "whe tough-minded man is positivist and empinioist. He regards only matters of fact. Experience is his mater, his exclusive guide and inspiration. It is only empirical phenomena demonstrable In the outside world which count. Thought is merely a reaction to external experience. In the eyes of these philosophers prinoiples are never of such value as facts they can only reflect and describe the sequence of phenomina. and cannot construct a system. Thus their theories are exposed to contradiotion under the overwhelming accumulation of empirioal material. Psychic reality............ 1 imits 
itself to the observation and experience of pleasure and pain; he (the positivist) does not go beyond that, nor does he recognise the rights of philosophioal thought."

But in spite of the reality of the two types and the ease with which their extreme examples are recognised, it must be admitted that it is not easy in any general formula to express their eontrasting reactions to the obje ot. Even Jung fully recognises this (of."Psychological Types" pp $12-14$ ). Horeover, he points out that this grouping must be extended, or rather that within each group eategories arise acoording to "the predominance of one basic funotion in the individual." As besic funetions there exist "thinking, feeling, sensation and intuition. If one of these functions habitually prevails a corresponding type results. I therefore discriminate thinking, feeling, sensation and Intultive types. Everyone of these types can, moreover, be introverted or extraverted according to his relation to the object in the way deseribed above." In his earlier communications concerning psychological types, Jung did not distinguish the feur types outlined above, but identified the thinking type with the introvert type and the feeling type with the extravert. In the main I have accepted this division in this thesis.

The existence of the two "types" being admitted, and it seems to me that as to this there can be no doubt (though naturally most of ns are not extremes of either type, to be elassified at sight) it becomes not only interesting, 
but from the teachei"s point of view, imperative that these types be sought for in the classroon.

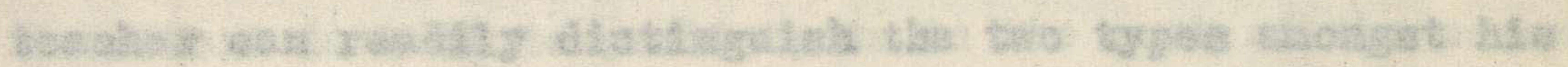

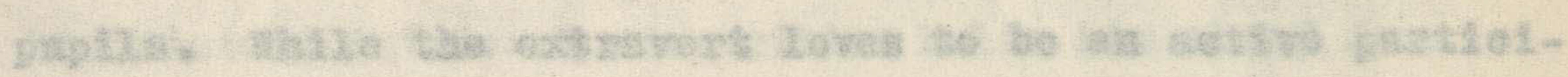

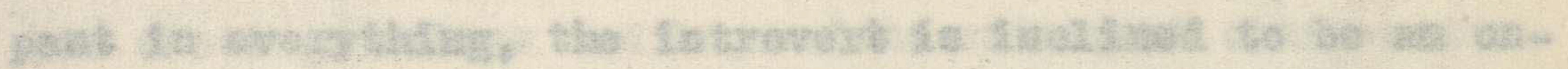

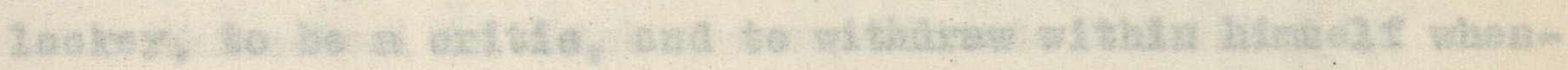

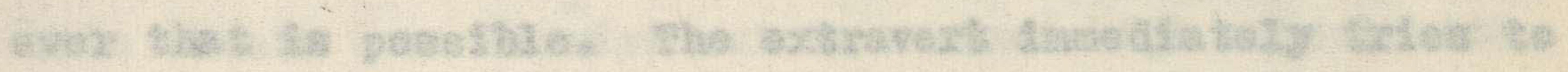

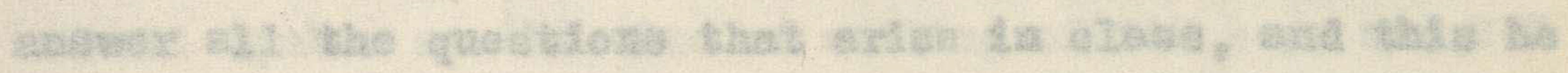

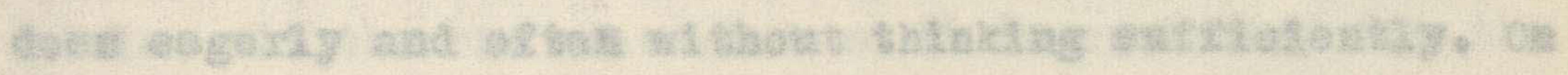

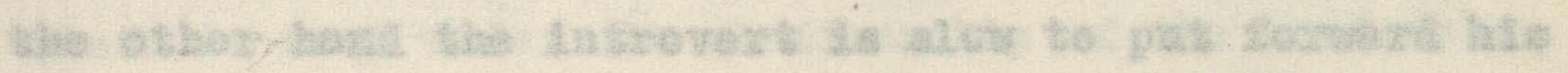

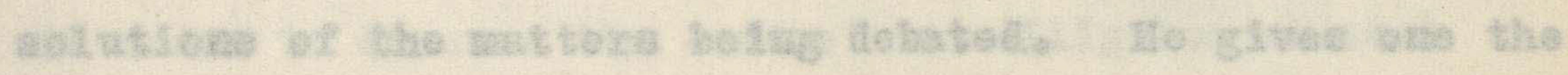

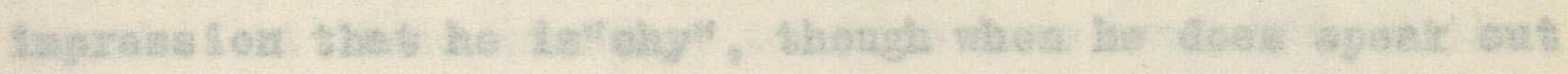

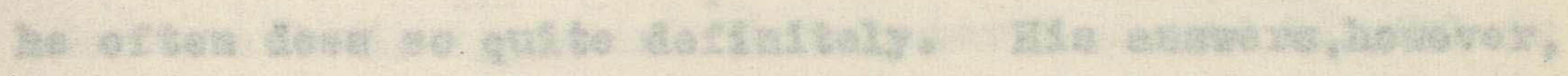

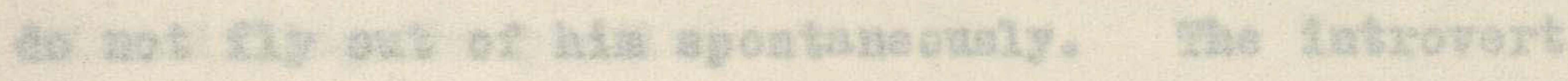

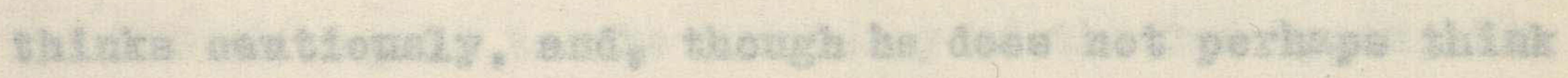

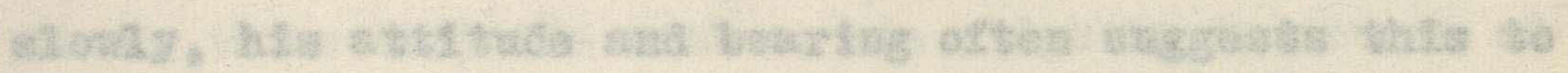

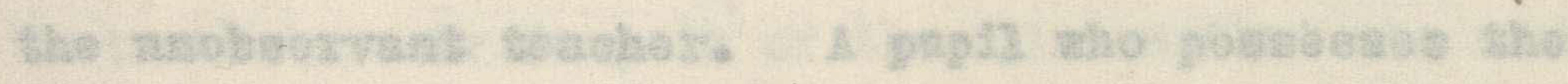

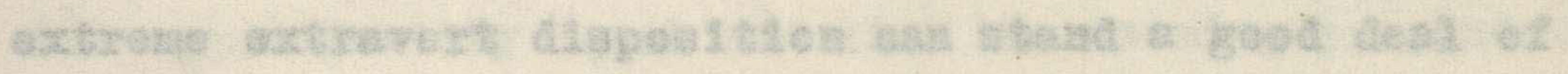

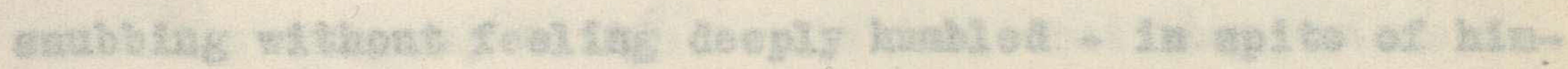

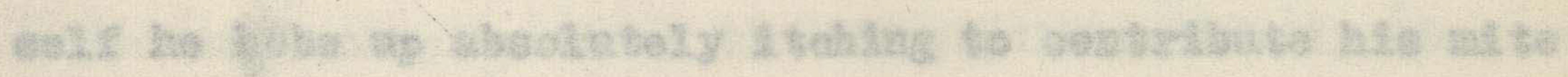

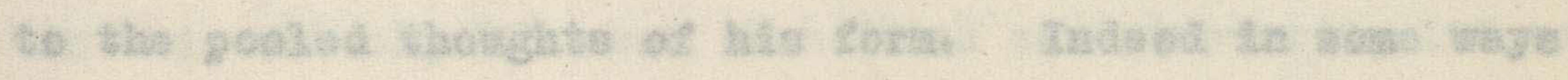

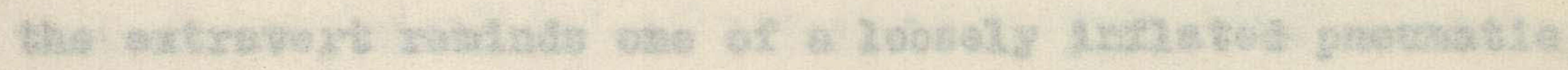

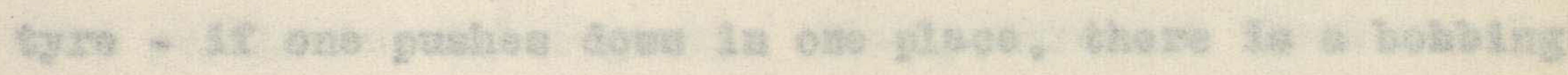

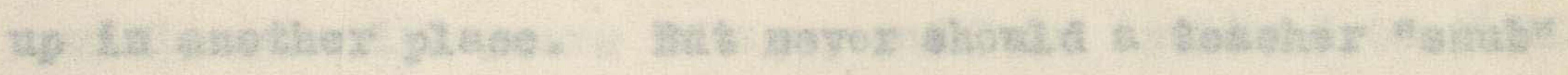

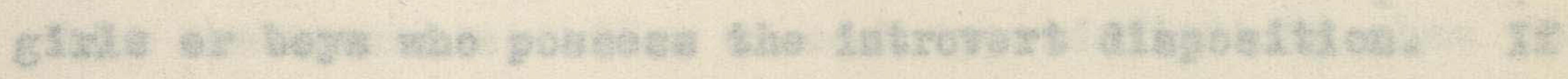

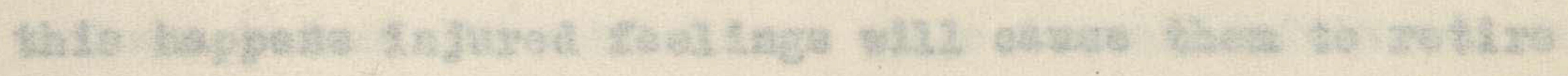




\section{THE TYPS IN SCHOOL}

In the olassroom and in the playing fields the observant teacher ean readily distinguish the two types amongst $\mathrm{his}$ pup11s. While the extravert loves to be an active participant in everything, the introvert is inclined to be an onlooker, to be a oritie, and to withdraw within himself whenever that is possible. The extravert immediately tries to answer all the questions that arise in class, and this he does eagerly and often without thinking sufficiently. on the other hand the introvert is slow to put forward his solutions of the matters being debated. He gives one the impression that he is"shy", though when he does speak out he often does so quite definitely. His answers, however, do not IIy out of him spontaneously. The introvert thinks eautiousiy, and, though he does not perhaps think slowly, his attitude and bearing often suggests this to the unobservant teacher. A pupil who possesses the extreme extravert disposition can stand a good deal of snubbing without feeling deeply humbled - in spite of himeelf he bobs up absolutely itching to contribute his mite to the pooled thoughts of his form. Indeed in some ways the extravert reminds one of a loosely inflated pneumatic tyre - if one pushes down in one place, there is a bobbing up in another place. But never shovld a teacher "snub" girls or boys who possess the introvert disposition. If this happens injured feelings will eause them to retire 
within themselves. In extreme cases dark and brooding looks mantle their faces, and a distant silence will be maintained for some considerable time. Even though the introvert is keen to partieipate in the work of the moment his dIstant introvert aisposition holds him aloof from his often querolous and loquacious extravert alass-nates. The sohool in which the experiments described in this thesis were carried out is a mixed high schonl with a roll number at the time of writing of 249 boys and 207 girls. At the end of each term it is customary for the staff to meet under the chalmanship of the headmaster In order to discuss the oonduct and diligenoe of each papil. At these meetings teachers have remarked on the oharacteristic types and their remarks proved helpful in elassifying the pup11s.

with regard to the frequenoy of the two types, It seeme to me that the numbers are slightly in favour of the extraverts. Dr.Jung is of the opinion that the numbers are approximately equal and that the seeming preponderance of extraverts may be due to the fact that they are as a rule more conspicuous of the 450 pupils carefully observed in this school, 121 were elassifted as extraverts, 103 as introverts, while $1 t$ was difficult to place the remaining 226 pupils in either group. Winety-three of these remaining pupils were 12- years of age, and I am inclined to think that the characteristios of each type definitely show themselves before the adolescent stage is well advanced. During 
my seven years' teaching experience I have noticed that pupils (partiovlarly boys) may in the third form appear to be developing definitely as extraverts, yet by the time that they have reached the upper fifth forms, be judged as introverts.

of the 121 pupils olassified as extraverts, 65 were girls and 56 were boys, and of the 103 introverts, 52 were girls and 51 were boys. These figures seera to indicate that the psychologioal types are approzimately equally distributed between the two sexes.

No attempt wes made to distinguish between Dr Jung's "attitude" types and "function" types. It seems that an investigation as to the preferences, reactions etc, of Jaensch's Besedowoid and Tetanoid types (based on the types of "eidetic" images experienced) might be useful to the the teacher of art appreciation. The present writer tentatively made a classification on these lines, but he was so far from satisfied with the accuracy of his first classificat ion that he abandoned further enquiries in this direction. The assistanue and advice of an expert psycologist is required before such a distinction can be safely made. The order of the colours preferred by the children classified as extraverts or introverts was as follows:- 
TXTRAVRRTS

\begin{tabular}{llll}
\multicolumn{1}{c}{ Bovs } & Girls & Bovs & Girls \\
\cline { 2 - 4 } Blue & Bue & Green & Blue \\
Green & green & Blue & Green \\
Yellow & Red & Violet & Yellow \\
Red & Violet & Yellow & Thite \\
Violet & Yellow & Red & Red \\
Thite & Thite & White & Violet \\
Black & Black & Black & Black \\
\hline
\end{tabular}

\section{INTROVERTS}

\section{Boys}

Bate
The reasons given by each pupil were carefully scrutinised and often verified by personal enquiries, and were classified as follows:-

Type of Reason

Fixtraverts

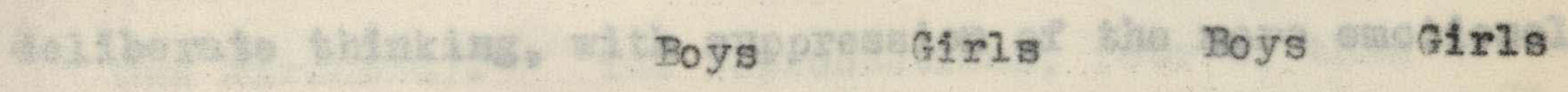

\begin{tabular}{lllll}
\hline I. Objective & I5 & I4 & 7 & I2
\end{tabular}

I. Objective

2. Physiological

3. Associative

4.

Number of Pupils
I4.

29

26

5

56

8

65
IO

6

8

(n)

$+$ \\ Introverts \\ 6 \\ 8 \\ 3 I \\ 25 \\ .}




\section{THE TYPES IN RIOTORIAL AFI}

In a number of artioles in the Burlington Hagazine (May 1920, July and sagust 1921) Mr.Alfred Whornton with Dr.Ronald Gordon polnted out (I believe for the IIrat tirge) that as far as Europe is coneerned, the works of famous palnters fall into two claases distinguishable at sight in the more pronounced ixistanceg, and thet these clesses each exhibit a characteristic facies corresponding to one of the two psychologioal types. Browdy speaking it is held that that form of painting usually termed "glaesioal" is charaoteristie of introversion, while "Romantie" painting is of the extrevert disposition.

A picture by an introvert painter is characterised by deliberate thinking, with suppression of the more emotional. types of symbolism, and always severity of form is emphasized. The introvert peinter's work is thorefore carefully drawn, somewhat hard, severe in outilne and inclined to be arid in colour, at best the colour schemes are restrained and relate very exactly to the design of the pleture, but with 11 ttle verve.

on the other hand, when a painter is of the extravert type his colour is full and rich, often lusolous, the form Is not exset; but the lines are free and Ilowing and tend to exaggeration of novement, their dynamic quality being In string contrast with the static tendenoy exhibited by 
the introvert's careful compositions. Intravert work, even if slowly produced, still gives the impression in many cases, of having been executed in a white heat of passion, and the brushwork is vigorous, at times to the verge of brutality, differing vastly from the thin, dry tech nique of much introvert painting. So it may be sald that the general character of the type of work produced by the extravert betfokens emotional emphasis. and is accompanied by apparent carelessness as to detain and absence of severity in form.

For purposes of this thesis the writer, after a study of the lives and works of painters, selected "pairs" of painters working respectively in the 16th 17th centuries (Rubens and Poussin), the 18th Century (Delacro1x and David) and at the present day (signac and Marchend). The reproductions, four of them Nedicl prints, that were used, are as follows:Mxtravert: Rubens. "Danza Compestre", Delacroix, "Dante et Virgile"; Signac, "The Harbour of La Rochelle: Introvert: Nicholas Poussin, "Bacchanal"; Jacques Louis David, "Oath of the Horatil"; Marchand, "The Harbour of La Rochelle". Rubens $(1577$ - 1640), who has been taken as typica] 
extravert, was characterised by rapidity of ereation and great powera of making use of every imaginable subject. As a man he was a bon vivant and lover of soelety and his style that of an eloquent narrator amused by his own talking. not much affected by difficulties, or really troubled to any profound extent or harassing himself with subtle research. He preferred 1useious forms and rich colours, clarity and strength to depth and distinoti on. Sensual in temperament, his canvases show this, and they are not ennobled by high aspirations or implielt tendenoy. IIs nudes are brilliantly expressed and elear in form, but nothing in them brooded or dreamt about. The rollicking sensuality and joy of the "Danza Compestre" tells its tale clearly enough and proclaims the artist to be a lover of heal th and healthy himself, a thorough extravert going jogoasly out in to 11 ife.

Hicholas Poussin of the period $(1594$ - 1665) was a true introvert. His painting wheta contrasted with the work of Rubens at once procla ims itself the result of an emphasis on thought rather then emotion, on abstract 1 dees rather than on rapidy summarized actuality. His pictures are vigorous in coneeption and correctly drawn, but his nudes heve nothing vibrant in their Ilesh. De the many Bacchanals painted by him none ever seem to smile or show traces of real voluptuousness. His colour is too considered, though he finally attained a noble type of harmony that bewame satisfying through its complete accord with the nature of 
his designs rather than by any intringie emotional element. Perhaps his landscapes are the most successful of his works from this partiouler stendpoint, thanks to a dasareet tonality. His attitude to life was thoroughly intwovert and in marked contrast in its considered caution to Ruben's gay abandon. From his lettexs it appears that his ideal was to be intellectually Iree, always master of himself, allowing no fury of ereation, and to treat nature as a language whereby the various human emotions covld be expressed and communicated to the world, These and other objects were attained by the most arreful and laborious research. He even studied the nost minute details of contemporary archaeological discovery for his pictures, leaving nothing to chance. His work was always deliberate (inentire contrast to Rubens, whose dozens of rap1 d1y executed canvases revell an enornous power of covering space, even after due allowance be made for collaboration) Mon naturel me constraint de ohercher les choses bien ordonndes", says Poussin. His "Ba.cchanal" shows these charaters in almost diagrammatic form as contrasted with Rubens' Plorid design in the "Danza Compestre Delacroix (1799 - 1863) Is regarded as leader of the Romantic Sohool which, culminating in 1830, had arisen as a protest against the tyranny of Greece and Rome exereised over the French peinters just preceding him. His admiration for Veronese and Rubens was unbounded, and he took his subjects from Dante, Shakespearen Byron, eto. His drawing 
was characteristic of his type, belng inexect, yet expreseing the life and spirit of his motif with often feverish energz. The work exhibits bold techniquo and a full flow of paint as woll as richness of oolowr. The scmber splendour of coleur in the "Dante et virgile" is equalled by the violent gesturea of the figures. A typloal extravert, he was anathena to Jaeques Louls Devid $(1748$ - 1825) who, standing in complete contrest to him, has left a wonderful series of paintings unequallod In art for delloaoy and exnotness as woll os subtlety and verve. The teatile values are as keenly felt as by any plorentine axtist.

But like his prototype, Poussin, Devia was incapable of expressing pession snd emotion, as is well shown by his "Oath of the Horeti1" . HIs colour sense - the emotional element - was defective sineo hls work is at once violent jet ân11 in colour. His feeling against the charecteristios of extraversion in painting ran to bittex lengths, even to personal abuse. An introvert, he rather shunned soclety, whereas Delacroix sought it out, al though his selection was carefully made.

The writer was Iortunate enough to obtain (though not Hediel printe) reproductions of the works of two modern Frenchmen, Paul signae (extrevert) and Jean liarchand (Introvert). They were representations of the same scene - the harbour of Le Roohelle - and their alfforance in approach

to the same subjeot is most striking. Both artists are serious 
men and highly esteemed in Franoe and Great Britain, not merely on the ground of present work but also of past achievement.

To sum up: considering first the work of Rubens, Delacrolx and signac, we see in all three painters a freedom of $l i n e$ and $v i$ tality of expression in form carried out at the expense of exactness. This type of artist emphasizes the emotional element in painting, and the colour harmonies chosen by these men correspond exactly to their mental temdencies. On the other hand, a short consi deration of the work of Poussin, David, and Marchend, betreys a definite emphasis on the intellectual tather than emotional side of art. The whole of their compositions are definitely planned and nothing left to chance or happy Ineident whioh ray oome into being in the course of painting in the impetus manner of introvert painters such as Rubens and Delacrolx. 
The reactions of chilaren of the two types to pictures by extravert and introvert artists.

The first consideration in this problem was that of the method of investigation. The following were considered perhaps more carefully than others:1. The Method of Impression as used by Fechner.

2. The Methods of Minimal Charges, Average Frror and Right and Wrong cases (also used by Fechner).

3. MoDougall's Method of Serial Groups.

4. Cohn's Method of Paired Comparisons.

5. The Method of Mrpression devised by Lehmann.

6. Calkin's Method of Paired Associates.

7. Galton's Questionnaire Method

8. Cattell's Order of Merit Method

9. Coreelation Methods

10. Methods of Introspection.

11. Kulpe's Method of Fractionization.

12. The Aneciotal Method used by Romanes.

13. Yerke's Multiple Choice Method.

The final choice of the method used was made only after several trials had proved the suitability or otherwise of the method for the problem in hand. A few methods were obviously inappropriate and others which seemed at first both efficacious and relatively easy to apply were found to be after all only apparently so. 
For instance, I have found as a result of my experiments that the re thod of investigating the feelings of children by the method of introspection is by itself unreliable. This is perhaps not very surprising.

Psychologists give many different defintitions of the nature of feeling, and these defindtions all seem to be in agreement with Tundt's statement that feeling is given us in experience as a subiective reaction of consciousness on an outward impression" - in other words, psychologists agree that the feelings are processes of consciousness that lie nearest to the self. It is therefore specially difficult to investigate the feelings of children.

(1) Because young children find it difficult not to identify themselves with their feelings, even in the later adolescent stage of their development, for the simple reason that these feelings stand in the closest relation to the observing self.

(2) Because feeling is a very changeable process. Sensations are comparatively constant phenomena, but experiments made in the classroom show that even the sensations experienced by children change, just as they do with adults. I gave each pupil of a mixed class of girls and boys a large sheet of green paper, and ealeh pupil made written comments on his or her sensations. 


\section{8}

A11 remarked a chenge from the first moment of daservation. This was also the case when the colour was observed with only one eye, and then from time to time by opening the other eye in order to compare the change going on. In all cases the pupils noted a loss in saturation for the eye upon which the colour stimulus was working continuously. This was only a difference in intensity. The feelings of children are even more changeable.

(3) Because methods similar to that just described can only be indirectly used in experimenting on the feelings and emotions, and one cannot be certain that the expected emotion has arisen, or that an emotion has arisen as a result of the controlling factors of the experiments

Nor is the method of Investigat ng the feelings and emotions of children by observing bodily changes much more reliable. If a child is affected by a picture or has grasped 1 ts meaning one might reasonably suppose that there would be a difference in the heart beat, a difference in the rhythm of breathing, and a change in flow of the secretions of certal $\mathbf{n}$ glands. One might also expect that by determining these guantitively, definite conclusions could be arrived at.

Mxpectations that results would be easily obtal ned in this way were held by the writer of this thesis 
before he actually made experfments. It Tes sf sowse impossible for him to measure any changes in the flow of secretion of glands, but he did attempt to vesure differences of $\mathrm{kr}$ eathing and of the beat of the pulse, when pictures were presented to certain children.

The aim of the first experiments made vas to obtain a series of normal curves by re ans of a kymograph, cardiograph and pneunograph. The experiments at first seemed quite successful for after. I had tested thirty-four boys I obtained curves which seemed to indicate that a feeling of pl aasure kes the he art beat slover and stronger than usual. I then obtained curves of $\mathrm{kr}$ eathing and pulse for 25 extravert and 25 introvert boys, but the curves were so diverse that it was impossible to draw any general inference from them. I did obtain a series of 12 curves from different boys which were very rearly coincident, and which definit ely pointed to the conclusion that the extraverts were affected by (one hesitates to say appreciated) pictures by extraverts more than by pictures by introverts. This conclusion is, however, not a valid one, for apart from the fact that the numbers were too few to justify the "inductive leap". I found on questionIng the boys afterwards that they did not all feel about the pictures in the same way nor to the same extent despite the fact that their curves rore similar. Too many of the boys also told me that they were thinking more of the experiment than of the pictures. My appara- 
tus was not to be trusted either. As the school in which the experine nts were made is some miles distant from my college, it was necessary to use a "home-made" kymograph which was difflcult to handle. It was made from an old selsmometer and a clock, and had to be constantly wound up, otherwise the eelocity of the turning of the drum slowed down, and thus rendered useless the curves obtained. The tambour for recording the beat of the pulse was rather tightly adjusted at first but worked loose after a little use, and had to be retightened. The cardiograph and the pneumograph were obtained from a retired doctor of ne dicine. They were huge contraptions made of thick rubber, and apart from the fact that it was difficult to forget about them when they were adjusted, they were not very sensitive to changes in pressure.

Despite the poor results obtained I am inclined to believe from these experiments that this mo tho of investigating the amount of appreciation of pictures by children, or even by adults, can only be approximate, and that a statement by the child or adult will always be needed.

When the pietures were presented to the children Individually or in the classroom I carefully noted. facial changes of expression and bodily movements such as movements of the hands, and I fo und that wese changes were often surprisingly uniform. In general. 
these changes were more definitely noticed among the older boys than among the giris. It was comparatively easier to judge from these signs whether the older extravert boys appreciated a picture than it was to judge whether the introverts appreciated that picture, and in general it was easier to judge the amount of appreciation by younger pupils than by older pupils.

Although the simple method of investigation of showing a child a picture and then asking him or her to make some statement about it, is not always reliable, it was nevertheless the method here used to discover the reactions and attitudes of children of the two psychological types to the pictures already indicated. These statements I have not recorded partiy beceuse time did not re rmit me to note them all down, and partly because doing so would have interfered with the efficacy of the experiment, for I noticed that as soon as I began to take notes the children's attention was distracted from the picture presented to them, and continuity of exporience became broken. I did, however, note down the types of 1235 remarks made. Classified on the same lines as the reasons for the preferences of colours, the percentages of each type of remark are:-

\section{BY BXIRAVERTS :}

(a) Concerning pictures A.B. and Subjective $11 \%$ objective $45 \%$

Associative $38 \%$

Character type $6 \%$ 
(b) Concerning Pictures B.F.and G.

Subjective: $14 \%$

objective : $51 \%$

Associative: $29 \%$

Character type: $6 \%$

2. BY TNTROVRRTS

(a) Concerning Plctures A.B.and C. Subjective: $\quad 12 \%$

objective : $\quad 42 \%$

Associative : $35 \%$

Character type : $11 \%$

(b) Concerning Pictures B. F. and G.

Subjective : $7 \%$

objective : $48 \%$

Associative : $31 \%$

Character type : $14 \%$

While 11stening to these remarks being made as the children looked at the pictures. I was impressed by the fact that as soon as the statement began to be made the feeling element began to disappear, and that empathy also became far more difficult. Speaking seemed to swey the course of associations. The longer the statement the more this became noticeable. At first reference to feelings was often made, but when the children tried to explain the objects in the picture, and to give their thoughts and judgments as to content, and then future references to feelings becare fewer and more vague. Interfections and exclamations were sometimes particularly significant and often at once indicated the attitude of the child to the picture.

Table 31 summarizes the results of many months of work. The value of this table depends largely upon the accuracy of the classification of the girls and boys into the two types. I believe, however, that 
thet this classiflcation was as nearly perfect as it was possible to make 1 t. Now that the investigation is finished I believe better results would have been obtained had I reduced the numbers by one half, and worked only with those girls and boys who were more nearly pure types. I belleve that then the characteristic preferences of extravert children in contrast to those of children of the opposite type would have been more clearly defined. As it is, one feels doubtful about the validity of conclusions being arpm from this table, al though the results do happen to be approximately in line with impressions gained during sereral years of teaching. The table is clear enough, but in conclusion, I wish to point out that :- 
1. On the whole pictures by extravert painterg were preferred more by girls and boys than were pictures by introverts ( 942 preferences as against 778 preferences Thisbears out personal observations for I have, for instance, noticed that Holbein's portraits have been more popular with children than have Titian's.

2. On the whole, pletures by extravert painters appealed more to extravert children than did pictures by artists of the introvert disposition.

3. In the aggregate these two statements are not Inapplicable to children of each sex-group considered separately, but the preferences of the girls were more definite than were those of the boys. 4. The order of preferences by the extravert children were:-

$$
\begin{aligned}
& \text { Picture A. - } 205 \text { - Pirst } \\
& \text { Picture B. - } 158 \text { - Second } \\
& \text { Picture C. - } 144 \text { - Third } \\
& \left\{\begin{array}{l}
\text { Picture F. - } 128-\text { Fourth } \\
\text { Picture G - } 127-\text { Fourth }
\end{array}\right\} \\
& \text { Picture B - } 110 \text { - Sixth }
\end{aligned}
$$

5. On the other hand the order of preferences by the introvert dhllaren were:-

$$
\begin{aligned}
& \text { Picture B. - } 171-\text { First } \\
& \text { Picture A. }-151-\text { Second } \\
& \text { Picture B. - } 148-\text { Third } \\
& \left\{\begin{array}{l}
\text { Picture G. }-136-135-\text { Fourth } \\
\text { Picture G } \text { G }
\end{array}\right\}
\end{aligned}
$$


Pieture 3. - 107 - Sixth

6. The order of preferences of the children taken in a body were as follows:-

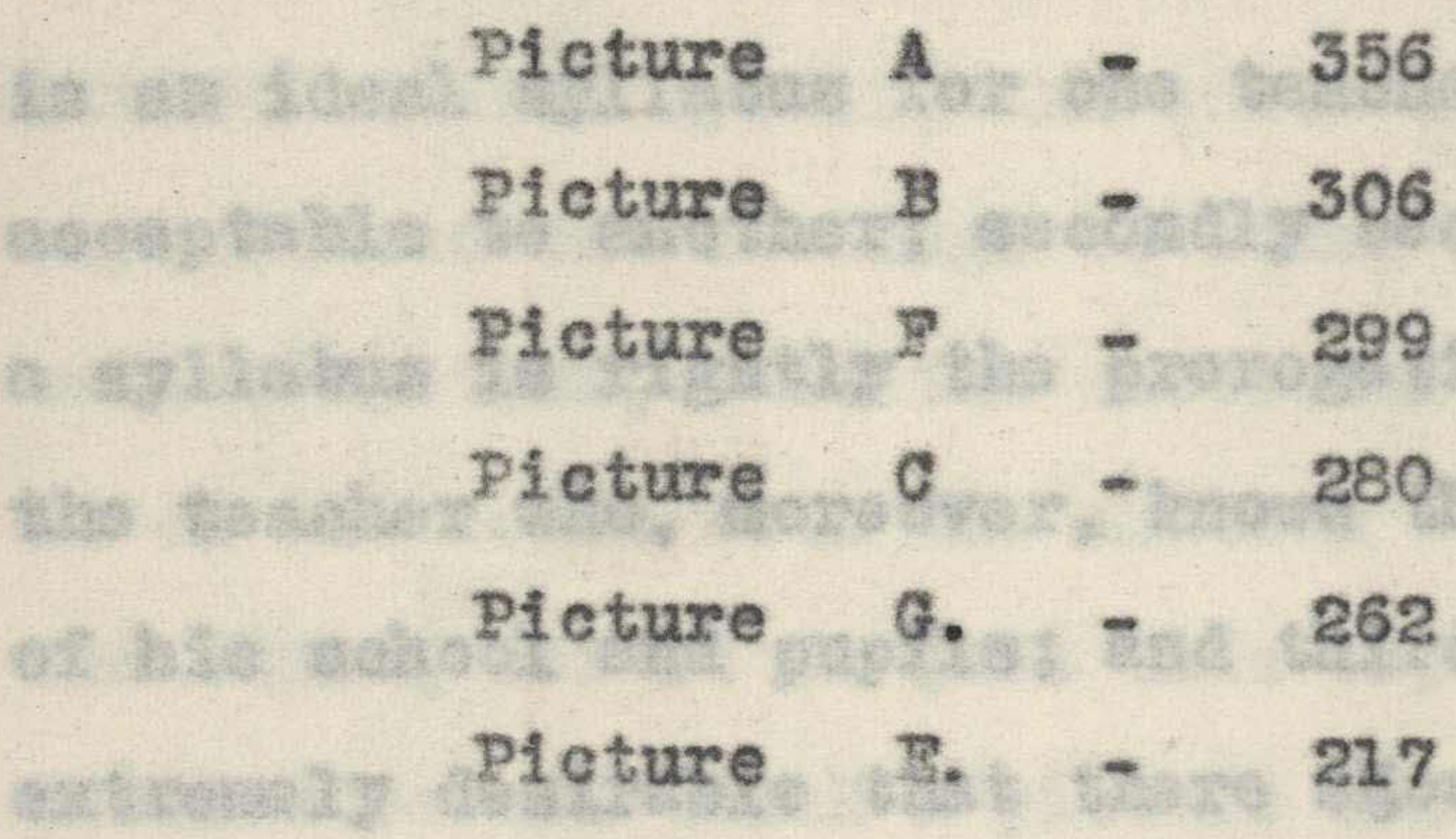

7. The order of preferences of th girls and boys Tere:separately

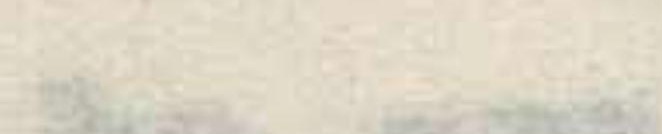

$$
\text { Boys }
$$

Picture A $\quad 179$ Girls

\section{cand}

pleture

156

Picture B 156 )

$\left.\begin{array}{ll}\text { Picture B } & 150 \\ \text { Picture B } & 143 \\ \text { Pleture C } & 143\end{array}\right\}$

picture C. 137

Picture G

132

Picture $\mathrm{B} \quad 109$

Picture 72108

The "key" to these summarles is given in Table 30 .

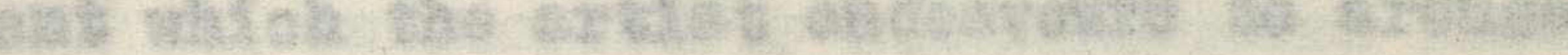

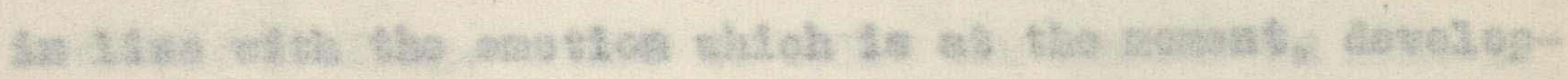

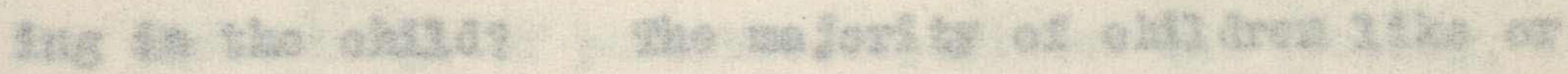

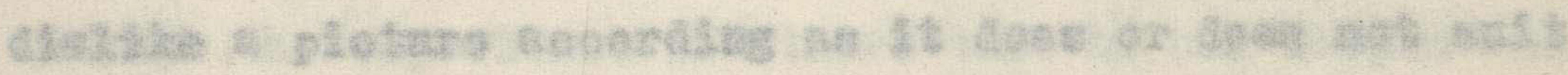

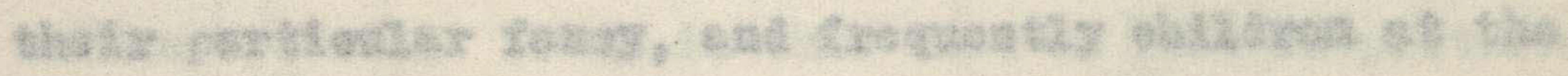

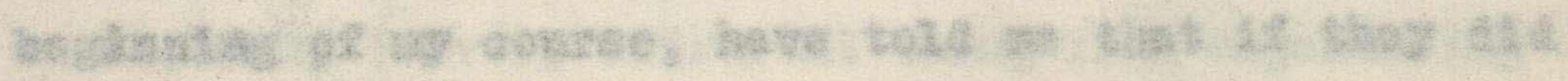

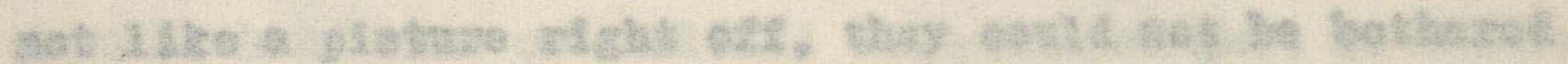




\section{GRADING OF PTCTURES}

In this thesis the writex does not give an idesl syllabus for teachers to I01LOw, Iirstiy because what Is an 1deal syllabus for one teacher w111 not prove aoceptable to another: secondly beouse the making of a syllabus is rightly the prerogative and the duty of the teacher who, moreover, knowe the special olrounstanees of his school end pup1ls; and thirdly beoanse it is extremaly desirable that there should be variety of experience and experiment.

Nevertheless, a few prinolples upon which piotures may be graded are given ss a guide, and my obsorvations and work in the classroom suggests that they will bo of value.

(1) Considerstion of the stage of development of the ch1ldren, their interests and attitudes towards pletwres mat first be made, and this leads to suoh wrestions es:-

Is it possible for the ohildren to see the pleture through the eyes of the artist who pointed it? Is the emotions content which the artist endesvours to srouse In Iine with the emotion which is at the monent, developing in the child? The majorlty of ehildren like or dislike a ploture sccording as it does or does not suit their partiovlar fancy, and frequently ohildren at the beglnning of my course, have told me that if they did not like a pieture right off, they could not be bothered 
to 11ke it at a11. This attitude of mind is engendered In the home, and unless altered, prevents growth and development, for it is as much as to say "I am very we11 setiefied with myself, and, quite Indifferent to the experlenoes and leelings of other people." It is very necessary then, that the emotional content of the pieture is on al1. fours with the emotion which is teveloping in the chila, for it is just this experience and feeling of another person which a ploture can give.

The reason for this is plain. The world itself is a vast panorama, and from 1 t the painter selects his subjeot, not to copy it exactiy, since it would be inpossible for him to do this, even 19 he tried. How eovla he represent, for example, each blade of grass, each leaf upon a tree? The artist represents the subject as he sees 1t, as $1 t$ appee1s to his sympethy or Interest; and if twenty artiats painted the same landseape, the result would be twenty different pictures, difforing according to the wey in which each man had been impressed by the scene; in faot, accoraing to his separate point of view or separate way of seeIng 1t, Influenced by his Individusl experience and feeling. Since no child can include in himself the whole tange of possible experience and feeling, it is through the experienee of others that he can deepen and refine his ovn. If it is this that wo look in piotures to accompltsh, fa very different thing Irom engendering a mere offhand like or aislike) the pletures pust be carefully 
sezected and graded.

A11 piotures are not worth intima te study. We may get inside the artist to Iind that his experience of life is meagre, his feeling commonplace and paltry. There are not a few men of this sort in the occupation of art, just as in every other walk of $11 \mathrm{fe}$, and their pietures, so far as the children themselves are concerned, will be aisappointing. We see this in expdriments on the effects of long time exposute of paris of plotures described on page 54 of this thesis. But among the pietures which have stood the test of time we always find that the fruits of the Artist's experience and feeling are of a kind which makes lasting appeal to the needs of the human heart and mind, and that this fact is one of the causes of their being held in so high esteem. Children can easily be led to appreciate this, providing the pictures are graded and presented to them in accordance with the stage in their emotional development.

(2) The technique of the artist must also be considered, If the eirst tests of the pioture's suitability are satisfactory. The making of a pieture inwolves two processes: a taking in of the impression and a giving out by visible expression; a seeing of the subject with the visual and mental eye, and a communicating of what has been so seen to the visual and mental eyes of others: 
and both these processes are Influenoed by the experience and feeling of the extist and must make their appesi to the ohild. It should be olear that the beauty of the pleture depends much lese upon its subject than upon the artist's conoeption of 1t. Children I flnd, readily appreciate that the grand subject does not of 1 tself make a grand picture, while a very homely one, by the way in which it has been treated, often impresses them profoundy.

The degree of beauty in a pioture depends in fact, upon the feoling for beauty in the artist and upon his power to express 1t. These tw qualifications do not influence the picture separately, but the conception and technique are blended together in the pleture, and as the children ere lead to appreciate pictures these two should be embraced simultaneously. The aim of the study of technlque is certeinly not to prdacee a swarm of indifferent artigts but to help appreciation.

(3) In order to lead the children to appreciate how various$1 y$, at successive times and in diverse countries, different men have concelved of life and have expressed their feeling and experience in piotures, I suggest that they be presented. through a serles of oomparisons, taking into account the two types - extraverts and introverts, wherever this is possible. By this nethod the ohildren may more easily get at the artist's way of seeing in each case, and reach some appreciation of his me thoda.

(4) The course should eover art from the earliest times, 
and should omit no movements or schools of importance. There ean be no justifioation for schemas atill commoniy found which omit large and important parts of the ejeld. of course all parts eannot be treated in the same deta11, and meny will receive a lighter treatment than others. It has been the writers' experienoe that the best way is to cover the whole fleld of piotorial art in the earlier years, leaving the 1 ast year or an adequate part of it for a last broad survey of the modern pictorial art with special reference to those movements which are affecting artists. This plan facilitates the drawing together and systematio organization of the prineiples taught during the earlier years.

(5) Tive order in which the schools of art are seleoted for study must be carefuily thought out so as to provide opportunities for progressive teaching. It is obvious not only that an appreoistion of some sohools and types is more difficult to teach than others, but also that they present aifferent teaching possibilities. Sone teachers may wish to break away from a strictly chronilogical presentstion. It is possible to do this and still to make a syllabus which is in harmony with the principles now being discussed.

(6) Side by side with these studies there should be a delinitely planned eourse of work designed to give pupils first-hand experience of the facts and principles of ereation in the realm of piotorial art. In New 
Zealand there are unfortunately not a large number of art galleries to which teachers may take their clasaes for well-chosen and sultably prepared educationsl $\nabla 1$ ists, but al though the sohools in the maln centree have exceptIonal opportinities in this respect much remains to be done, and too often these visits take the position of "extras" Instead of being an integral part of a syllabus closely related to the woxk done in the school. (7) The syllabus should take note of suiteble opportunlties for correlation with other subjects. The gubject has innumerable points of contact with other subjeots, and whenever opportunities arise netureliy, regard should be had to the work being done in these other subjects. Such opportunitles are especially numerous in history and geography. The correlations should not be forced; they should arise naturally from polnts of contact between syllabuses each of which has been drew up in conformity with the aharateristio development of the particular subject. In addition, the teacher of "Art Apprealation" will make many references to other subjects where such are called for by the metter under a1scuss1on. 
CONCIUSTON

The aim of the wxiter of this thesis has been to investigate a few of the many problems which confront the teacher of the appreciation of one type of pictures in a mixed high school in New Zealand. He has sought to find some of the bed-rock facts upon which the teacher may bulid $h i s$ schemes and his lessons. The thesis is by no means comprehensive of all the problems, and indeed many of the "Key" problems (such as those appertaining to the part that form balance and symmetry, combinations of colours and eyemovements play in the aesthetic enjoyment of pictures) have not been touched upon at all. The subject is perhaps one of the most difficult of all, and has demanded of the student not only wide reading in the psychology of art and of aesthetics, but also careful study of the lives and works of many of the artists themselves. Since he found it impossible to determine the $11 \mathrm{mits}$ of his investigation, he has attempted therefore th make a preliminary survey of parts of the fleld and of some of 1 ts main bearings. While he has endeavoued to draw from his experiments and observations in class-work inferences as to Indications of principles, he attempts no ceneral conclusion as the subject is too fast for a thesis such as this. It is hoped, however, that the teacher who is seeking the underlying principles in the process of appreciation of art (one type) with a view 
to applying them to his work in the classroom, w1ll find much that will be of practical value. Some?

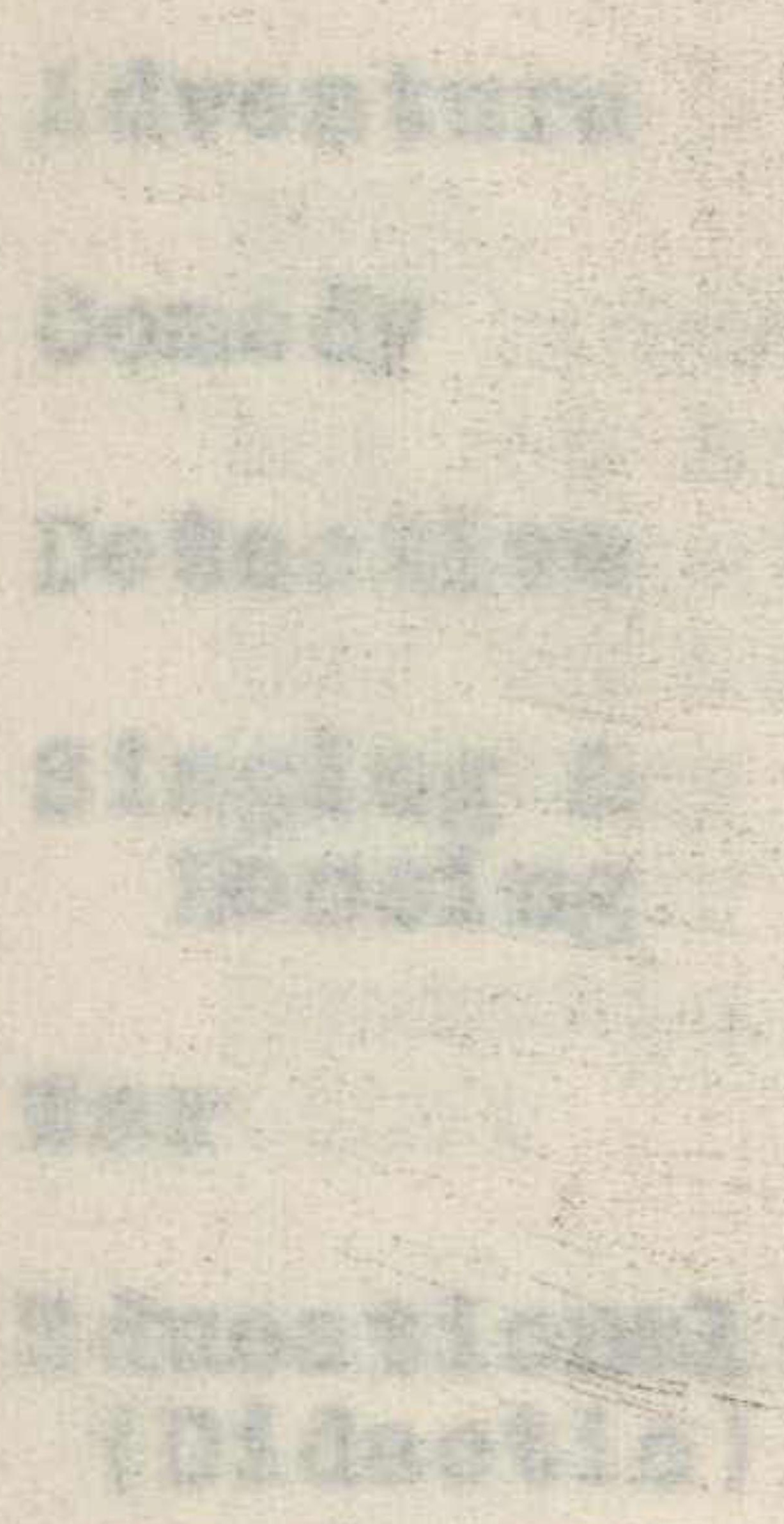

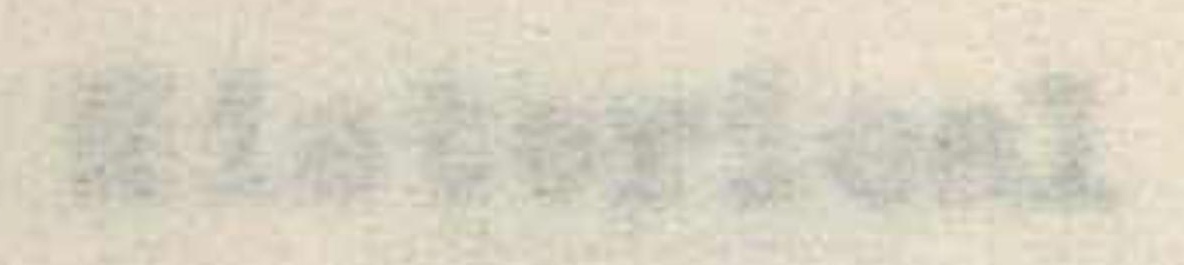

1.5.

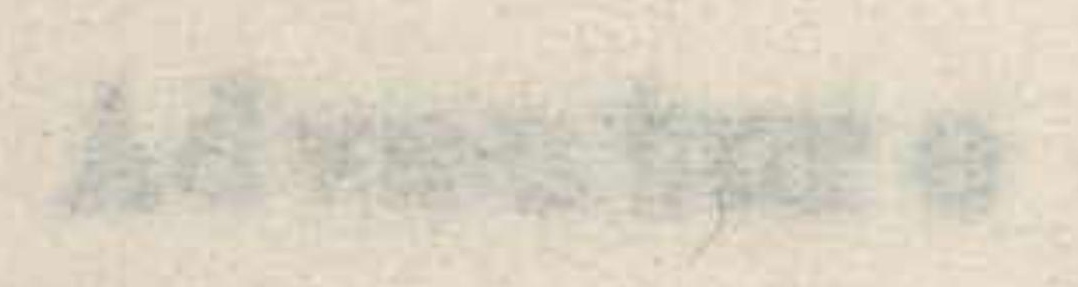

Cosersitis

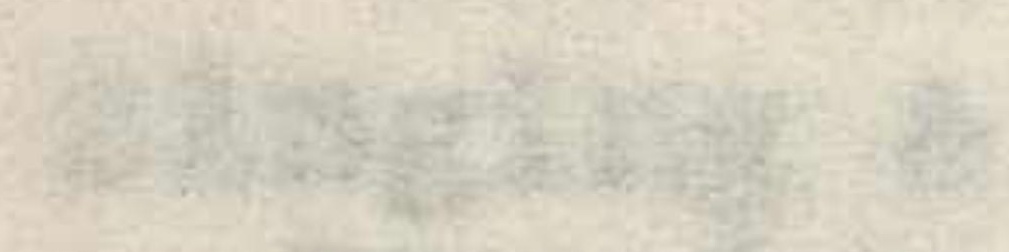

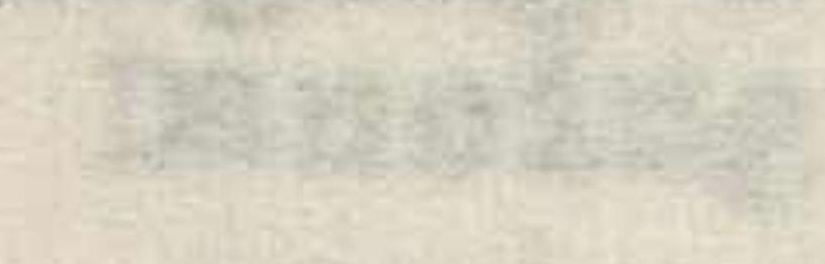

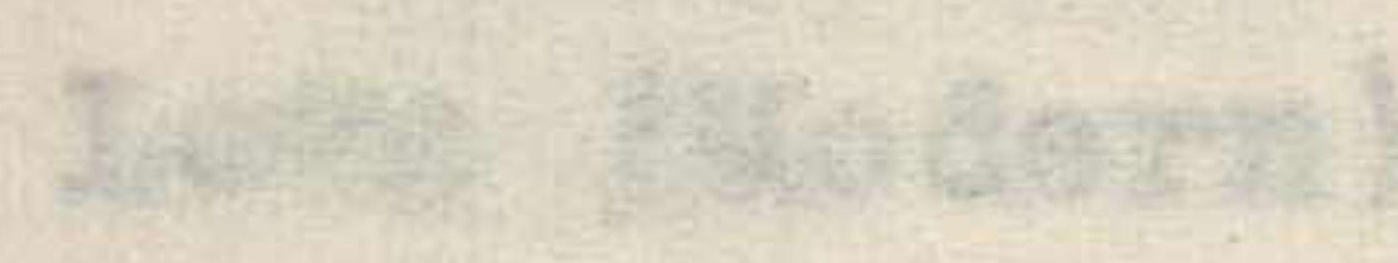

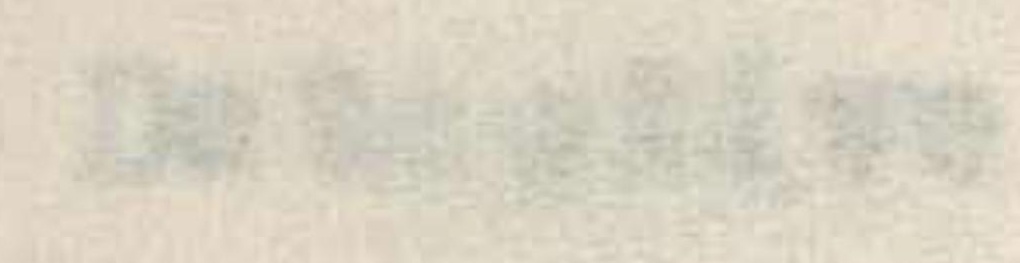

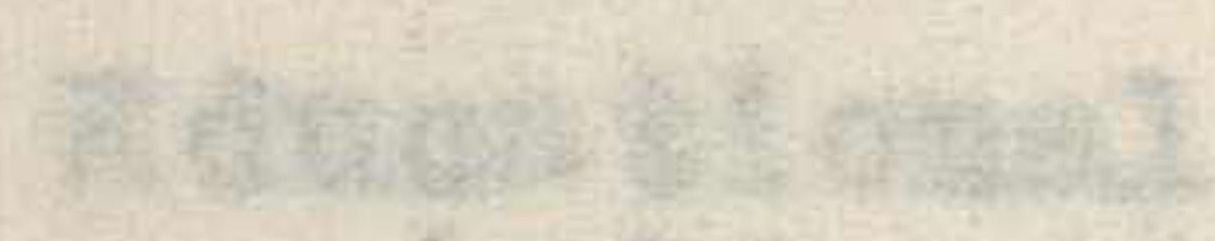

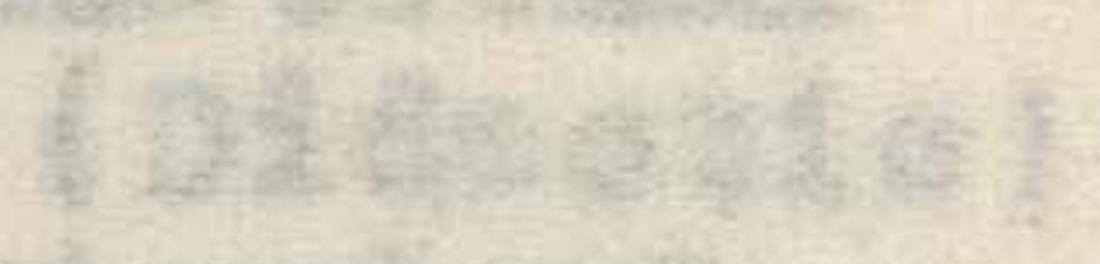

E. $36 \cdot 24 \cdot 20=-2$

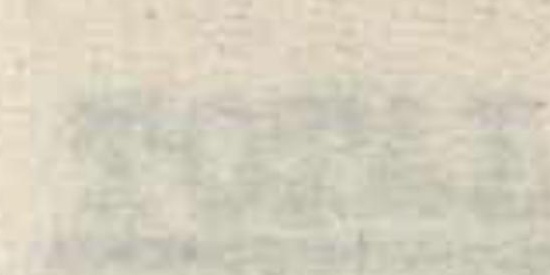




\section{TA B I E $\mathcal{N}_{0}$ I.}

FAVOURI TE TALKING PI CIURES

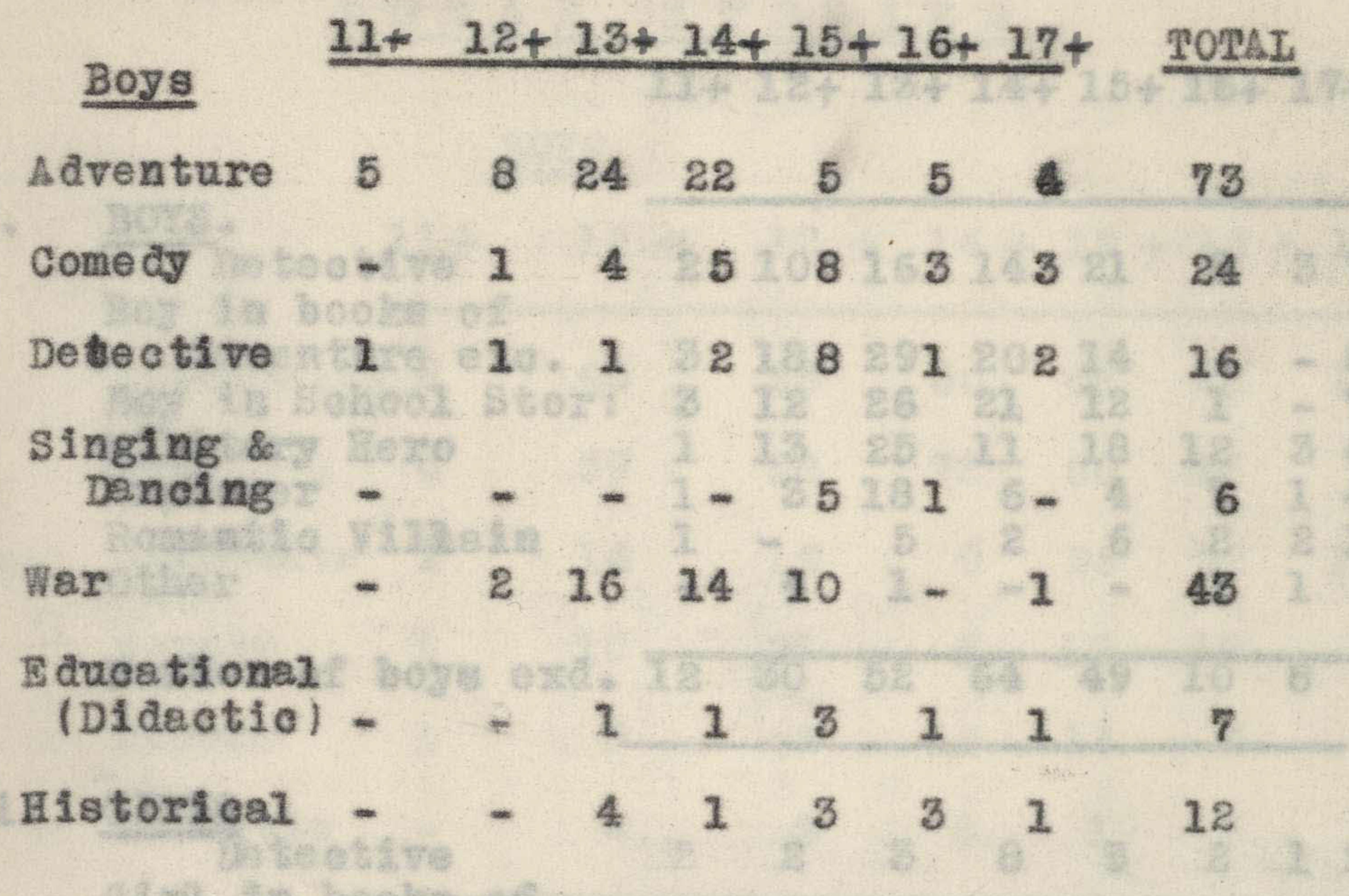

\section{Girls}

$\begin{array}{lllllllll}\text { Adventure } & - & 8 & 18 & 10 & 16 & 8 & 2 & 62\end{array}$ Comeây $\quad-\begin{array}{llllllll}1 & 5 & 9 & 2 & 1 & 2 & 20\end{array}$

$\begin{gathered}\text { singing \& } \\ \text { Daneing }\end{gathered}$
Love (Modern) $51210-1$ - 128 Detective of $-1,3-1=30-35$

Bduca tional (Didactio) Historical

$1-3---4$

$\begin{array}{lllll}-264 & \end{array}$ 


\section{T A B I B $\eta_{0} 2$}

IDEAI CAARACTER RROM ANY BOOK OR POPM

$11+12+13+14+15+16+17+20 t .10$. of

diff.

charac

1. BOYS.

Detective

Boy in books of

edventure ete.

$\begin{array}{llllllllll}2 & 10 & 16 & 14 & 21 & 8 & 3 & 74 . & 5\end{array}$

$\begin{array}{llllllllll}3 & 18 & 29 & 20 & 14 & - & -84 & 21\end{array}$

Boy in School Stor:

inilitary Hero

Explorer

$\begin{array}{llllllll}3 & 12 & 26 & 21 & 12 & 1 & -75\end{array}$

10

$\begin{array}{rrrrrr}1 & 13 & 25 & 11 & 18 & 12 \\ 1 & 3 & 18 & 6 & 4 & 7\end{array}$

383

12

Romantic Viliajn

other

14180140

$1-522 \quad 6 \quad 2 \quad 218$

$-41--117$

Number of boys exd. 12 30 52 $64 \quad 49 \quad 10 \quad 8$

11. GIRIS

Detective

Girl in books of

adventure

Girl in historieal

Boy in books of

$$
\text { novels }
$$

$$
\text { ¿dventure }
$$

Girl in school stories

Boy in school stories

Military hero

Nurse

Bxplorers

other

$\begin{array}{lllllllll}2 & 2 & 3 & 8 & 5 & 2 & 1 & 21 & 5\end{array}$

$\begin{array}{lllllll}10 & 12 & 29 & 17 & 12 & -80 & 20\end{array}$

$\begin{array}{llllllll}1 & 3 & 8 & 7 & 5 & 2 & 26 & 5\end{array}$

$\begin{array}{lllllllll} & 75 & 7 & 3 & 12 & 1 & -28 & 20\end{array}$

$\begin{array}{llllllll}12 & 14 & 17 & 12 & 13 & -68 & 17\end{array}$

$20107-2140 \quad 6$

$\begin{array}{lllllllll}3 & 11 & 12 & 15 & 2 & 1 & 44 & 8\end{array}$

$191715-143$ 2

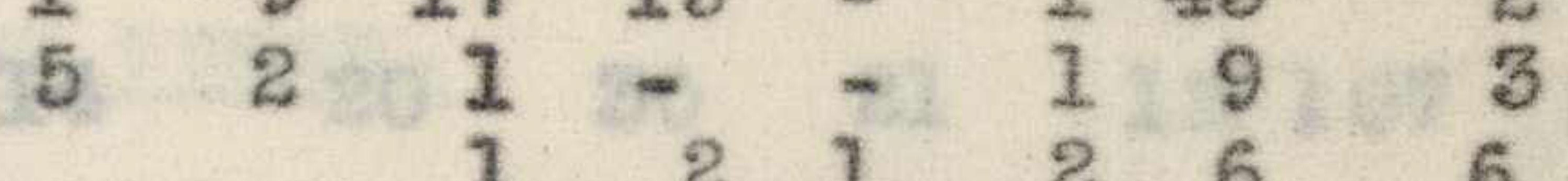

Number of girls exd. $2248 \quad 60 \quad 3918 \quad 6$ 


\section{TABIE $\eta_{0} 3$}

\section{IDEALSIORIES}

BOYS

\begin{tabular}{|c|c|c|c|c|c|c|c|c|c|}
\hline thes & $11+$ & $12+$ & 13 & $+14+$ & 15 & $+16+$ & & & $\begin{array}{l}\text { t.IINo, } \\
\text { Chos }\end{array}$ \\
\hline Adventure. & 8 & 45 & 38 & 50 & 42 & 25 & 12 & 220 & 96 \\
\hline School & 4 & 39 & 58 & 72 & 60 & 36 & $\eta$ & 276 & 74 \\
\hline Detective & 1 & 14 & 19 & 9 & 26 & 32 & 10 & 1.11 & 57 \\
\hline Nove1s & 1. & 10 & 21 & 48 & 17 & 18 & 6 & 79 & 50 \\
\hline Humour & 1. & $5^{20}$ & 2 & 2012 & 14 & 3 & 2 & 39 & 18 \\
\hline Didactie & - & $=-2$ & 4 & $6 \quad 8$ & 1 & -3 & 1 & 17 & 6 \\
\hline
\end{tabular}

\section{GIRTS}

Adventure

School

Detective

IIovels

Humour

Didactie

Number chosen
42

32

10

$$
\begin{array}{llll}
46 & 53 & 45 & 28
\end{array}
$$

$\begin{array}{llll}60 & 76 & 80 & 41\end{array}$

$\begin{array}{lll}14 & 20 & 30\end{array}$

$21 \quad 12107 \quad 53$ $\begin{array}{lllllll}8 & 18 & 25 & 31 & 10 & 92 & 61\end{array}$ $\begin{array}{lllllll}6 & 9 & 14 & 5 & 8 & 42 & 17\end{array}$ 6

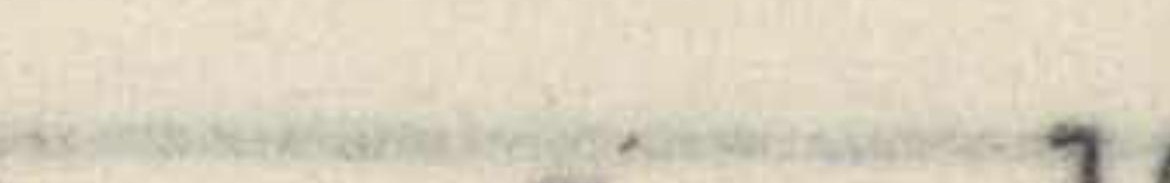
\begin{tabular}{lllll}
16 & 6 & 6 & 34 & 16 \\
\hline
\end{tabular}

49




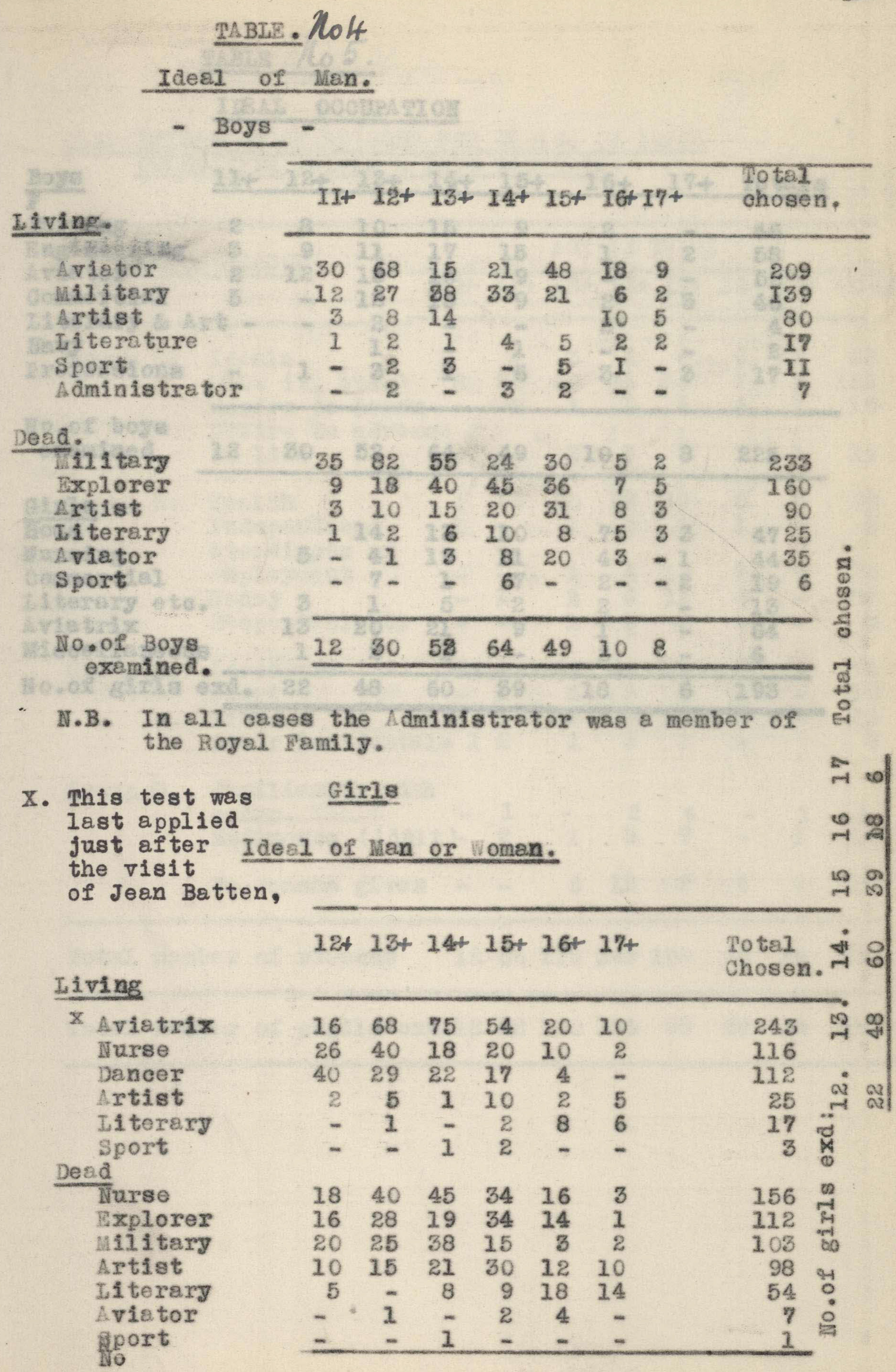


TABLE No5.

\section{IDEAL OCCUPATION}

Boys

$11+12+13+14+15+16+17+$ rotals

Farming

Engineering

Aviator

$\begin{array}{llll}2 & 8 & 10 & 15\end{array}$

Commereia?

$2-46$

$\begin{array}{lll}1 & 2 & 58\end{array}$

conmercial

Navy

$512 \quad 13 \quad 16$

profossions

No. 01 boys

examined.

\begin{tabular}{llllllll}
12 & 30 & 52 & 64 & 49 & 10 & 8 & 225 \\
\hline
\end{tabular}

Giris

Home

Nursing

Commerolal

Literary etc.

Aviatrix

MIsce1laneous

$5 \quad 1$

$\begin{array}{lll}14 & 13 & 10\end{array}$

-

- 52

- -

21

$\begin{array}{lll}2 & 3 & 46\end{array}$

$2-4$

$\begin{array}{llll}-1 & \frac{1}{3} & \overline{1} & 1 \\ \end{array}$

$\overline{3} \quad \overline{3}$

2

17

II 0.01 girls

$\begin{array}{rrr}7 & 19 & 11 \\ 7 & 1 & 7\end{array}$

$\begin{array}{llll}3 & 1 & 5 & 2\end{array}$

$\begin{array}{rrrrrr}3 & 1 & 5 & 2 & 2 & - \\ 13 & 20 & 21 & 9 & 1 & -13 \\ 13 & 2 & 1 & - & 2 & -64\end{array}$

\begin{tabular}{rrrrrrrr}
1 & 2 & 1 & - & 2 & - & 6 \\
\hline
\end{tabular}




\section{maus No 6 -}

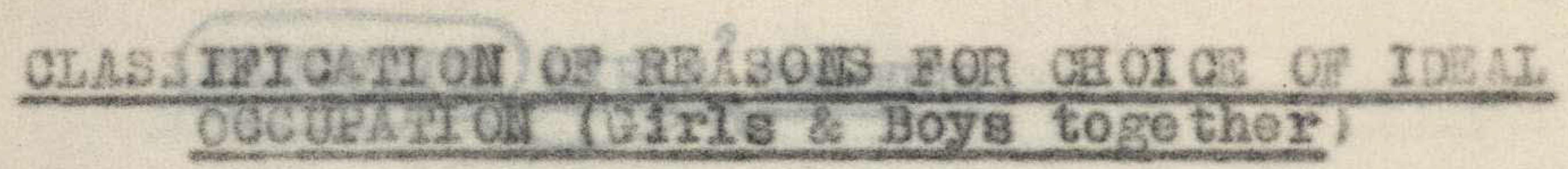

MYPE OP REASON

AGE III XIRS

$12+12+13+14+15+16+17+$ To601

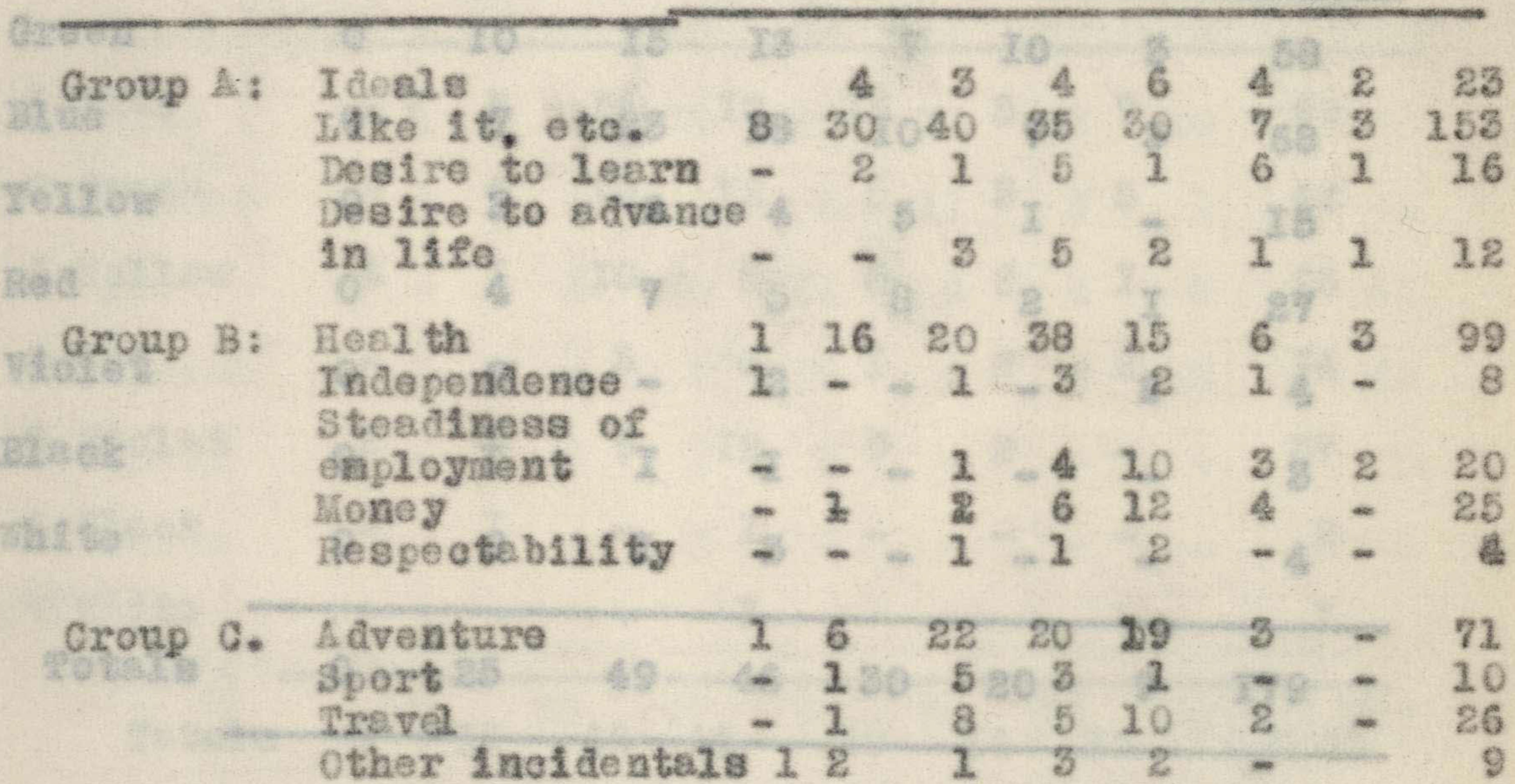

Groug D. Fand11arify with

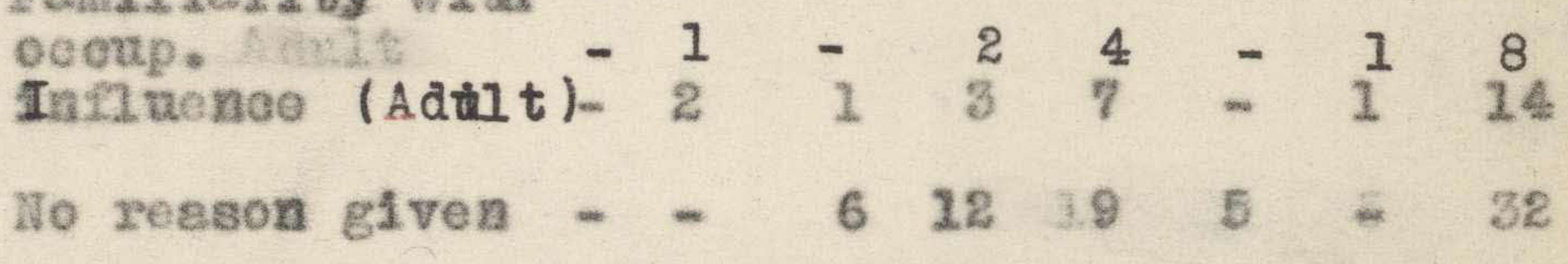

Total number of roesons

$12 \quad 66 \quad 115 \quad 149132 \quad 48 \quad 14 \quad 530$

Tote1 number of pup11s exả.12 $52 \quad 100 \quad 124 \quad 88 \quad 28 \quad 14 \quad 418$ 
Yable noy.

FA VOURITIS GIRLS? COL.OURS.

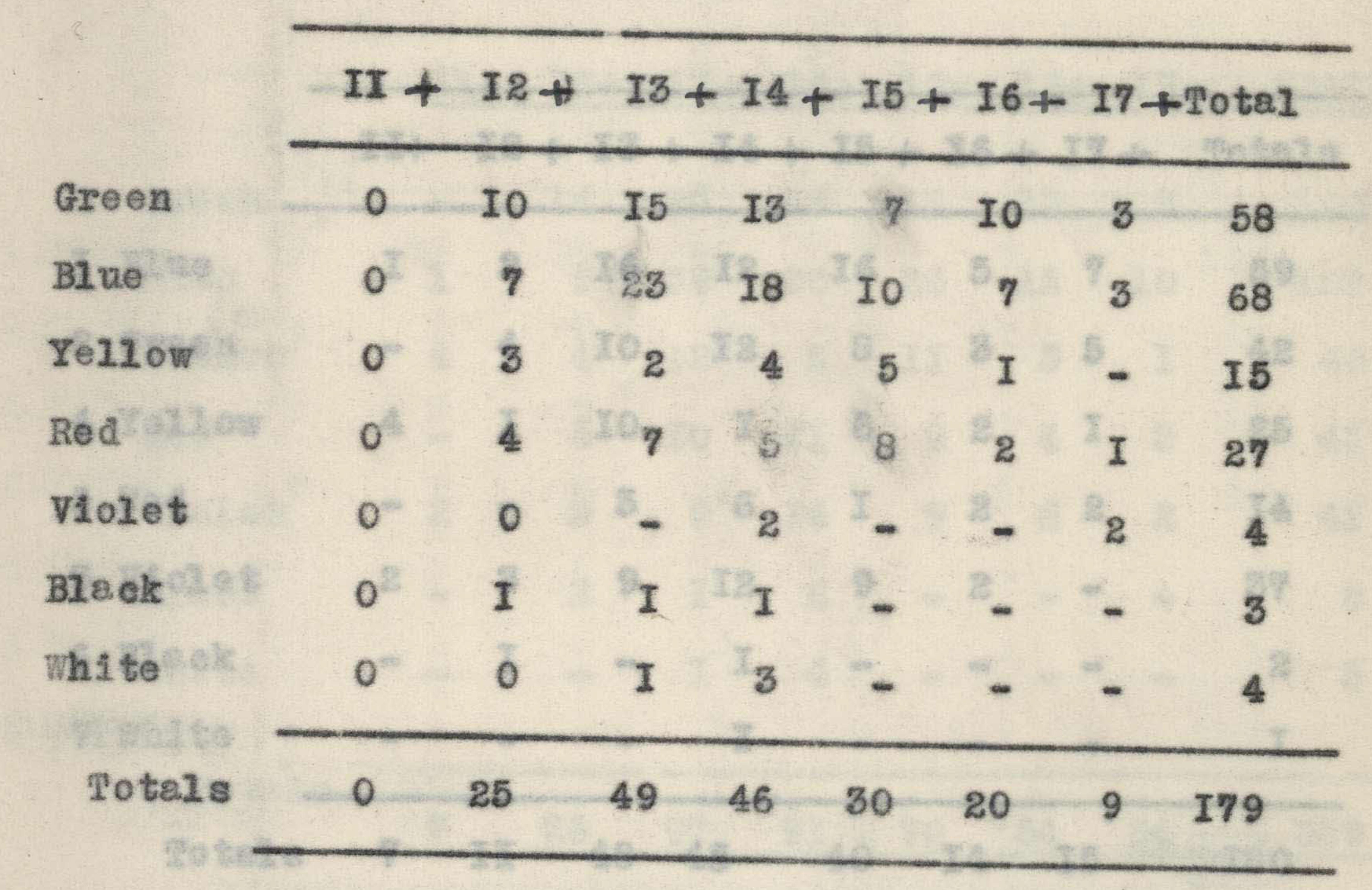


Table 108.

101

COLOURS PREFERRED MUST BY BOYS.

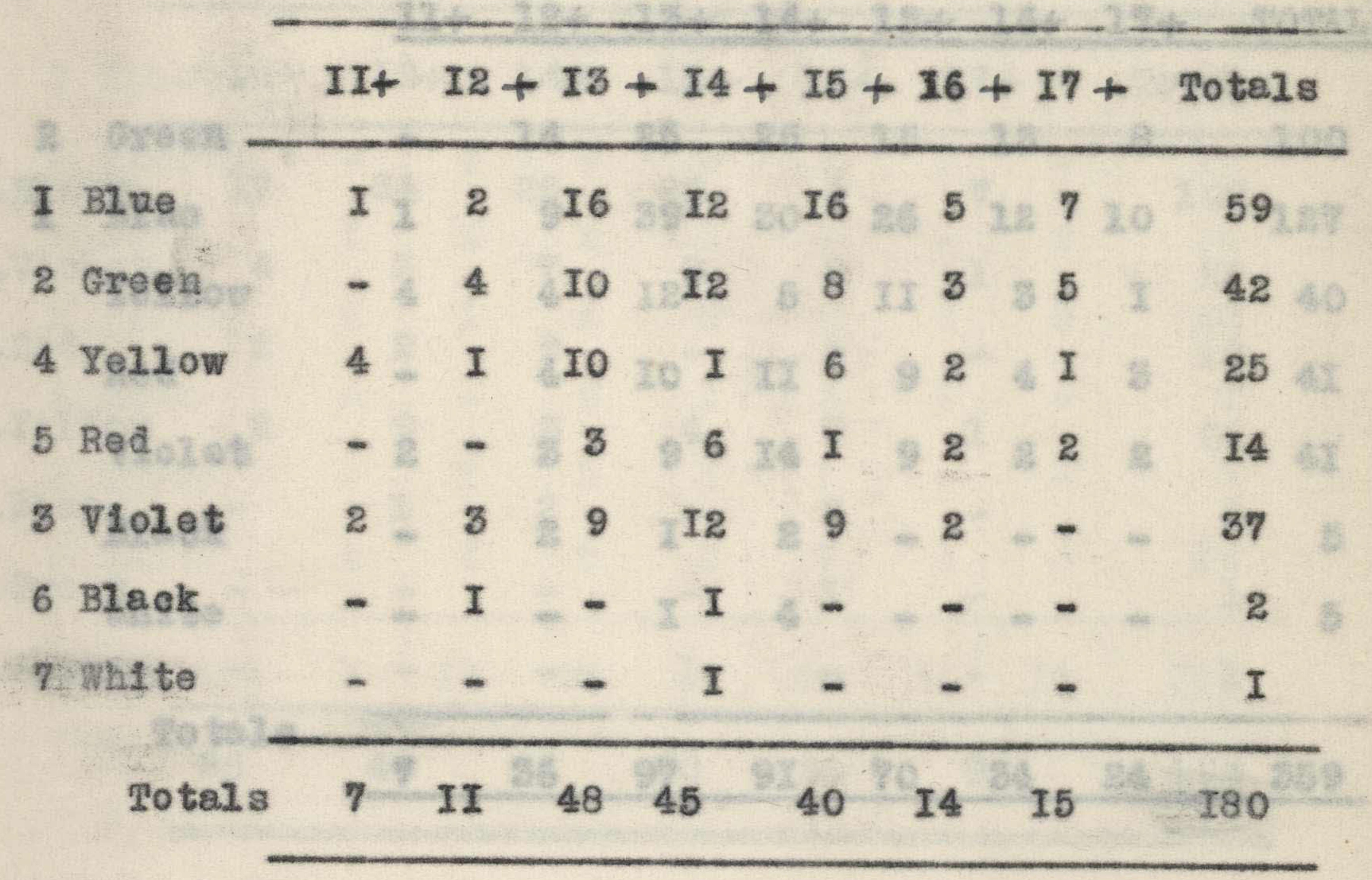


Table No 9.

102

MAVORRTTS coLours

GIRTS AUD BOYS COIBIWD

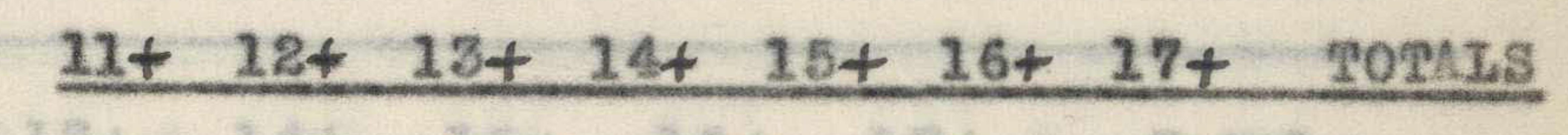

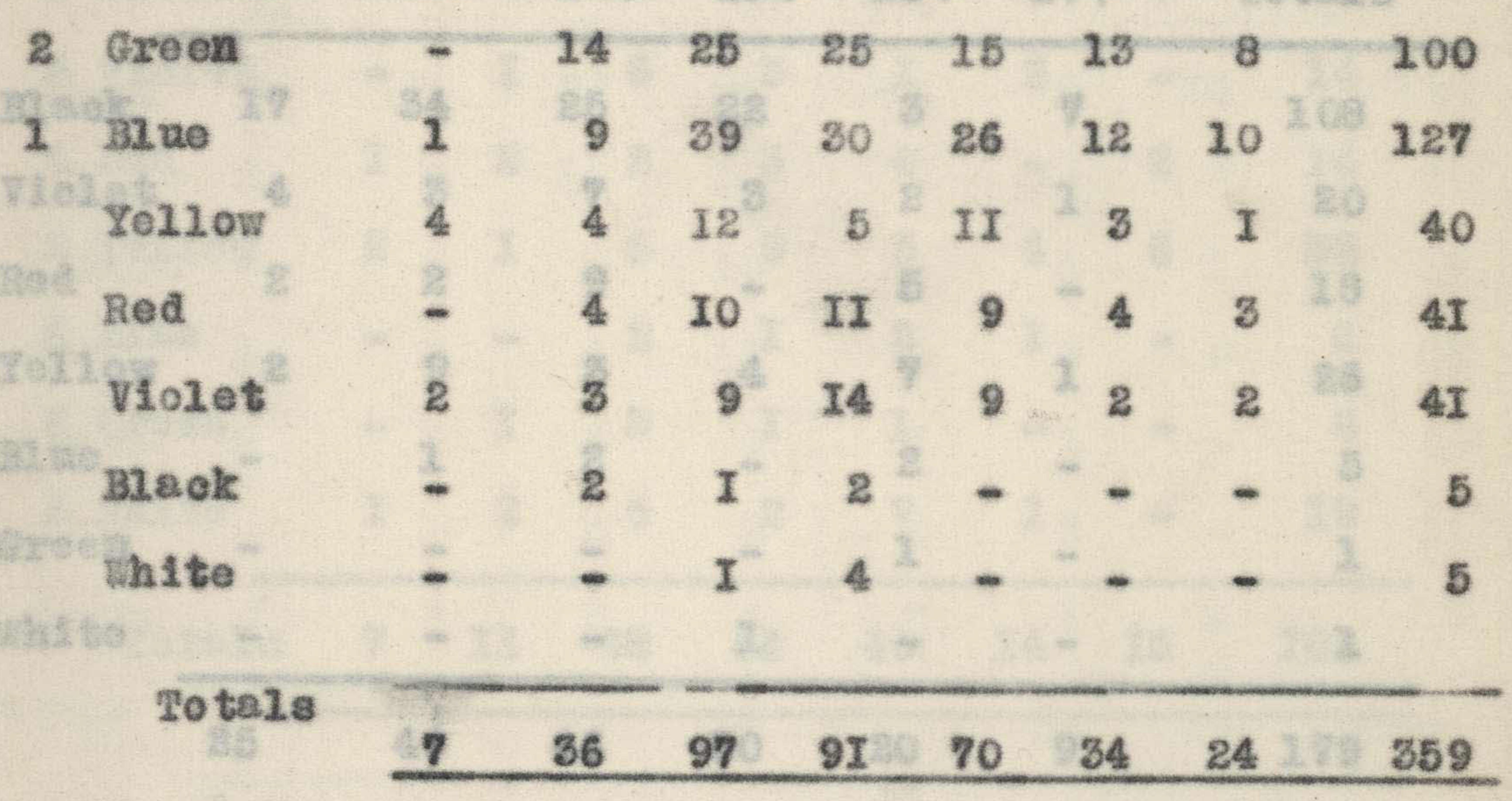


103

Iable 1010

COLOURS IIEAST FAVOURED BY GIRLS

\begin{tabular}{lrrrrrrrr} 
& & $12+$ & $13+$ & $14+$ & $15+$ & $16+$ & $17+$ & Totals \\
\cline { 2 - 8 } 1.Black & 17 & 34 & 25 & 22 & 3 & 7 & 108 \\
3.Violet & 4 & 3 & 7 & 3 & 2 & 1 & 20 \\
4.Red & 2 & 2 & 9 & - & 5 & - & 18 \\
2.Yellow & 2 & 9 & 3 & 4 & 7 & 1 & 26 \\
5.Blue & - & 1 & 2 & - & 2 & - & 5 \\
6.Groen & - & - & - & - & 1 & - & 1 \\
6.White & - & - & - & - & 1 & - & - & 1 \\
\cline { 2 - 9 } & 45 & 49 & 46 & 30 & 20 & 9 & 179 \\
& & &
\end{tabular}


Liable No 11.

104

COLOURS FAVOURED LEAST BY BOYS.

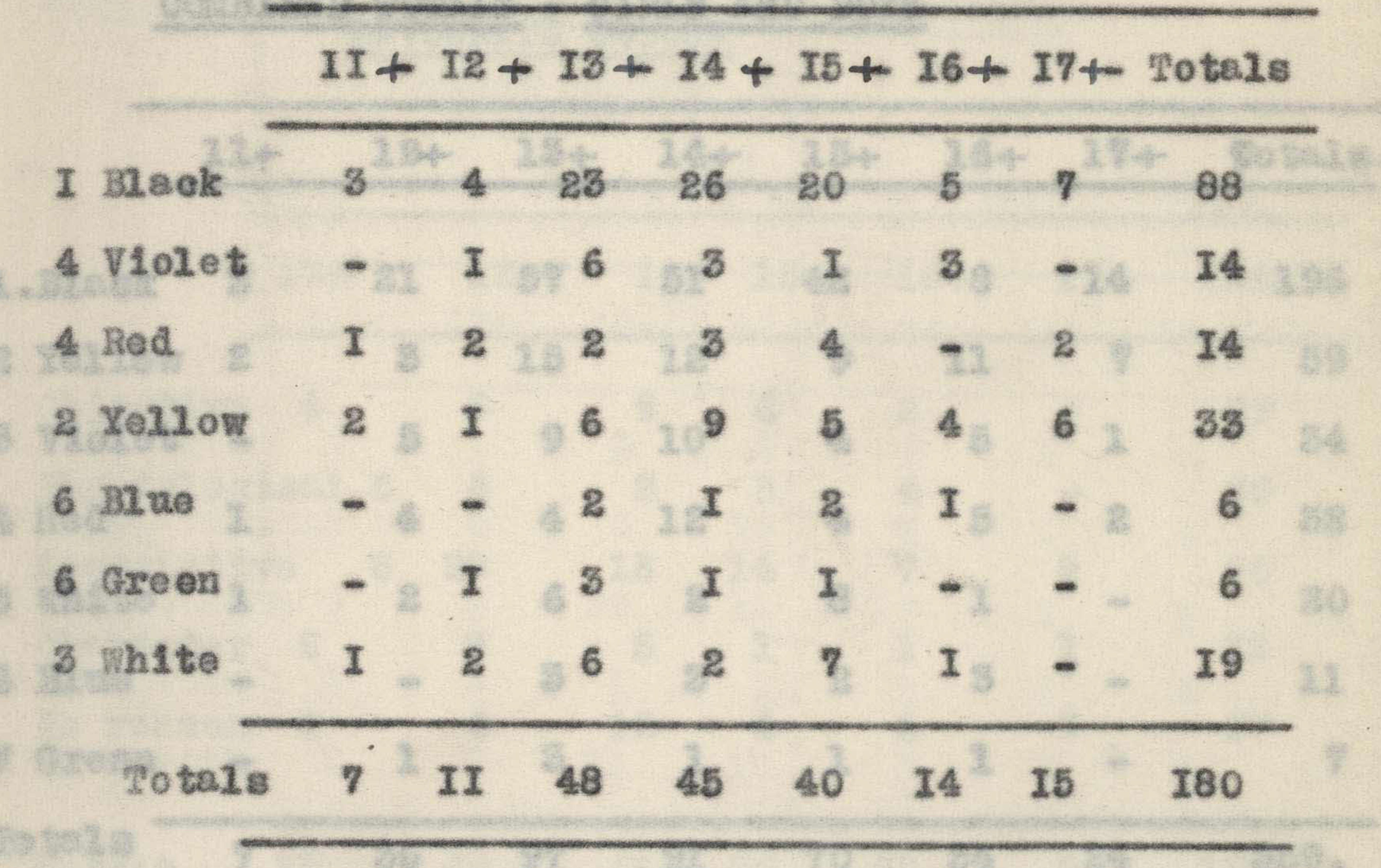




\section{Lable to 12.}

\section{GOLOURS FA VOURED LEAST}

\section{VOUBINSD TORALS - GIRLS AND BOXS}

$11+12+13+14+25+16+17+20$ tels.

\begin{tabular}{lrrrrrrrr} 
1. Bleak & 3 & 21 & 57 & 51 & 42 & 8 & 14 & 196 \\
2 Jellow & 2 & 3 & 15 & 12 & 9 & 11 & 7 & 59 \\
3 Vlolot & - & 5 & 9 & 10 & 4 & 5 & 1 & 34 \\
4 Red & 1 & 4 & 4 & 12 & 4 & 5 & 2 & 32 \\
5 thite & 1 & 2 & 6 & 2 & 8 & 1 & - & 20 \\
6 Blue & - & - & 3 & 3 & 2 & 3 & - & 11 \\
7 Grean & - & 1 & 3 & 1 & 1 & 1 & - & 7 \\
Totals & 7 & 36 & 97 & 91 & 70 & 34 & 24 & 3590 \\
\hline
\end{tabular}


Table No 13.

CLASSIFICATION OF GIRLS' REASONS FOR CHOOSING

FAVOURITE COLOUR

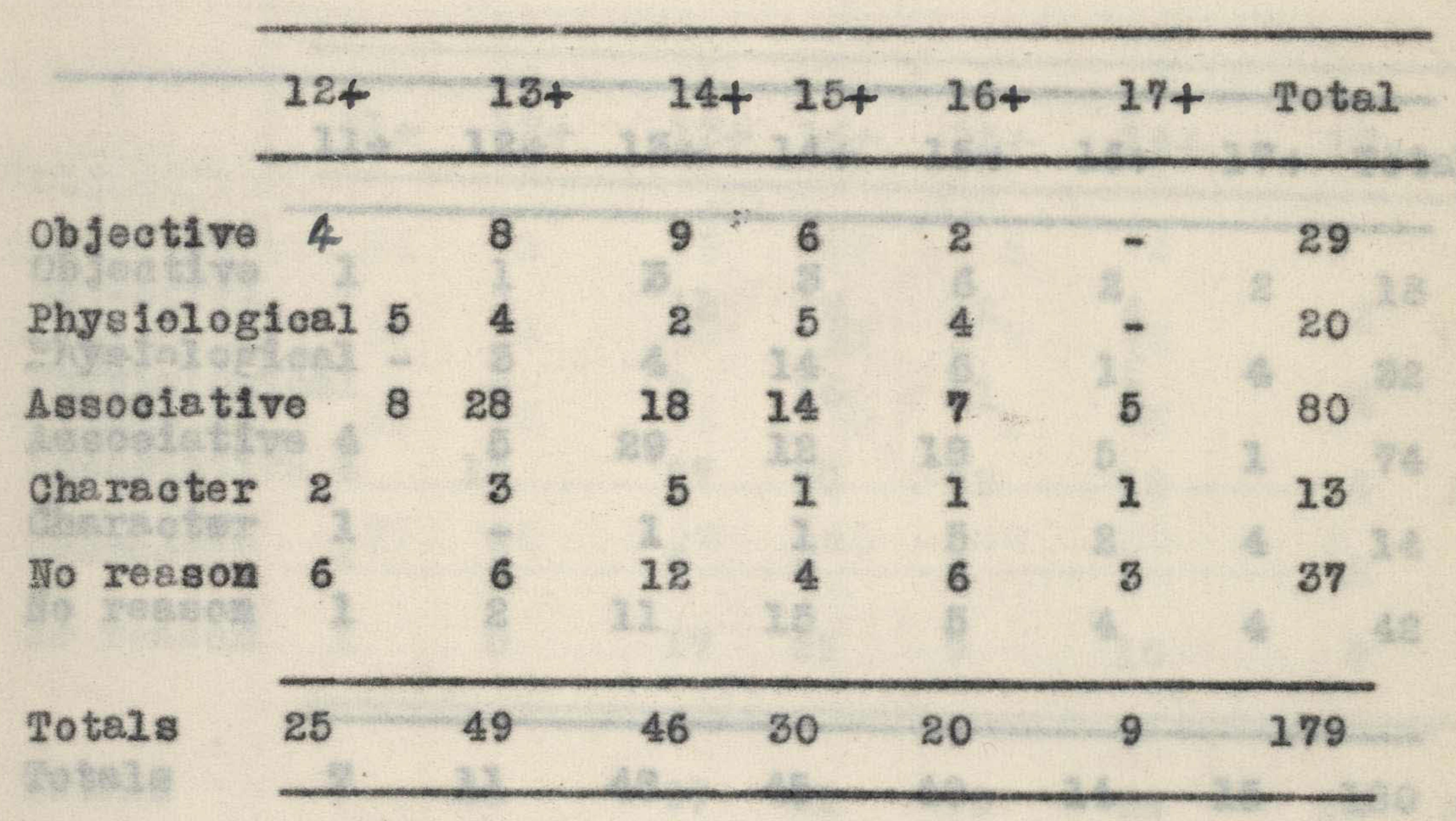


Table No It

CLASSIFICATION OR BOYS' REASONS BOR CHOOSING

EA VOURITE COLOUR

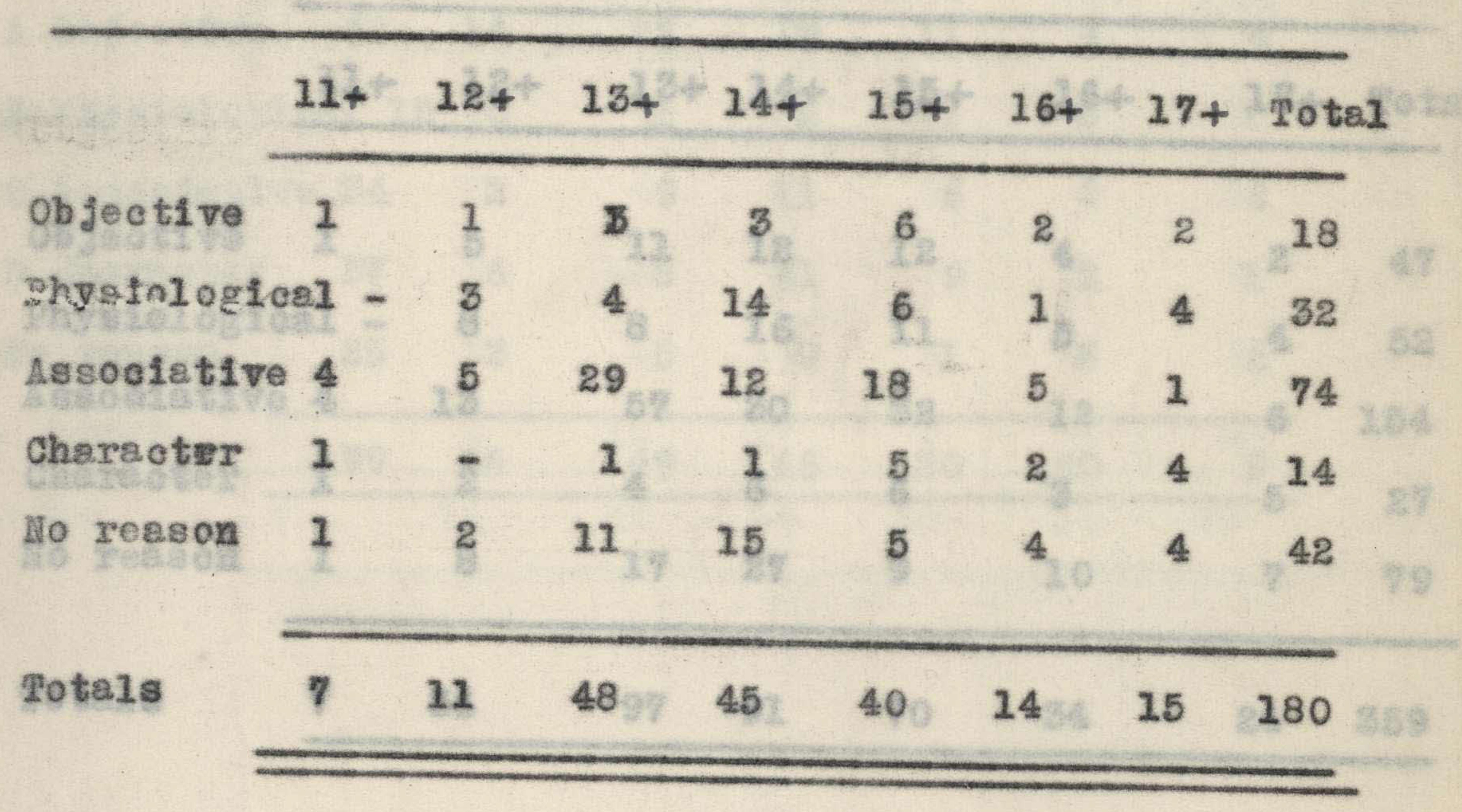


Lable No 16.

108

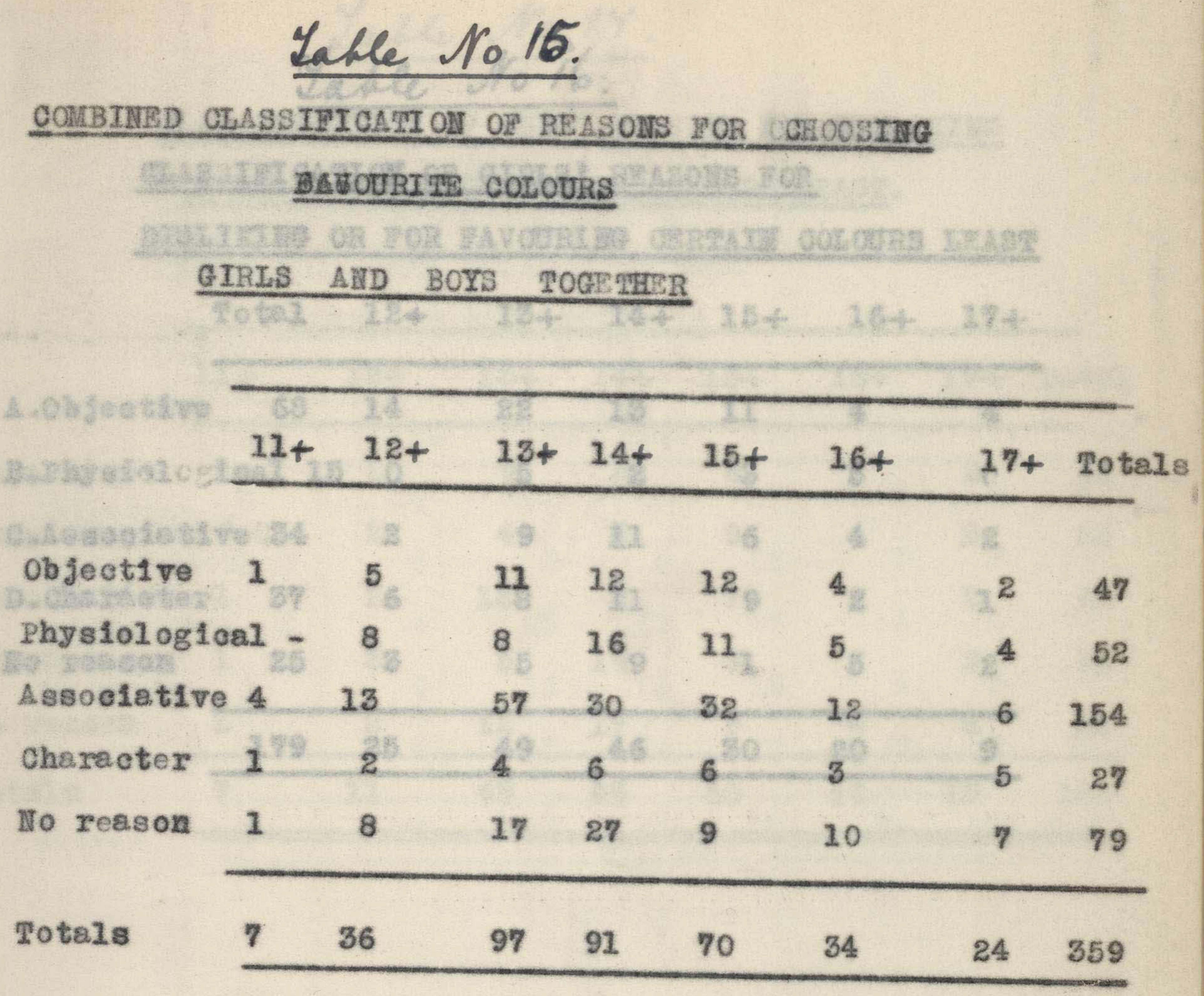


109

Yable No16.

GIASSIHICATIOH OR GIRES' REASOIS HOR

DISLIKIMG OR FOR FAVOURIMG CERTAIII COLOURS LEAST

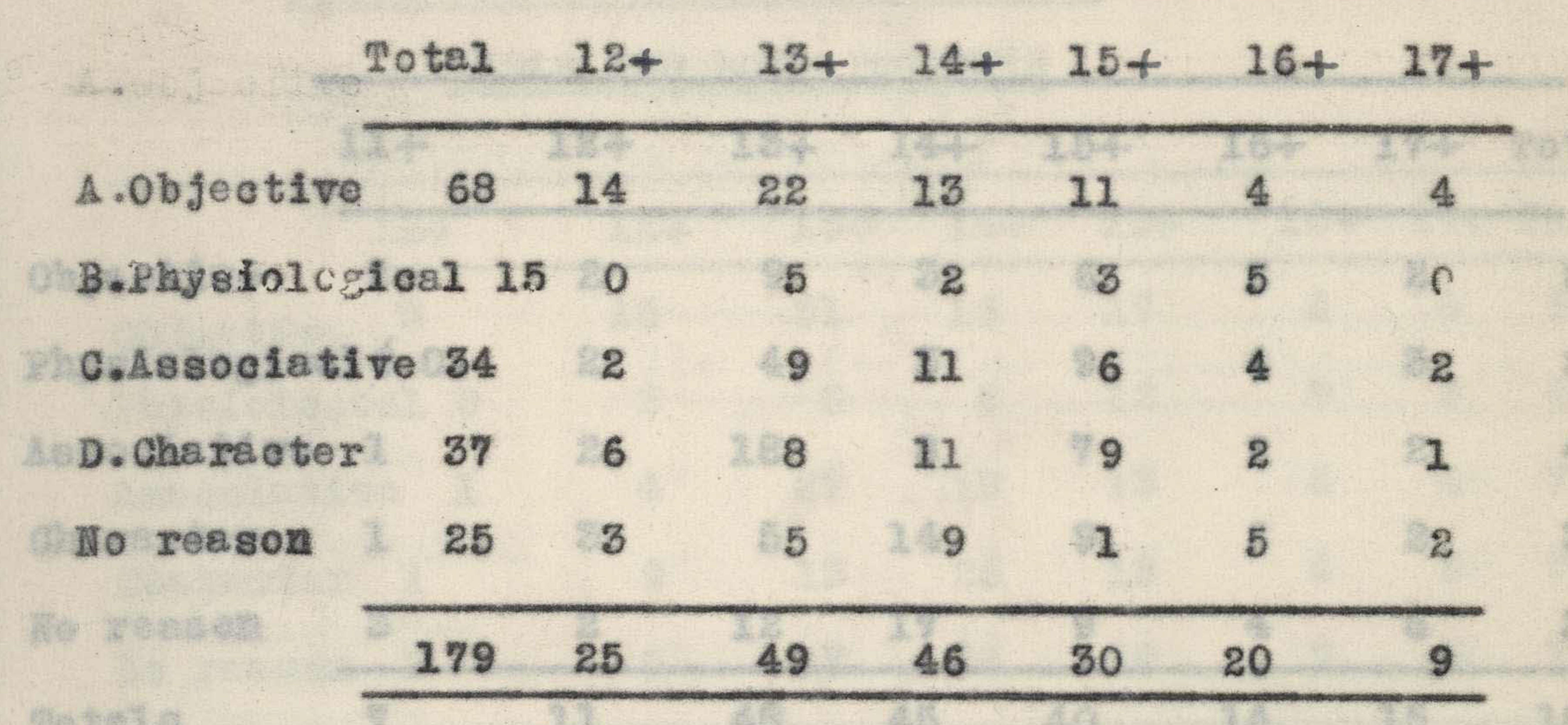




\section{Yable $\mathscr{N}_{0} / 4$.}

CIASSIBICATI ON OF BOYS * REASONS FOR DISLIKING

OR FOR FAVOURI MG CERTAIII COLOURS LEAST.

$$
11+12+13+14+15+16+17+\text { Total }
$$

$\begin{array}{lllllllll}\text { Objective } & 2 & 2 & 9 & 3 & 6 & 2 & 2 & 26\end{array}$

Physiologicalo 0. $2 \quad \begin{array}{lllllll}4 & 3 & 9 & 4 & 3 & 25\end{array}$

\begin{tabular}{lrrrrrrrr} 
Associstive & 1 & 2 & 18 & 8 & 7 & 2 & 2 & 40 \\
Character & 1 & 3 & 5 & 14 & 9 & 2 & 2 & 36 \\
No reason & 3 & 2 & 12 & 17 & 9 & 4 & 6 & 53 \\
\cline { 2 - 9 } Totals & 7 & 11 & 48 & 45 & 40 & 14 & 15 & 180 \\
\hline
\end{tabular}


Table tro 18.

COMBINED CLASSIRICATION OF REASONS FOR

IEAST FAVOURTHG CERTATA COLOURS

GIRLS AND BOYS TOGE THER

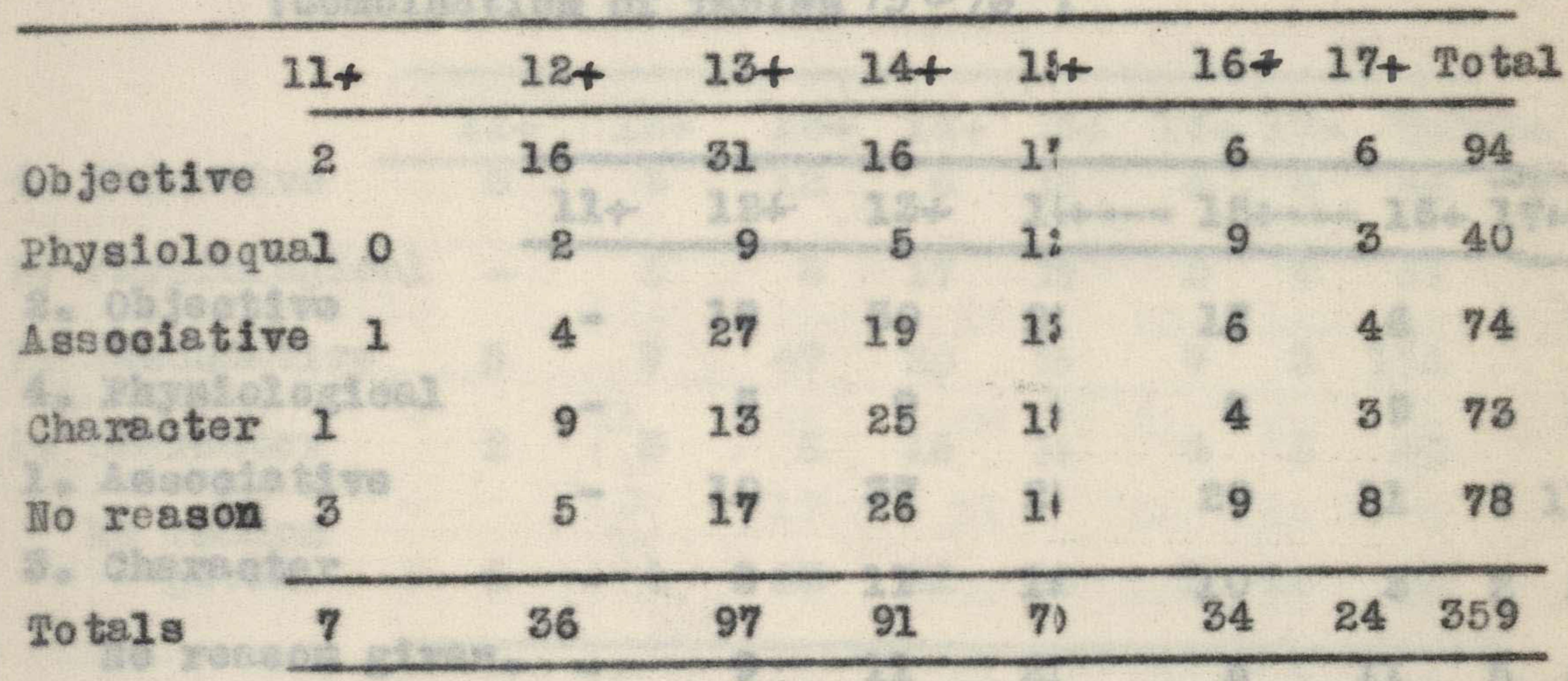


$1 / 2$

Table tro 19.

COIBINED CLASSIEICATI OI OR REASOISS BOIH FOR

IIIIIIG AID DISLIKIIV GERPAII COLOURS

GIRLS

(Combination of Tables $13 \propto 16$ )

2. Objective

4. Physiological

1. Assoelative

3. Character

IIo resson given.

Totale

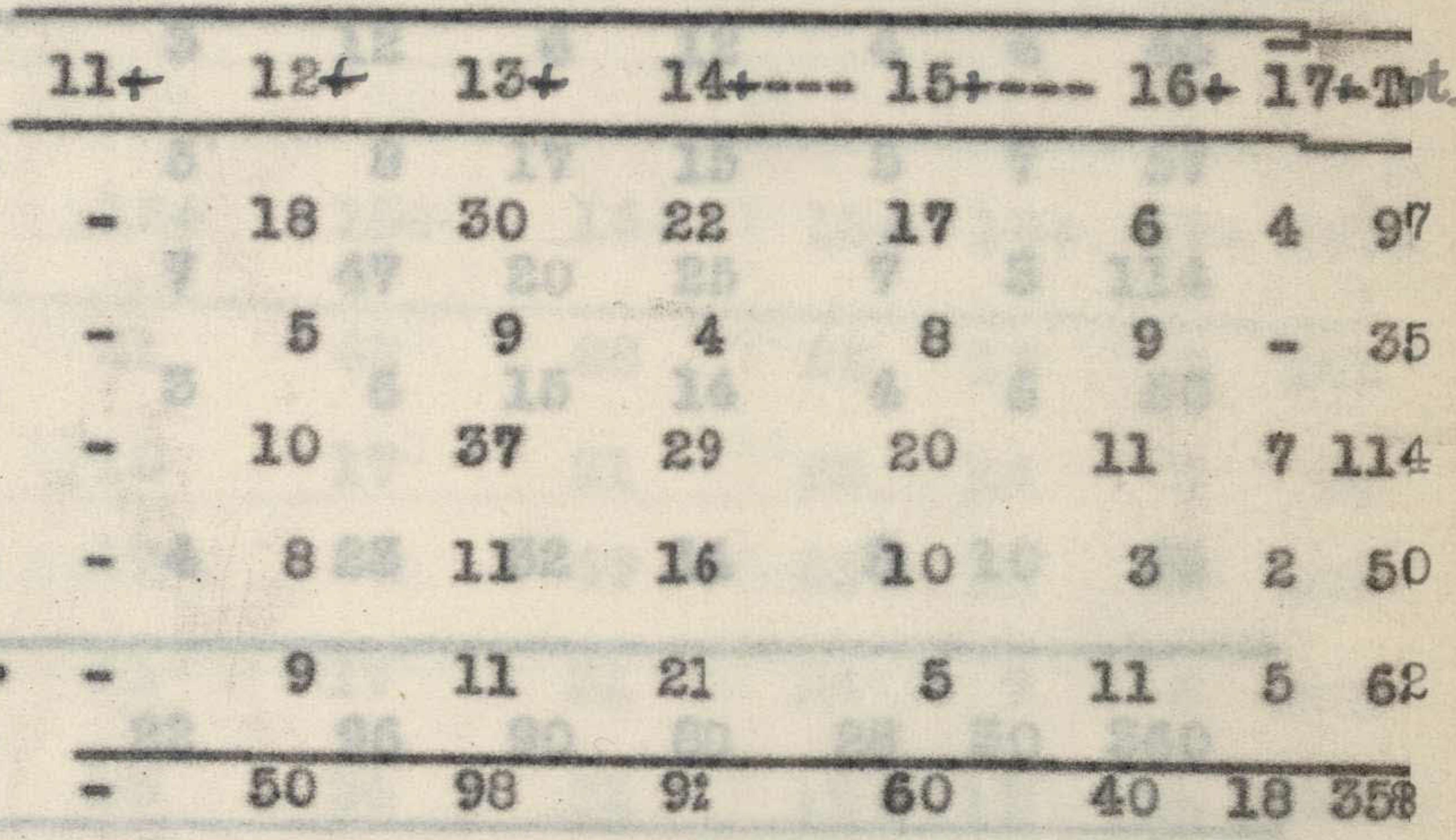


113

Table to 20.

COMBINED CLASSTRICAMTON OF REASONS

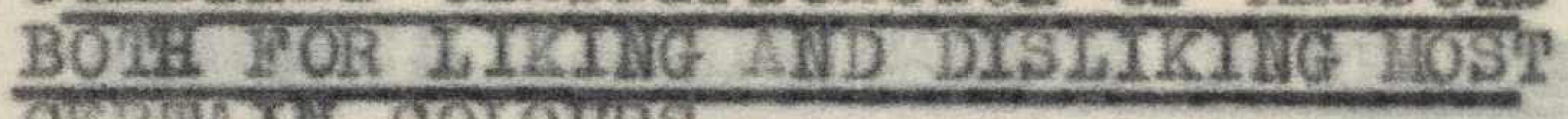

GERM CI COLOURS.

BOYs

(Combination of Tables (4) and Is)

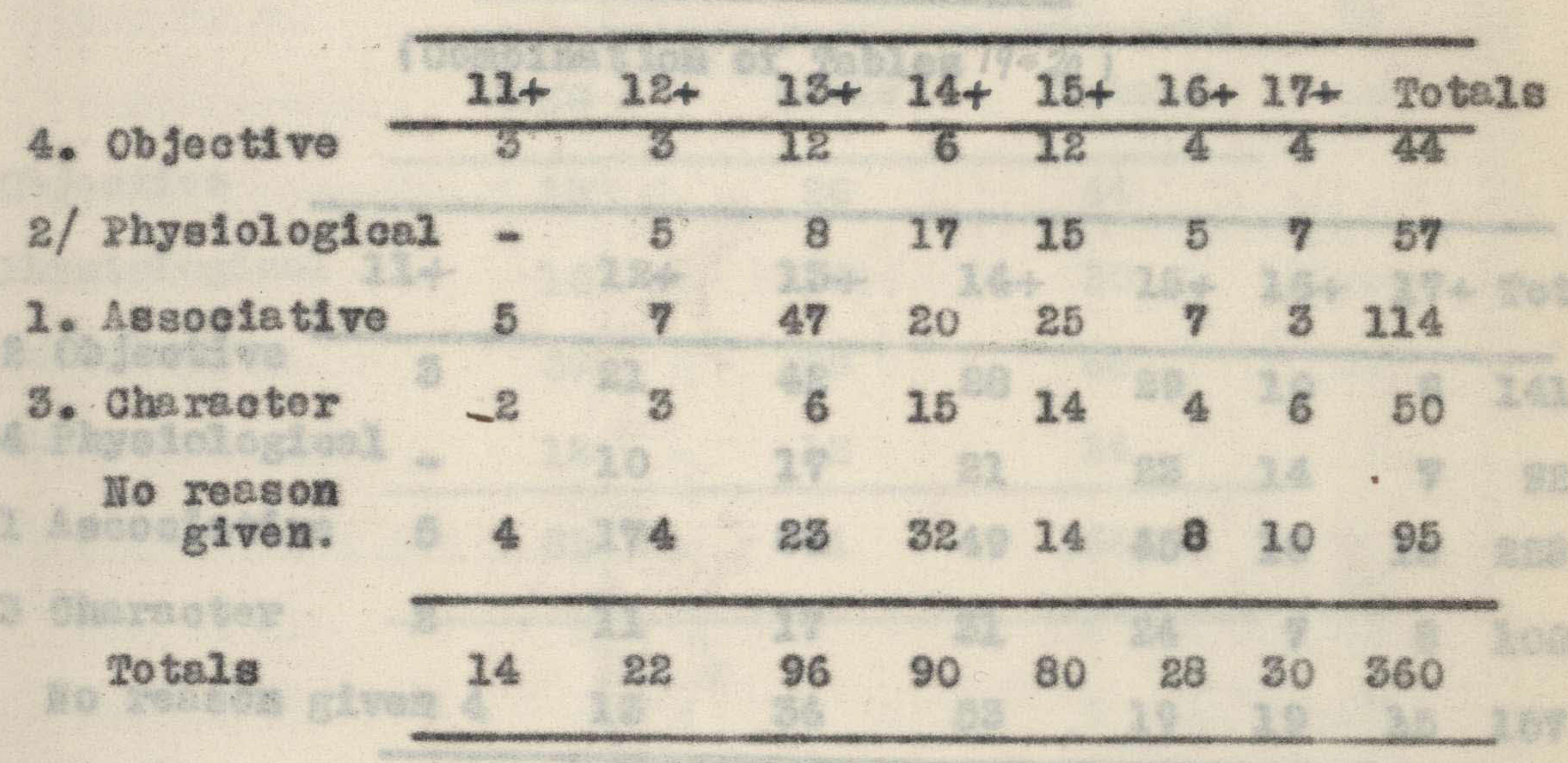

VICTORIA UNIVERSITY OF WEIIRETON LIBRARY, 


\section{Zate to 21.}

\section{COUBTUED CLASSTET CAMTON OS REASONS BOTH}

HOR LIKTWE AND DISJIKIING HOSP OERTIII

COLOURS

\section{BOXS AID GIRTS TOGE THER}

(Combination of Pables 19+20)

Ghatontedre.

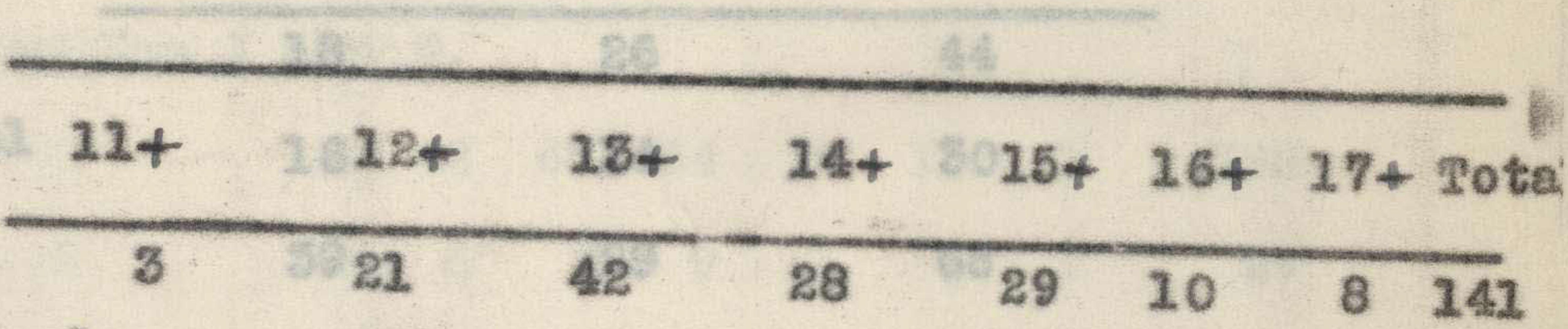

2 objective

2

4 Phys 1 ologi oal

1 Associative

$-10$

17

21

23

$\begin{array}{llll}23 & 14 & 7 & 92\end{array}$

3 Character

17

84

49

45

18

31

247

$10 \quad 228$

I0 reason

Totals

$\begin{array}{lll}2 & 11 \quad 17\end{array}$

\begin{tabular}{cccccccc}
\hline 14 & 13 & 34 & 53 & 19 & 19 & 15 & 157 \\
\hline
\end{tabular}

\begin{tabular}{cccccccc}
\hline 14 & 13 & 34 & 53 & 19 & 19 & 15 & 157 \\
\hline
\end{tabular}


$1 / 5$

Table No 22.

PUPILS WHO GAVE THE SAME TYPE OF REASON

FOR FAVOURING MOST A CERTAIN COLOUR AND

FOR RAVOURTHG LEAST ANOTHER COLOUR

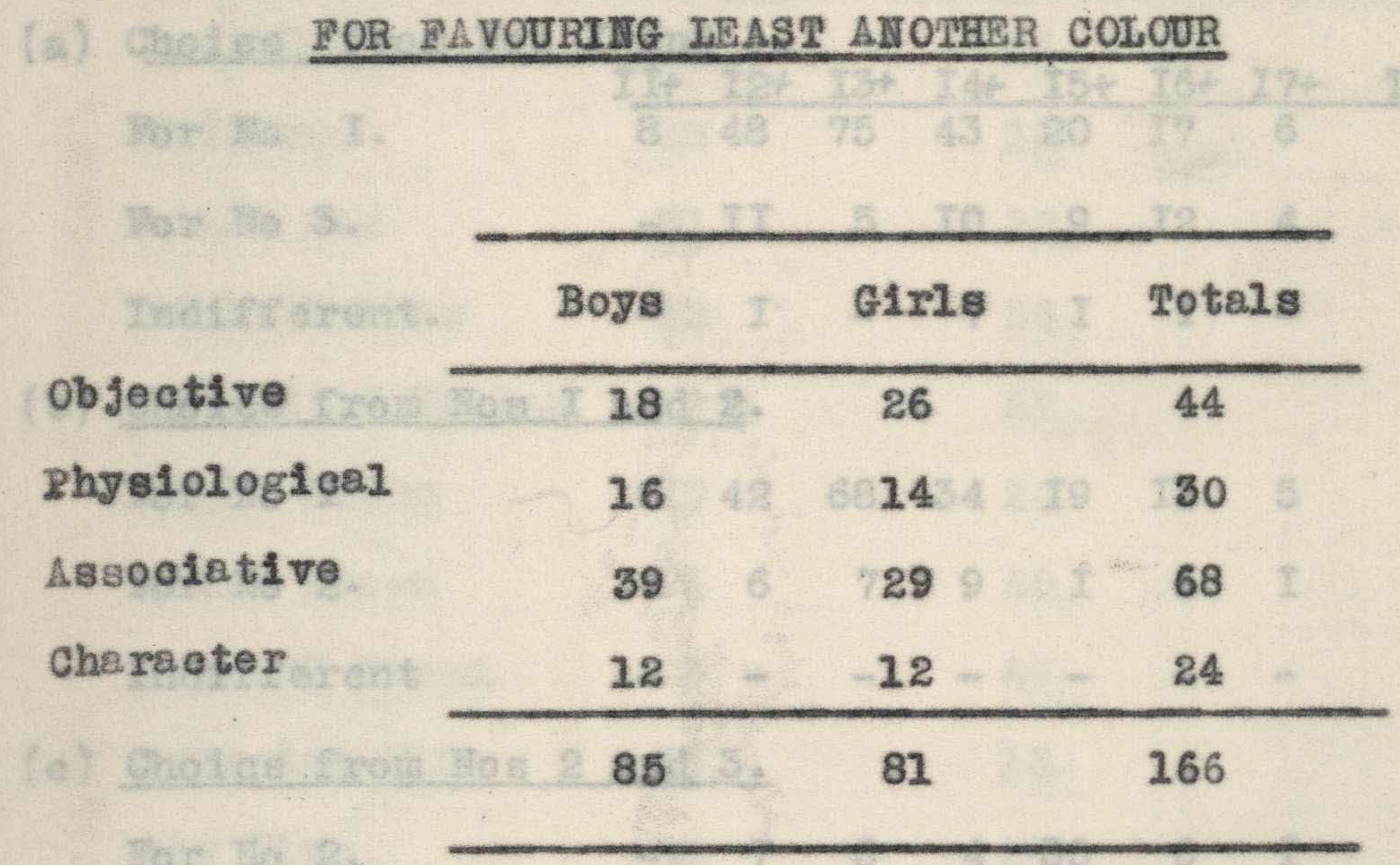

nditiforent.

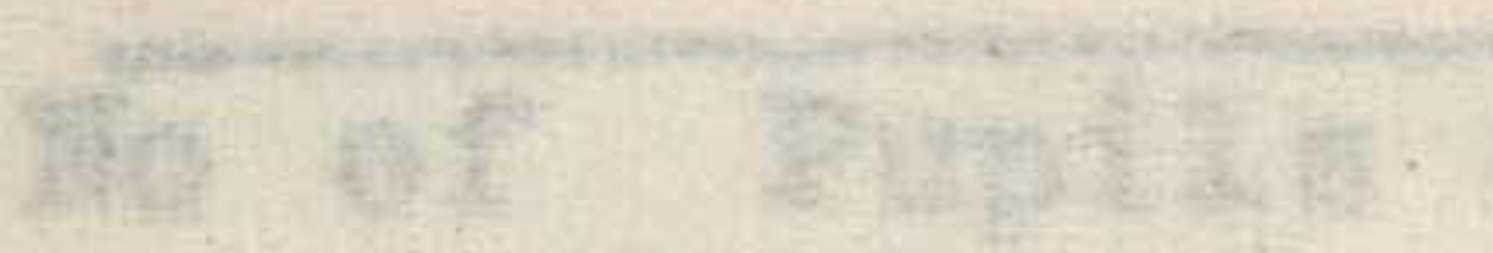

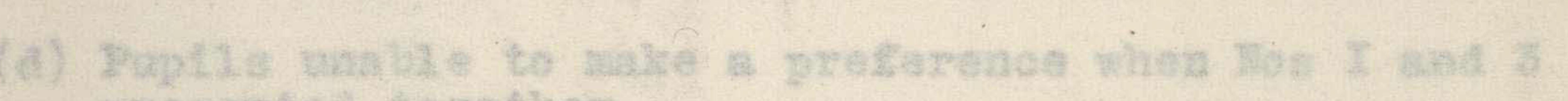

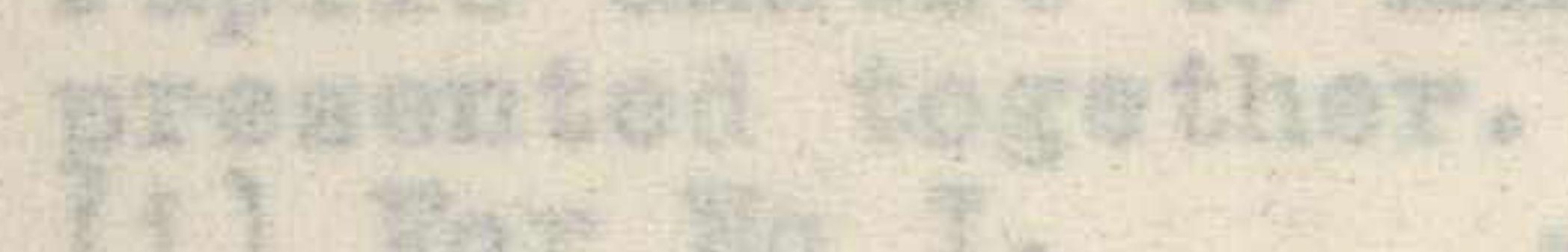

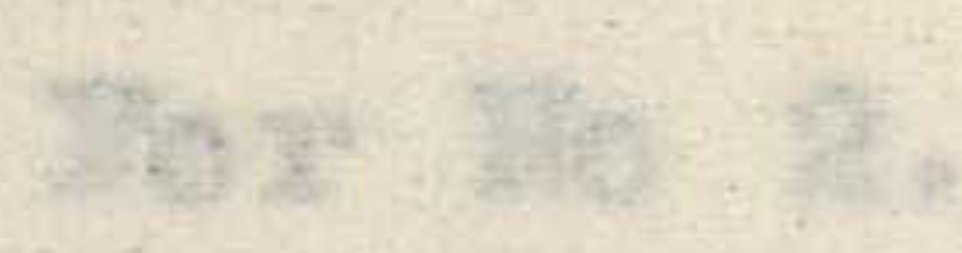

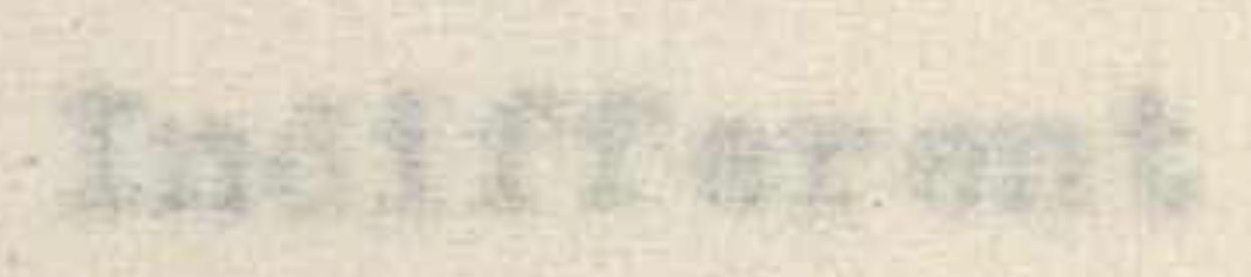

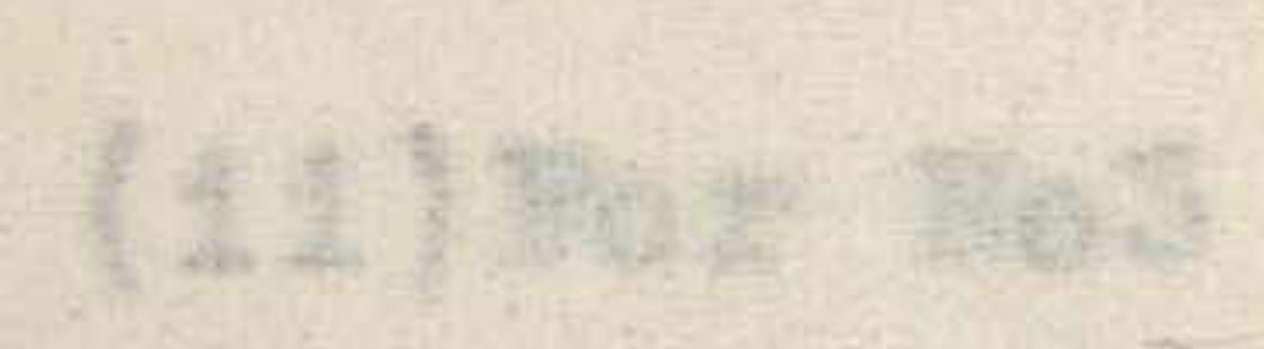

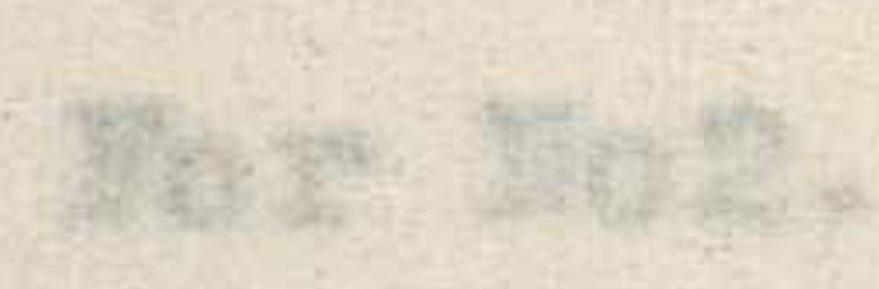

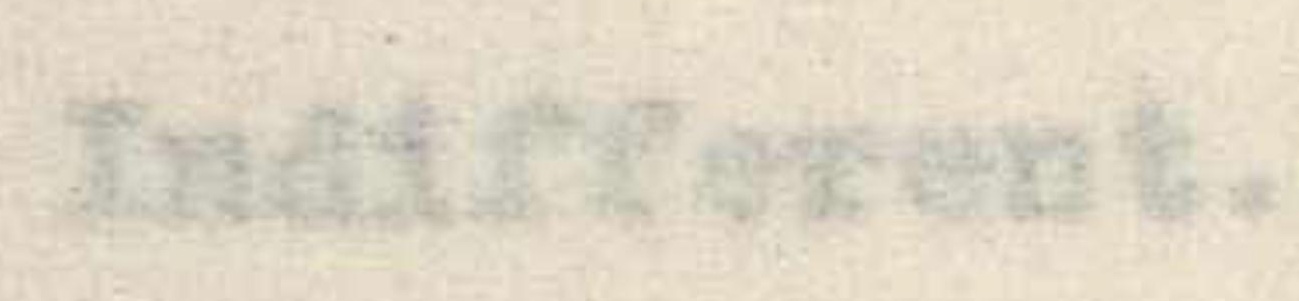


TABLE $N_{0} 23$.

Choice of Pictures.

Picture No I. Raeburn's Mrs Scott Moncrieff".

No 2. Botticelli's "Madonna and Child" (The Louvre, Par No 3. Chantron's "Souvenir" (uncoloured print).

(a) Choice from Nos I and 3 .

For No I.

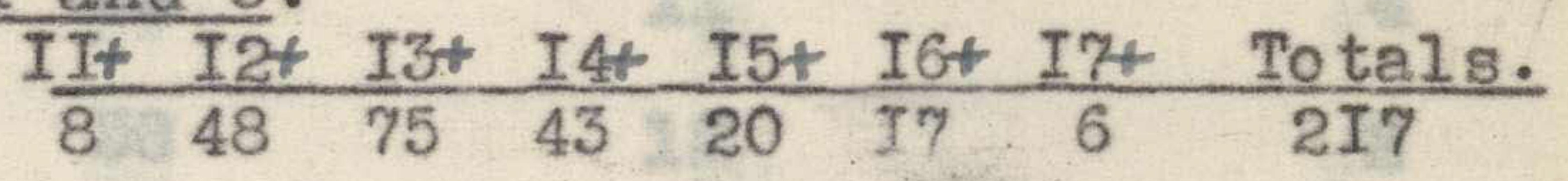

For No 3 .

- II 5 IO 9 II 4 I

Indifferent. $\quad-$ I - 7 II - IO

(b) Choice from Nos I and 2 .

For No I

$\begin{array}{lllllllll}8 & 42 & 68 & 34 & \text { IP } & \text { IR } & 5 & \text { IB }\end{array}$

For No 2.

- 679 I 5 I 29

Indifferent

(c) Choice from Nos 2 and 3.

For No 2 .

For No 3.

$\begin{array}{lllllll}-73 & 735 & \end{array}$

Indifferent.

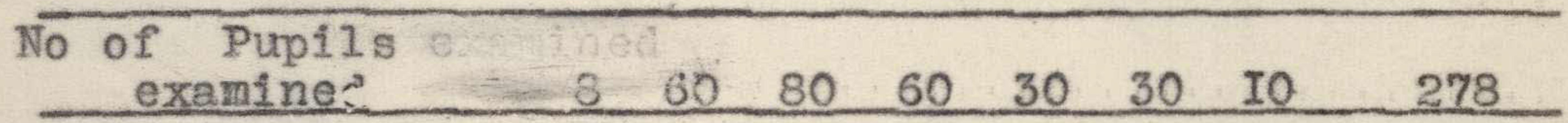

(d) Pupils unable to make a preference when Nos I and 3 presented together.

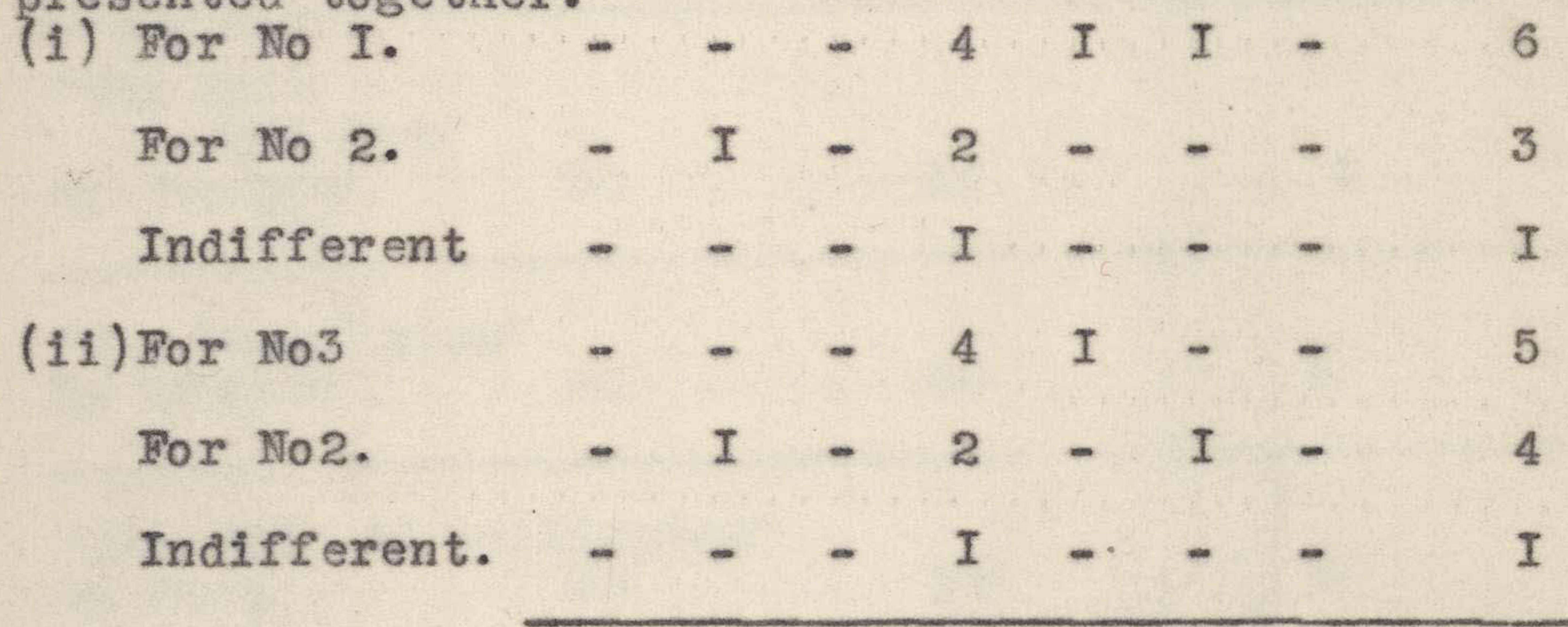


Yable No 24.

INDT VIDUAJ REA CTI ONS TO LARGS AND SYAT工, SOURRSS OF

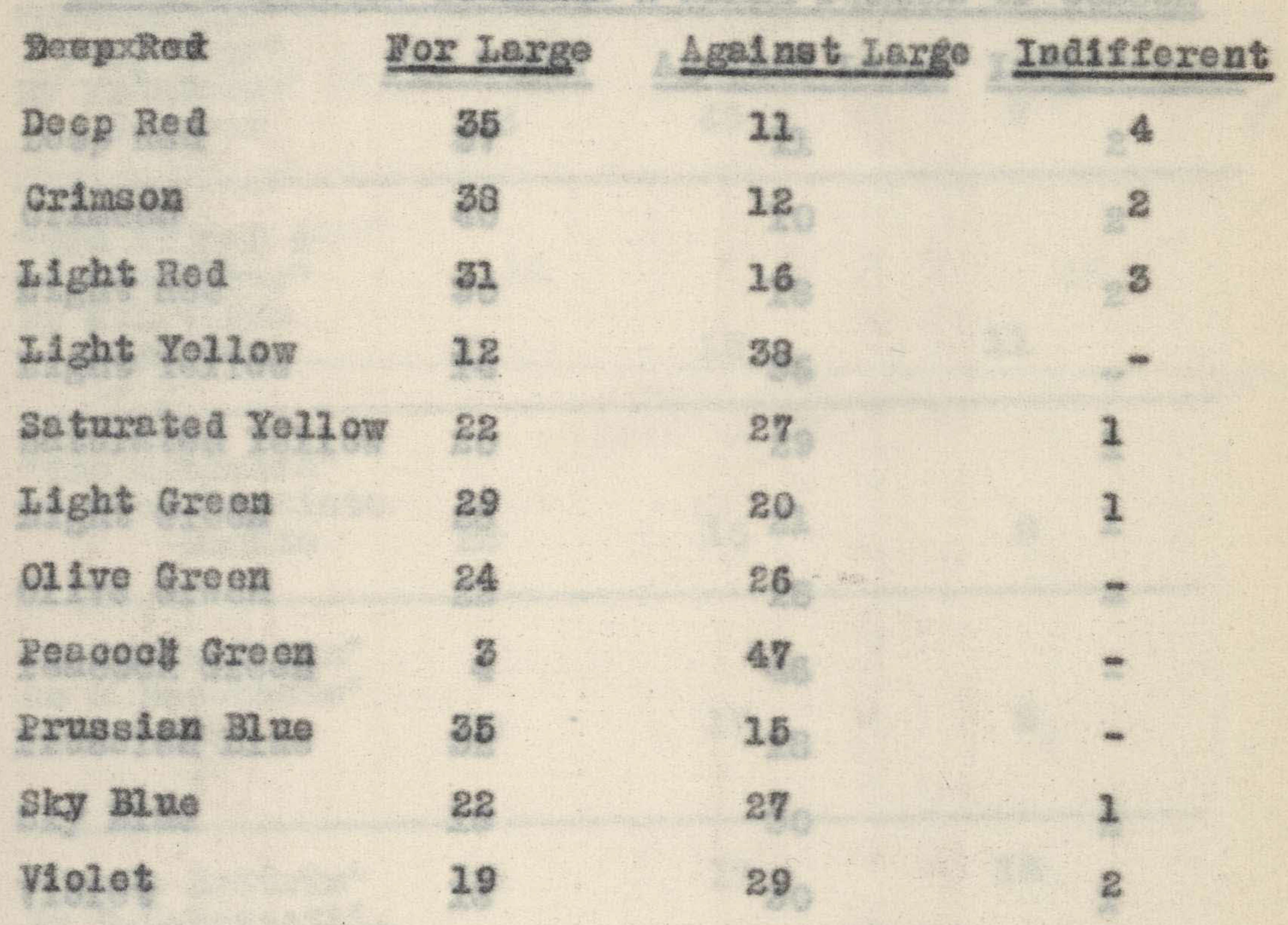

1) 


\section{Yable to 25.}

GROUR PRACRI OMS TO WARES \& SMATL SQUARES OF COLOUR

\begin{tabular}{|c|c|c|c|c|}
\hline 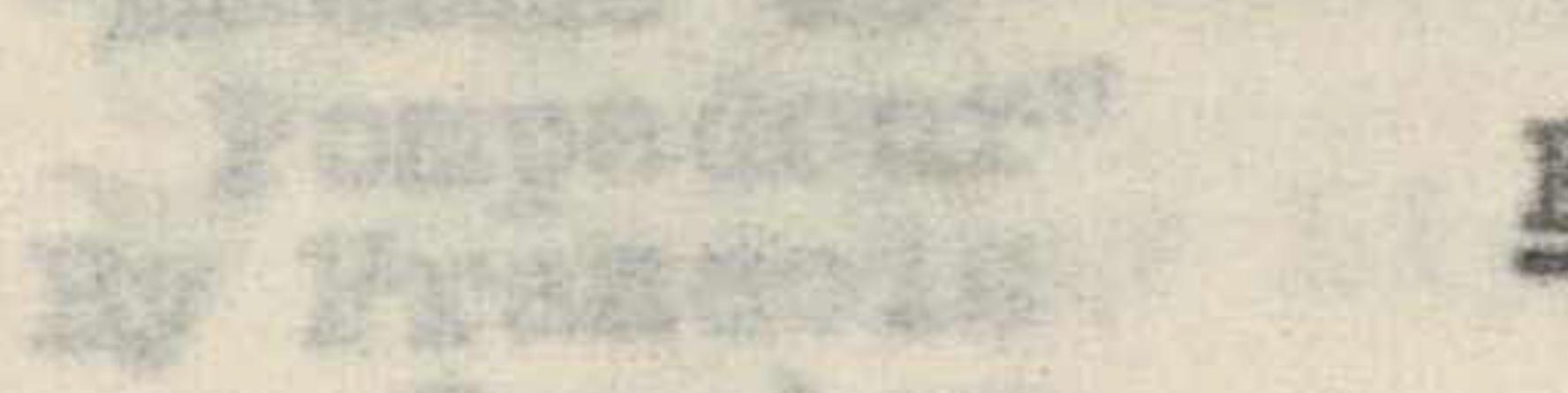 & For IARCE & Against Large & \multicolumn{2}{|c|}{ Indifferent } \\
\hline Deep ped & 37 & 12 & & 2 \\
\hline Crimson & 40 & 10 & & 2 \\
\hline Iight Red & 30 & 18 & & 2 \\
\hline Light Yellow & 34 & 36 & 21. & - \\
\hline Sature tod Yell ov & 20 & 29 & & 1 \\
\hline Iight Green & 28 & 21 & 6 & 1 \\
\hline Olive Green & 22 & 28 & & - \\
\hline Pescock Green & 4 & 46 & & - \\
\hline Pruse1en Blue & 32 & 18 & 2 & \\
\hline Skg Blue & 18 & 30 & & 2 \\
\hline Violet & 18 & 30 & 28 & 1 \\
\hline
\end{tabular}

"contst of a batish

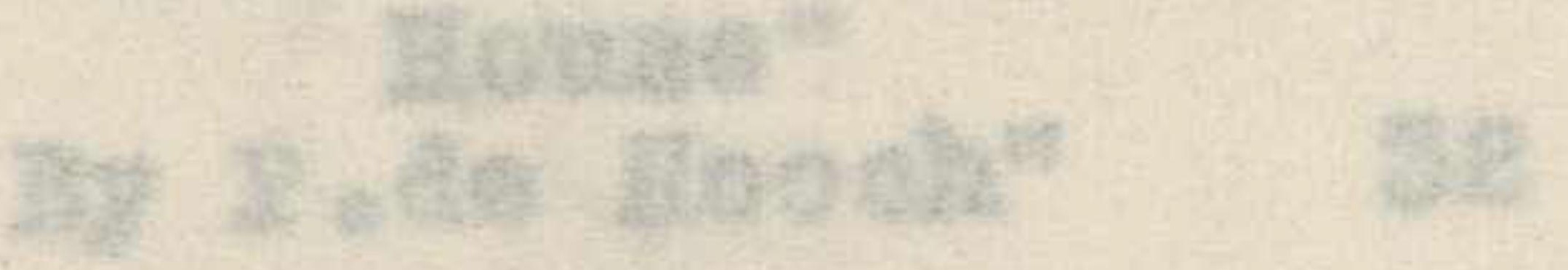

Fighs Bash

By Woalyge

whate Dopost thers:

Hy Meplates.

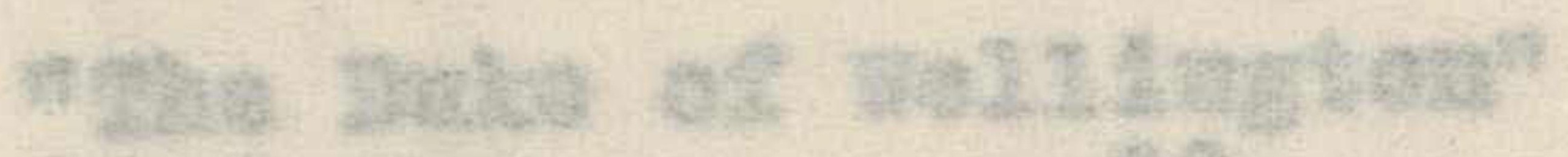

18 coger 


\section{Yable No 26.}

Hame of ploture Bor Jarge por smal1 Indifferent

"Ladame de

Pompa cour"

By Prancole: Boucher

3

40

7

"The Artiet \&

her Daughter"

By B.J.Vigee

Le Brona

21

18

11.

"The $1111 \mathrm{kma1d}$

By Jean-Baptisto Greuze

28

16

6

"Lady Hamsilton"

as a Beochante"

By Romney.

30

17

3

\begin{tabular}{llll}
\hline "Beata Beatrix" & 15 & 17 & 18 \\
By D.G.Rosaett1. & & &
\end{tabular}

"Court of a Dutch

By $\mathrm{P}$. He Hooch"

"The Beilh

Children"

By Vandyko - 30

$18 \quad 2$

"The Deposition"

By Raphael.

2620

4

"The Dulke of wellington"

By Goya.

28

22 
120

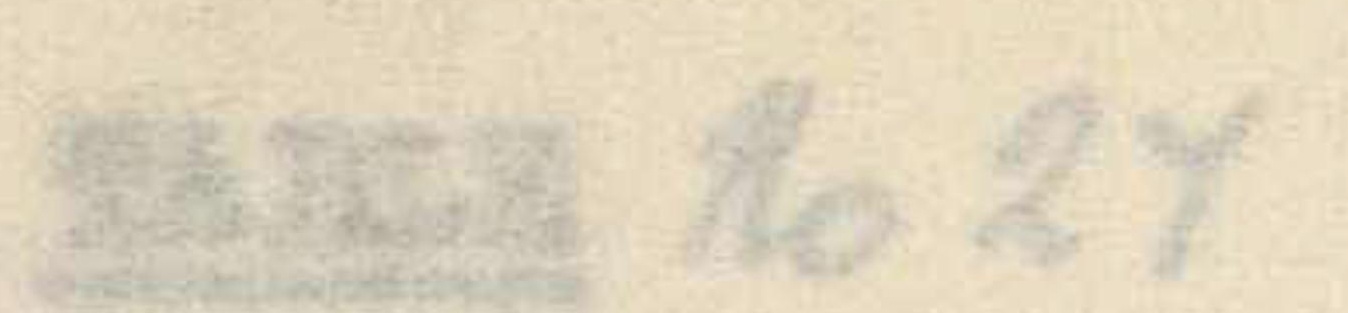

Name of Ploture Ror large For small Indifferent

"Hedonne with the Ch11 d"

By vxe Iippo Iipp1 36

cerd:

12

2

"The Beaver Ilat"

By Rubens.

14

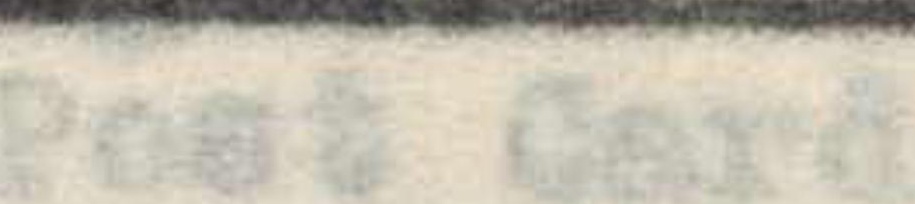

-

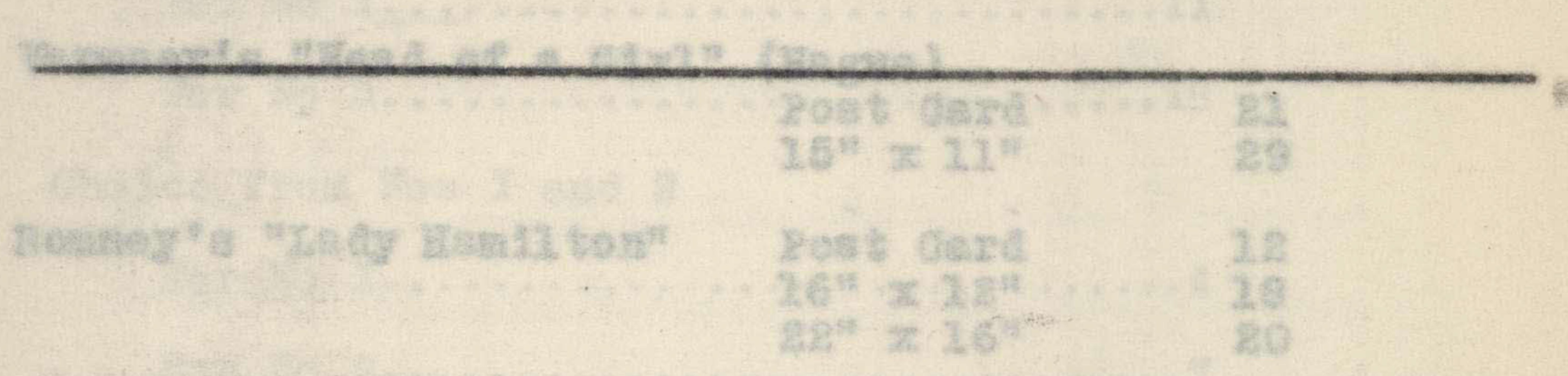

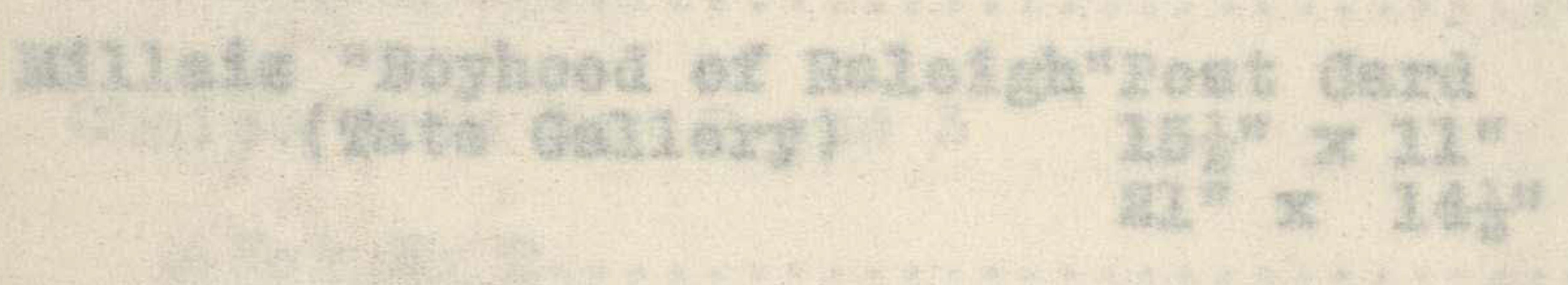

13.

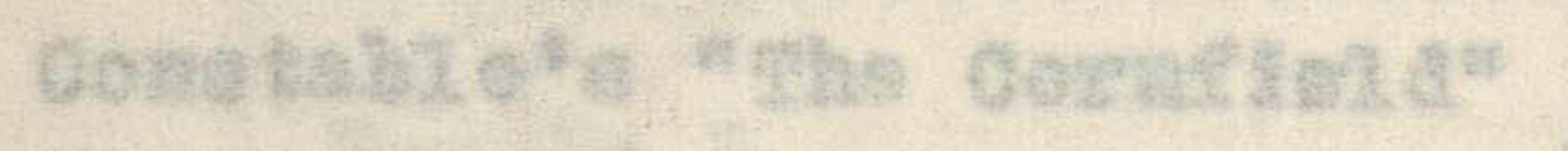

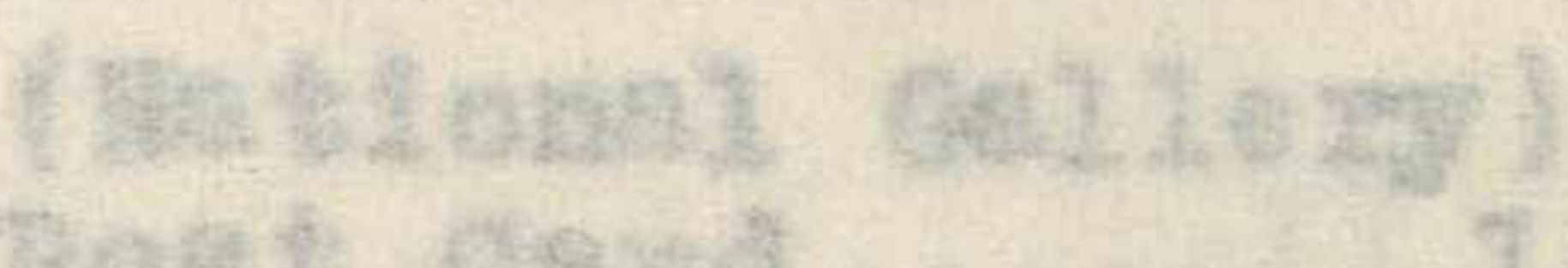

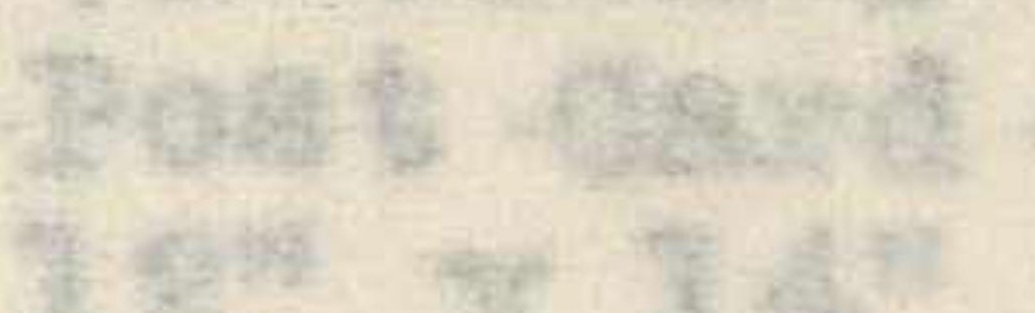

28
29
4
36
26 
TABLI $N_{0} 2 y$

Numbers ohoosing each

Rembrandt's "Young warrior" Post Card) (Glasgow) $g^{n} \times \eta^{n}$ ) havino $28^{\text {n }} \mathbf{x} \cdot 22^{n}$ )

12

23

14

Plo Vermeer's "View of Delft" (Hague)

(a) Chotee fromillos $z$ and 3.

Post card

$12^{n} \times 90^{n}$

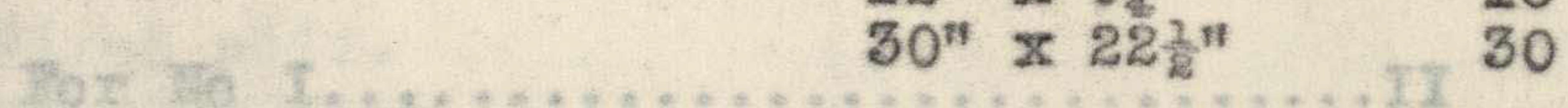

18

Vermeer's "Head of a Gir1" (Hague)

Post derd …18 21

$\begin{array}{lll} & 15^{n} \times 11^{n} & 29 \\ \text { Romney's "Lady Hami1 ton" } & \text { Post Card } & 12\end{array}$

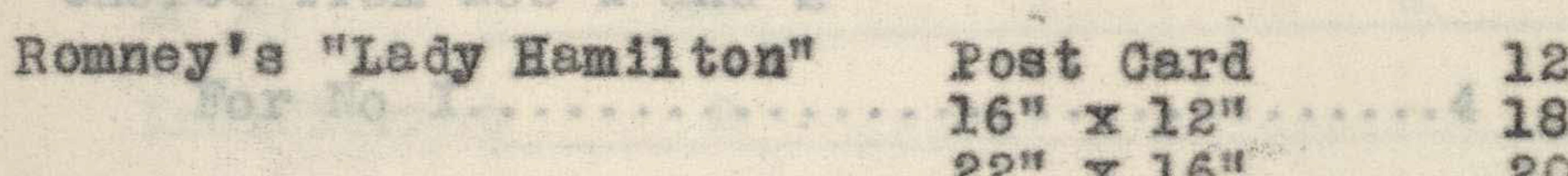

$22^{\prime \prime} \times 16^{\prime \prime} \quad 20$

M11lais "Boyhood of Rale1 gh"Post Card 8

oholo (Tate Gallery) 15i" $\times 11^{\prime \prime} \quad 23$

21" $x$ 14늘 19

Congtable's "The Corneield" (National Gallery) Post Card ..... 14

$12^{\prime \prime} \times 14^{\prime \prime} \quad 36$

Wete: In no case did any chlid hostate es to 
123

122

Choice of TABT, No 28

having children having defective colour vision.

Pictures used: See Table 23.

(a) Choice from Nos I and 3 .

For No $I_{-} \ldots \ldots \ldots \ldots \ldots \ldots \ldots \ldots$ II

For No $3 \ldots \ldots \ldots \ldots \ldots \ldots \ldots \ldots$ Is

(b) Choice from Nos $I$ and 2

For No $1 . \ldots \ldots \ldots \ldots \ldots \ldots \ldots \ldots \ldots$

For No $2 \ldots \ldots \ldots \ldots \ldots \ldots \ldots \ldots \ldots \ldots \ldots \ldots$

(c) Choice from Nos 2 and 3

For No $2 \ldots \ldots \ldots \ldots \ldots \ldots \ldots \ldots \ldots$

For No $3 \ldots \ldots \ldots \ldots \ldots \ldots \ldots \ldots$ II

Note: In no case did any child hesitate as to his preference - there were none" indifferent".

$-0-$ 


\section{Table No 29. \\ Bffects of Constantly Seeing Piotures.

$$
\begin{gathered}
\text { Preference in } \begin{array}{c}
\text { Preferenee in } \\
\text { Pebruary. }
\end{array} \\
\text { Augt. }
\end{gathered}
$$

(a) First pair. for pioture No I. 4 25

\section{Ior pioture}

No 2 . 29 8

Inaifferent 2 $-$

(b) second pair for picture INO 3 T9 23 for pleture Indifferent I4. I0

\section{Plotures used:-}

First pair: I. "Diana of the Uplands".

2 "Phar Jap".

Second pair 3 "Rain, Stean and Speed".

4 "Yachting soene". 
124

$2 \mathrm{D} B \mathrm{~B} \mathrm{NO} 30$

PICTURES REFERRED TO III TABLES 31 and ow Pg 84 .

EXTRA VERT

Picture A: Rubens, "Dana Compestre"

Picture B: Delacroix, "Dante et Virgil"

Picture 6. Signac, "The Harbour of La Rochelle"

INTROVERT

Picture B : Poussin, "Bacchanal"

picture If: David, "Oath of the Horatio"

Picture $G$. Marohand, "The Harbour of La Rochelle: 


\section{A P $P$ B II D I 32}

ONI THE REASOTS ROR FHE GEOTCE OF OCOUPAFIONS AMONG

A PRTMART SCHOOL PUPIIS

Mo.1 - Bovg in stendards in and v1.

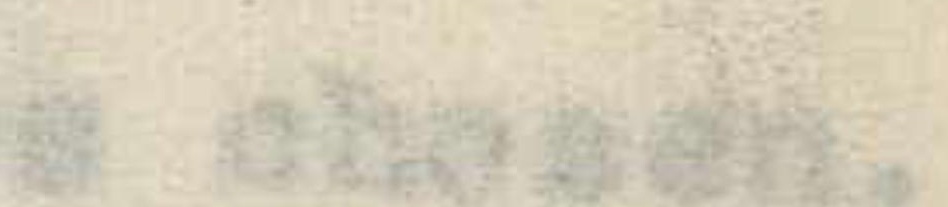

$$
\text { 2A B L B / } 1031 .
$$

Preferencos mede by 100 extraverts - 50 girls and 50 boys, and by 100 1ntroverts -50 glxk \& 50 boys

The plotures. Preferenees for plotures by Preferences for plotures by Irubers Indifforent

presentod extrevert $\$$ artists $\left(1.0 . \mathrm{A} . \mathrm{B} . \mathrm{C}_{0}\right)$ introvert artista $(1.0 . \mathrm{B} . \mathrm{F} \cdot \mathrm{G}$.

toge ther. Istraverts Introverts

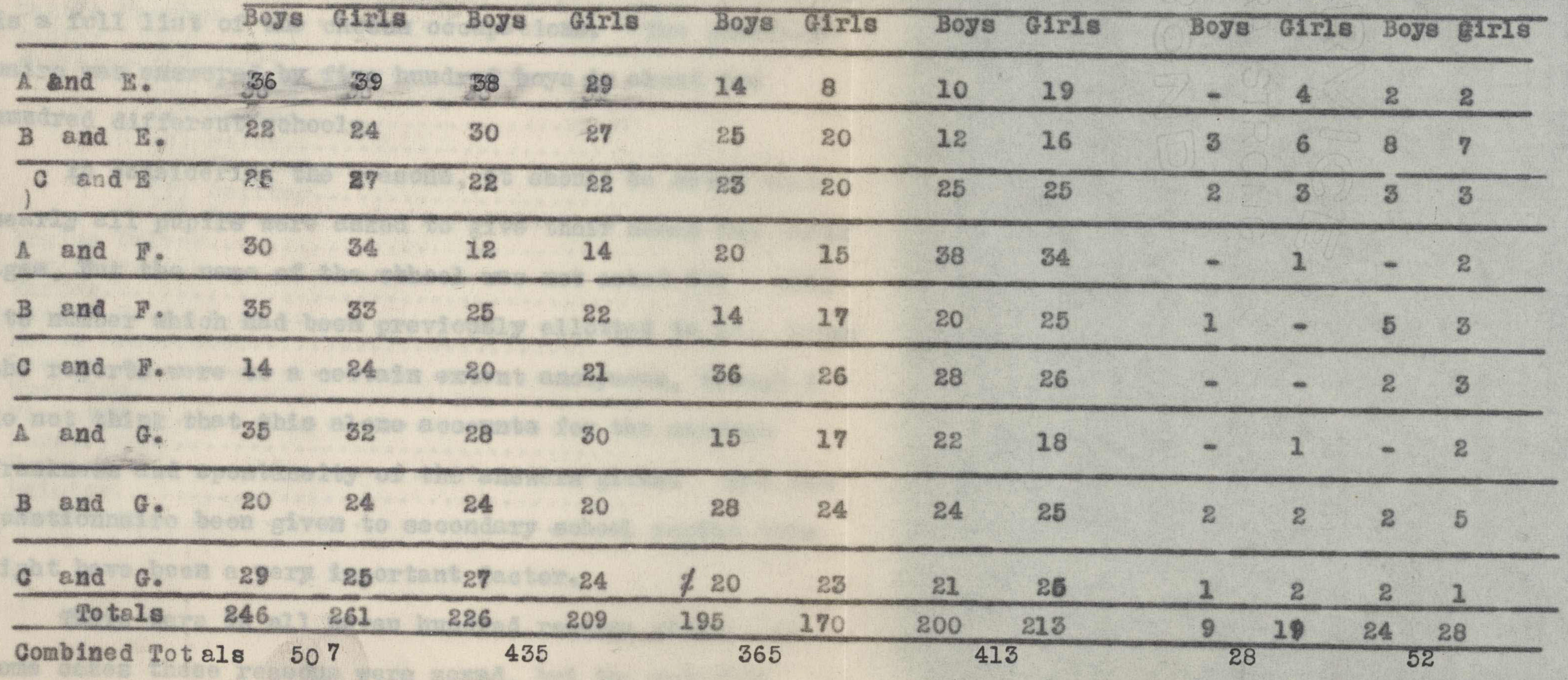




\section{$\Delta B+B$ B I I}

ON THE REASONS DOR FHE GEOICS OF OCOUPAFIONS AMONG

\section{PRIMARY SCHOOL PUPIIS}

Mo.1 - Boys in standards $n$ and $\mathbf{~} 1$.

This 1 s the summary of an article by the writer of this thesis, and is inoluded here as it throws some ilght on the interests of pupils as they enter High school.

Amongst other things, the pupils of Standards $\mathrm{V}$ and VI were ssked to name the trede, profession or calling they would IIke to follow, snd to give as briefly as possible the reagons for their cholce. The following(Pgry) is a full 11 st of the chosen occupations. .. The questionnafre was answered by f1vo hundred boyg in about two huadred different schools.

In considering the reasons, it ghould be noted that nearly a.1 pupils were asked to give tholr names and their ages, Dut the name of the skhool was not asked for - only 1 tg number which had been previoualy allotted to it. Henof the reports were to a certain extent anonymons, though I do not think that this alone acoounts for the extreme Iranknoss and spontanelty of the angwers given. Had the questionnelre been given to secondary sohool pupils this might havo been a very important factor.

There were in all seven hundred ressons given. In some cases these reasons were sound, but the majority 


\section{TABLE No 32 . (Boys)}

Occupation chosen

Agricultural Instructor..................

Aviator............................

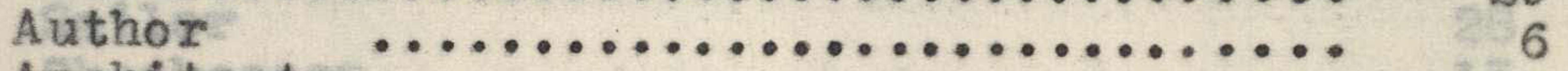

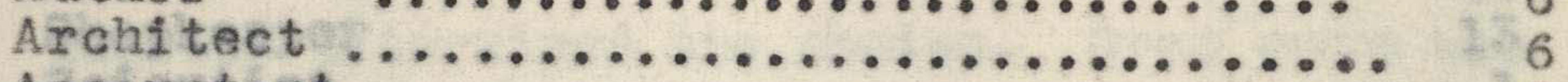

Accountant ............................ 9

Artist $\quad \ldots \ldots \ldots \ldots \ldots \ldots \ldots \ldots \ldots \ldots \ldots \ldots \ldots \ldots \ldots, 1$

Any permanent work $\ldots \ldots \ldots \ldots \ldots \ldots \ldots \ldots \ldots \ldots . . \ldots 1$

Any probession ..................... 2

Bus Driver $\ldots \ldots \ldots \ldots \ldots \ldots \ldots \ldots \ldots \ldots \ldots \ldots \ldots \ldots 2$

Bank Clerk ........................ 3

Butcher $\quad \ldots \ldots \ldots \ldots \ldots \ldots \ldots \ldots \ldots \ldots \ldots \ldots \ldots \ldots \ldots 2$

Bricklayer .........................

Barber $\quad \ldots \ldots \ldots \ldots \ldots \ldots \ldots \ldots \ldots \ldots \ldots \ldots \ldots \ldots \ldots . . \ldots$

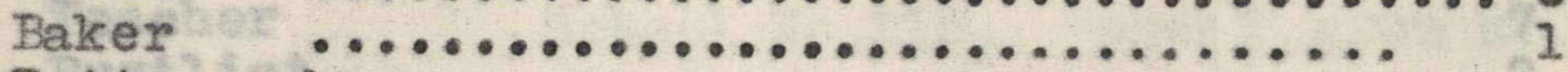

Butter-maker..................... 1

Breeder of Race-korses................. I I

Carpenter ........................ 24

Cabinat llaker ........................ 10

Carrier .........................

Chemist $\quad \ldots \ldots \ldots \ldots \ldots \ldots \ldots \ldots \ldots \ldots \ldots \ldots \ldots \ldots 2_{2}$

Civil Servant ...................... ?

clerk $\ldots \ldots \ldots \ldots \ldots \ldots \ldots \ldots \ldots \ldots \ldots \ldots \ldots \ldots \ldots$ 7

Cricket Coach $\quad \ldots \ldots \ldots \ldots \ldots \ldots \ldots \ldots \ldots \ldots \ldots 1$

Commercial Traveller ................... 1

Cattle Rancher $\ldots \ldots \ldots \ldots \ldots \ldots \ldots \ldots \ldots \ldots \ldots .1$

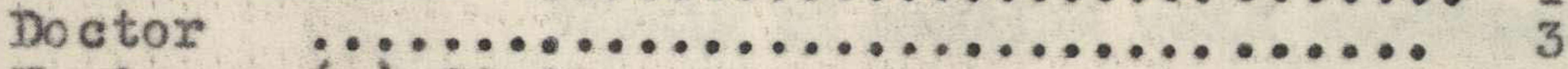

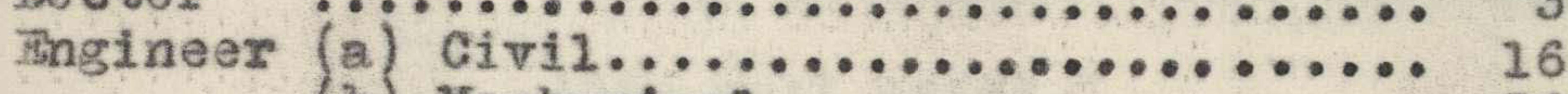

(b) Mechantcal.............. 36

(c) Marine.................... 8

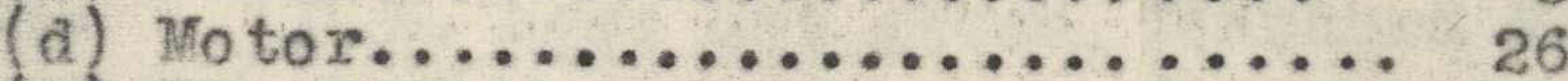

(e) H ectrical............. 2

(f) Railway................ 2

(g) Aeronatical ........... 1

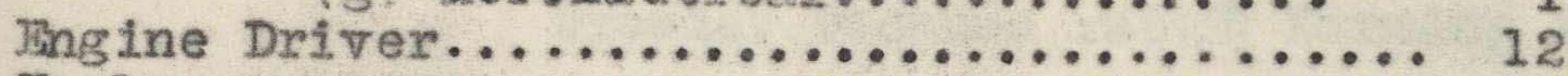

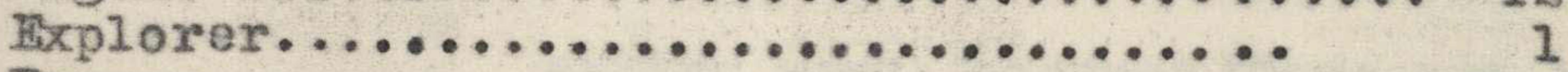

Farreer........................... 148

Facdry Fand........................ 1

Hotel Proprietor.................... 1

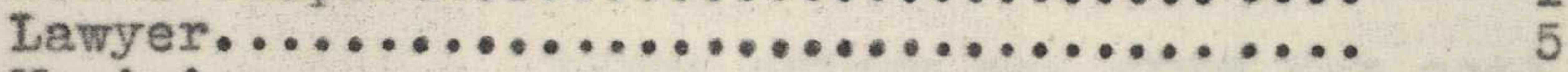

Musicien........................... 3

Minister ............................ 1

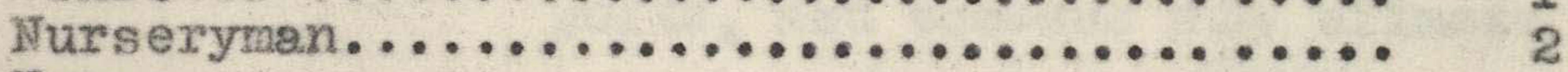

Nurse............................. 1

Painter............................ 1

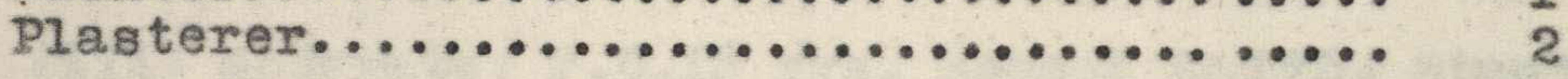


Plumber

Secret Service Agent

Sacdier

Salesman

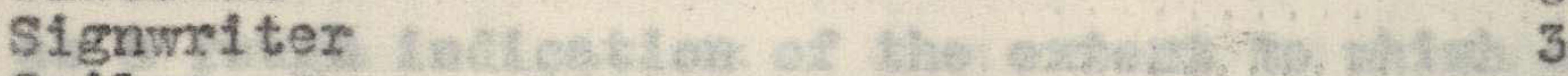

Sallor 28

Shopkeeper $\quad 13$

Scientist $\quad 13$

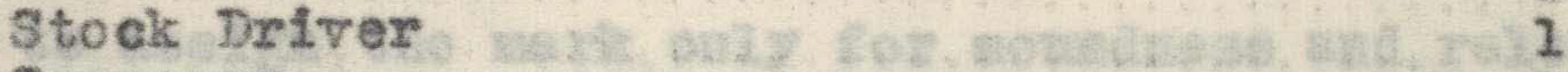

Surveyor 1

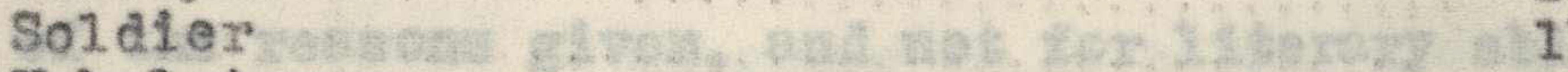

Upholsterer

"Varehouseman

Vireless Operator

1

Watchmeiker

window Dresser

Teacher

Pugilist

ritind not made up

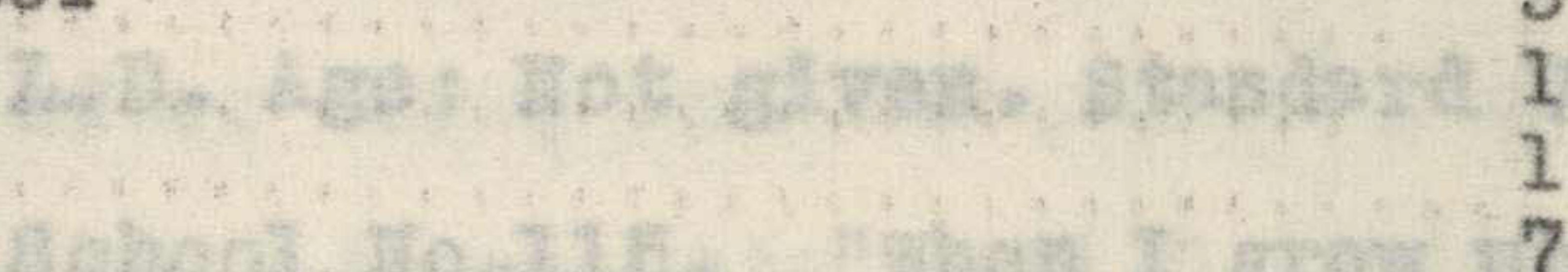

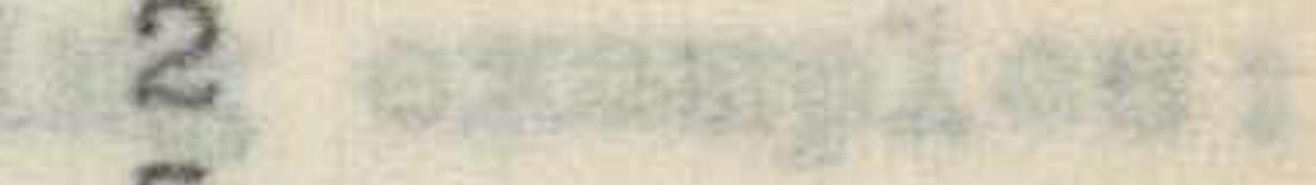

5

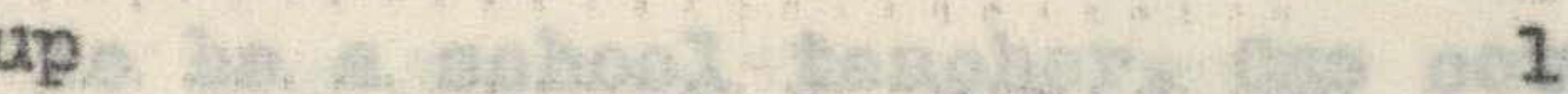

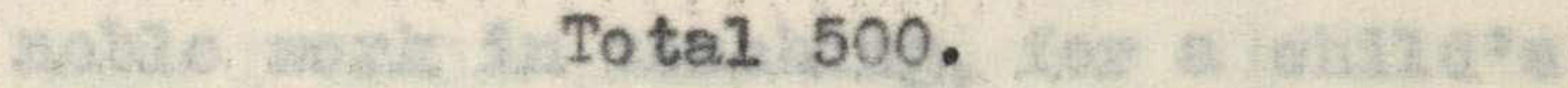

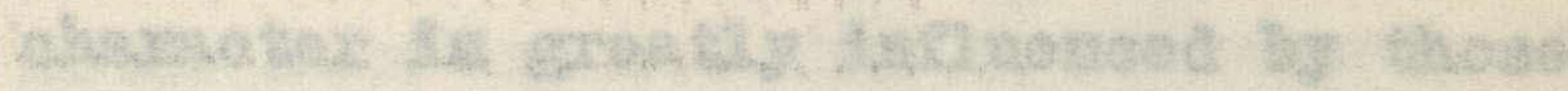

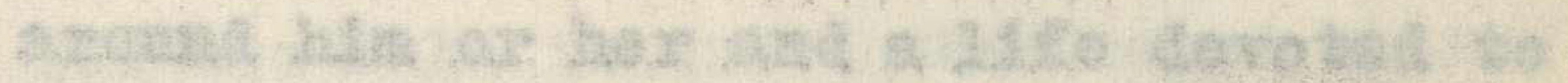

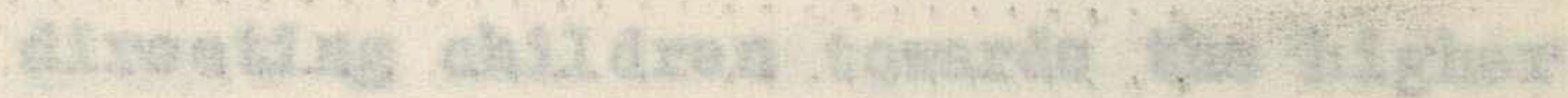

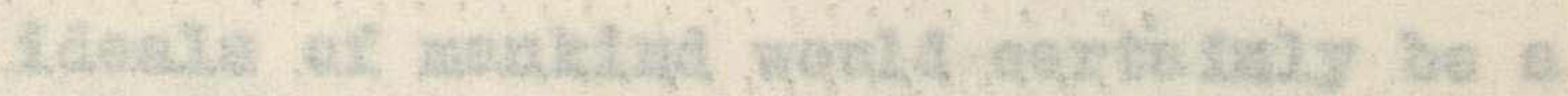

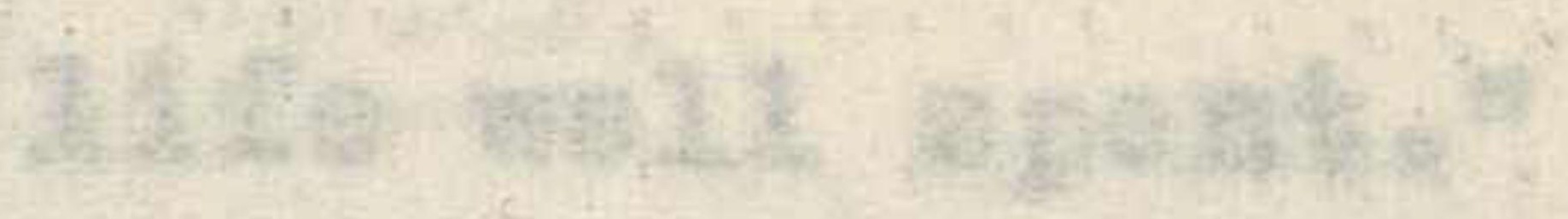

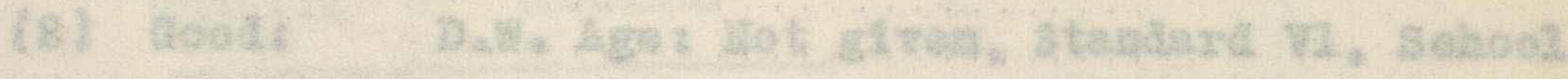

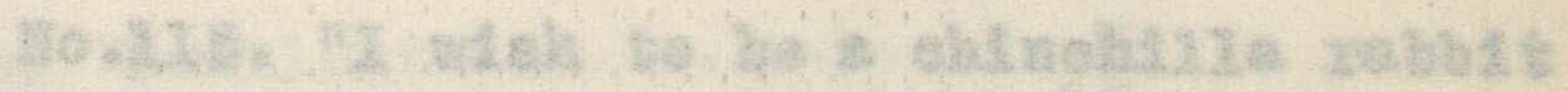

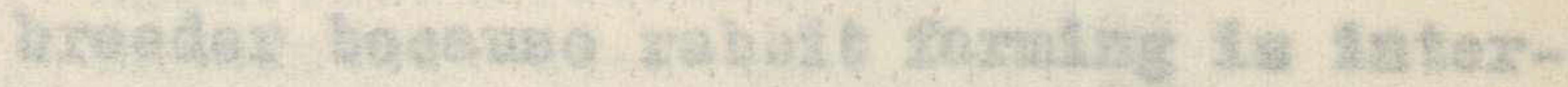

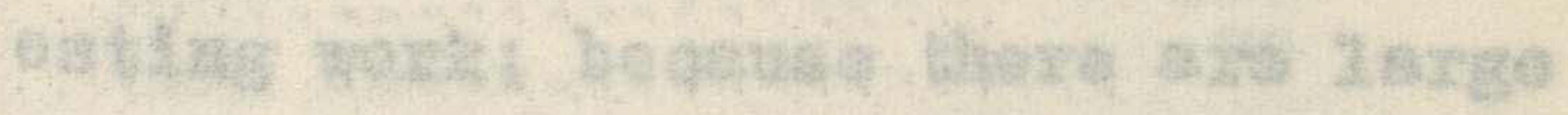

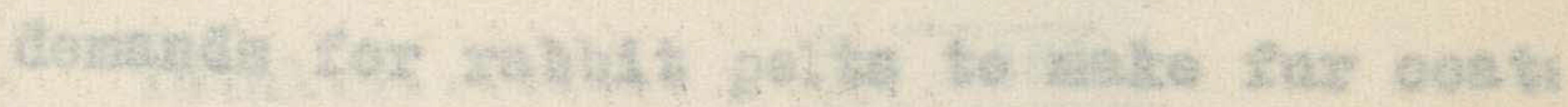

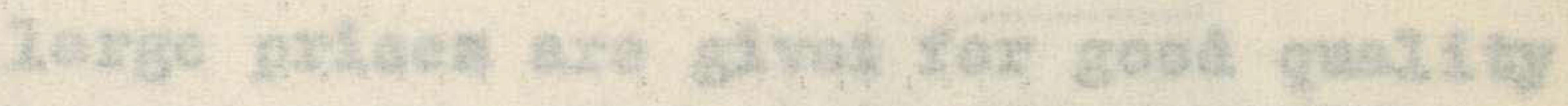

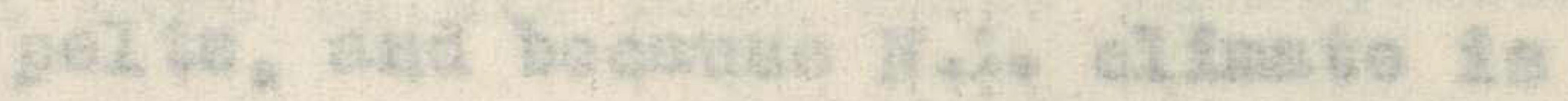

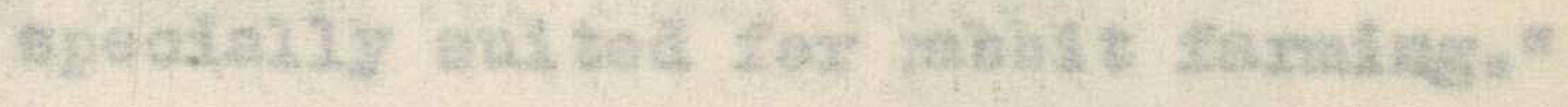

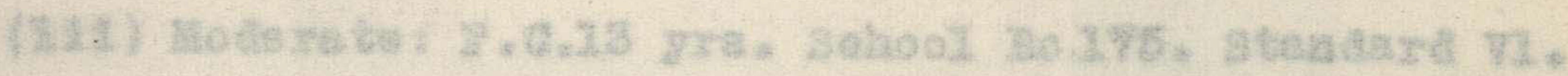

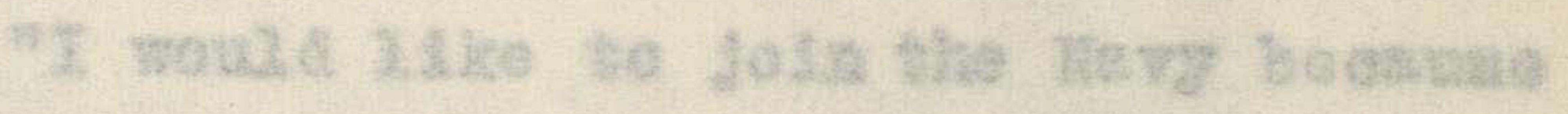

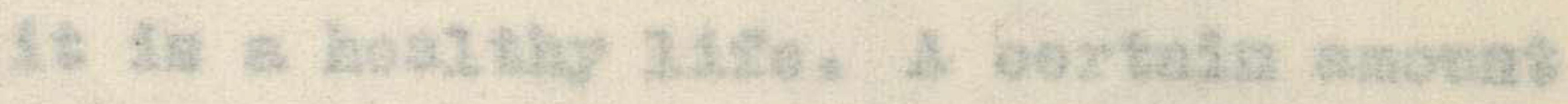


were not, as can be seen by referring to Table 33. A mark was assigned to each boy's paper, as this serves as a rough indication of the extent to whish sound. reasons determined the oholee. Great care was taken to assign the mark only for soundness and relevance of the reasons given, and not for 11 terary ability. The standard aciopted is shown by the following examples: (1) Excellent: I.D. Age: Hot gIven. Standard VIl. Sohool No.115. "When I grow up I intend to be a vohool teacher. one covld do a noble work in teaching, for a child's charactex is greatly influenced by those around him or her and a life devoted to direoting ohilaren towards the higher 1deals of menkind would cortainly be a 11 fo well spent."

(2) Good: D.W. Age: Jot given, Standard V1, School No.115. "I wish to bo a chinchilla rabbit breeder because rabbit farming is interegting work; because there are large demands for rabblt pelts to make fur coats large prices are given for good quality peIts, and because 17.2 . climate is speoiaily sulted for rebbit farming."

(11i) Moderate: $\mathbb{1} \cdot C .13$ yrs. Sohool Bo.175. Standard $\mathrm{V}$. "I would like to join the Navy because it is a healthy 112e. A certain amount 
of money is saved up for you and is made a pension of in later years. It is an education while travelling and makes a man a man."

(iv) Poor: V.D., 12 yrs. Standard V1., School N0.107. "I an going to be a bank clerk because there is plenty of time to have sport after work, and the pay is good."

(v) Very Poor:I.I.,14 yrs. Standard VI. School N0.111. "I wovid like to be a motor mechanic so that I could pril to pleces different motor cars and see whst they are made of. You are abie to drive them round when mended to see if they sre fixed right."

\section{TAमा: No33. QUEATTY OF RTASONS}

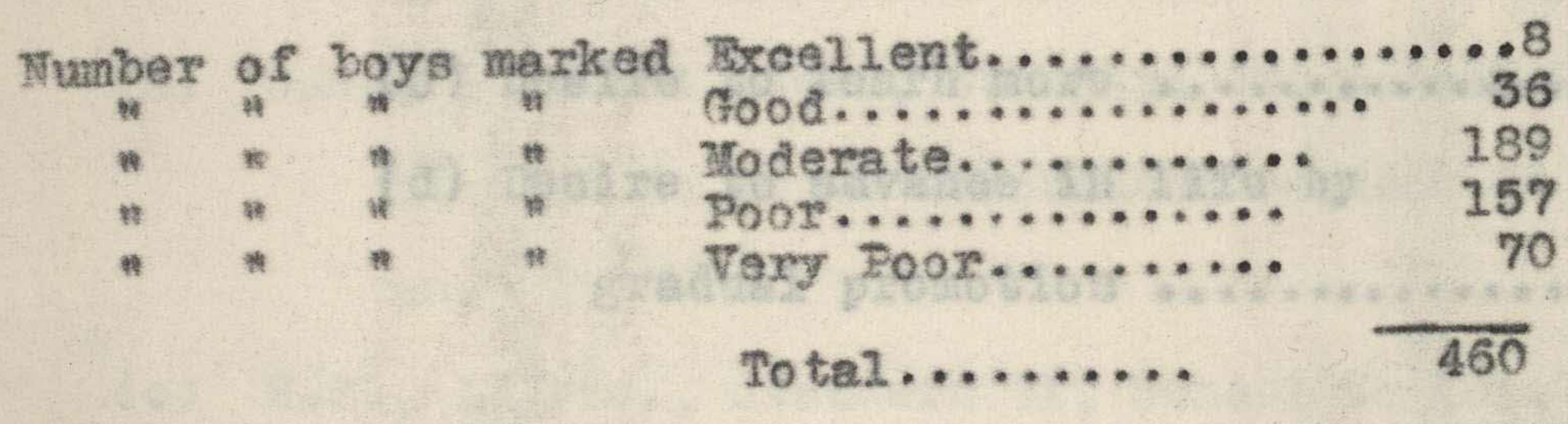

One boy had not made up his mind while thirty-nine boys omitted to give reasons for their choice. 
Onily those papers maxked Good or Excollent have

been regarded as contalning really sound reasons, and so the results show thet $90 \%$ of the boys made their choice on insufficient grounds.

After consideretion of the motives end

reasons in a more detailed way, they were placed into four groups which have been ealled "A", "B", "C" and "D". It should be noted that the totals of these grougs do not colnoide with $7 \mathrm{able}$ 迹 since some pupile gave several ruasons for their ohoice while a few gave no roasons at all.

GROUP "A". These seen to be primary, real or intrinside and they have beon subdivided as follows:-

Reason or Motive. Solnool tho 226, No given.

(a) An interest in the work............186

(b) Ideals $\ldots \ldots \ldots \ldots \ldots \ldots \ldots \ldots \ldots \ldots \ldots \ldots \ldots \ldots \ldots$

(o) Desire to learn more $\ldots \ldots \ldots \ldots \ldots 13$

(d) Desire to advance in life by

gradusl promotion .............. 15

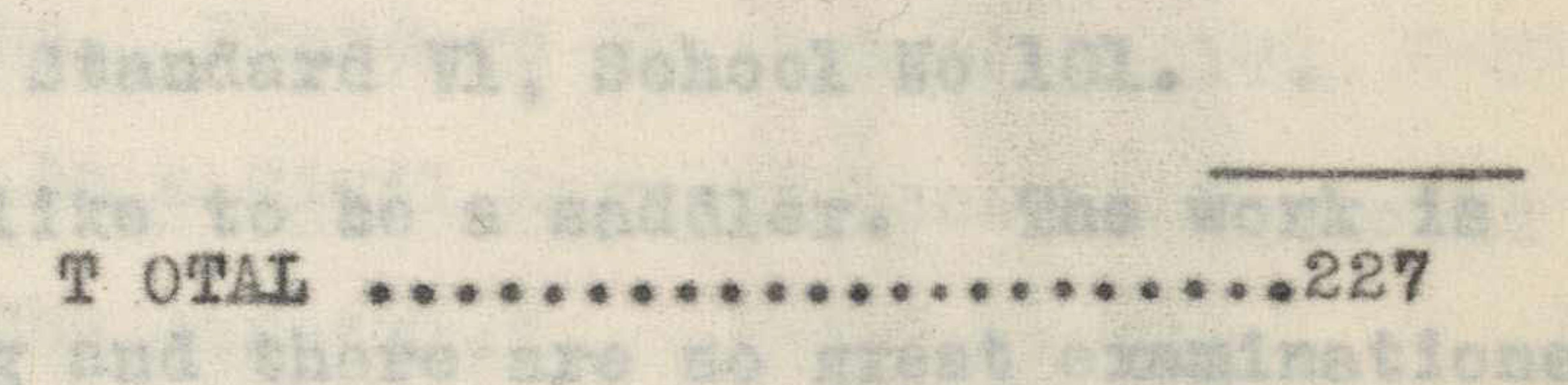

(49.)

One feols rather reluetant to classify into this group reasons such as the following, but this has been done beceuse, when all is said and done common sense tells us 
that before plaoing 1ada in any profession or trade we showld agk first "What do you like, what are you interested in s" If one does not really "1ike" his vecation he becomes a"square peg in a round hole." Nevertheless in considoring these statements one must be very carefol not to jump to conclusions too quiokly, because the experienoe of children of this age is 1 inited and their interests are mainly of a superficial nature. It is quite possible, one feels, that had the questionisire been submitted to this group of boys Immedietely after they had hed a ride gey on a traction-engine, they wovld heve replied thet they wished to be traction-engine drivers for the same reasons as those that follow:-

(a) I.B., 11 yxs.., standerd $\mathrm{V}$, School No 115.

"Hotor mechanje - beoause I like anything concerned with motor cars."

(b) C.H., 13 yre 4 mths., Stendera $V 1$, Sohool wo 164. "I wish to be an accountant because it appeals to me."

(c) W.P., 13 yrs., Standard VI, sohool No 101.1\%? "I should like to be a saddlex. The work is interesting and there are no great examinations."

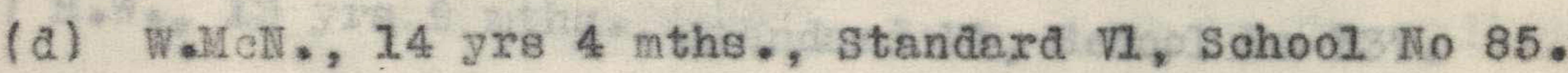
" A sellor, as I have been on a long sea journey before. The sea has been ealling me over since I landed." 
(e) B.R., 14 yrs., Standerd VI, Sehool No 45 .
"A lavger, as I have an inolination to $1 t$, and I like to argue."

Although nearly one third of the total number of ressons offered fall into this group, it will be noted thet the number of staterents of ldeals is only sma11. Exoluaing reasons which oontain statenents such as "I Iike this " or "It Interests ne " the total number of real reasons is only 41 out of 500 or $8.2 \%$ of the totel number offered. It would seon therefore that the boys of this age - from eleven to fourteen years - are still of a proctical turn of wiad, that they are still pragnatiste.

The 1 deal of country is the most popular ideal, as rany be seen in the following:- id lant anses (a) B.S., Age not givon, Standerd $\mathbb{1}_{1}$, Sohool ITo 87 . "I Wish to be a farmer to be a part of the baokbone of our country and help to supply the towng people with food and nake the oultivated area larger."

(b) F. W*, 13 yrs 3 mths., Standard $\mathbf{v}_{\mathbf{1}}$, Sohool wo 17 . "I want to be a Civil Servant because I should be holping the countxy,"

(c) $\mathrm{H.} \cdot \mathrm{W}_{\bullet}, 13$ yrs 9 mths., Btsndard $\mathrm{V}$, School No $13 \%$. " I wish to be a farmer........ when you die you can say you have done your part in the world." 
(d) I.t., 13 yre 11 mths, standaxd $V_{2}$, Sehool Wo 100. " Eaxmex, beeause $\boldsymbol{I}$ ean help the country in whlch I IIve to prosper."

Ideel1stic reasons were mentioned by those who wished to be Englneers (3), olvil Sexvants Pexners (6), Lewyers (1), Sallors (1), Teschers (2). The number indicates, the number of times nentioned in the partioviar oceupation.

The desire to learn more is nentione most often by those who wished to bo ongineers or mechanles, but it 18 aleo mentioned by some who wanted to be famers or esilorg, end by a lad who wished to be a seientist.

The ambition to etert "at the bottom of the laddert and to later advanee in life is in most oases mentioned with increased wages:-

(a) W.H. 14 yrs. \$tandard V1. School Ho.30, "I wovla Ilike to be a grooer bocanse you start as a megsgge boy and work your wey up ant11 you can save enough to start a me11. shop, and al so when working highor up. wages are Inoreased."

(b) B.S. 13 yxs. stendard $\mathrm{V}$. Sohool llo.35. "I should $11 \mathrm{ke}$ to be a elerk in the rallway departuent as there is a good chanoe of getting higher np, a good pay and $\mathrm{s}$ pension whon you are too old to work." walle af fie thines 
GROUP "B". Thirty-three per cent. of the total number of reasons given have been elassifled inte this groug, which containg reasons which would exply to many occupations other than those actually chosen. The motives ere:-

Motive or Reason. No of times mentioned.

To amass money ..........................

To be heal thy ......................... 83

To be certein of steedy employment .......38

To be independent ...................

TOMLI. 229.

of course a really sound cholce might include all these four reasons but each by itself is not a sufficient Justification for undertaking any one trede or profession. K.J. aged 13 years in Standard V1 at Sohool 11017 hes definite ldeag why he should enter the grocery trade:" You can make big profits. If you only have a fer men you wovla not have to pay so much as you don't have a lot to do the same work." From the point of view of making money, ferming seems to be regarded as the occupation (this notive evident 20 times engineering comes second (19 times mentioned), but by the thirteon boys who wish to be shopkeepers money-making is mentioned only four times.

It is pleasing to note tho number of times 
that the desire to be healthy is mentioned. Nearly $50 \%$ of those who wish to be Iarmers mentioned this desire. It is rather emusing to note the horror with which rost country 1ads appear to regard tho "unhealthy towns".

In these deys of economic depression one would expect that the lear of unemployment wovld creep into the reports. The questioneire was answered in November 1929 when unemployment was not such $\%$ problem as it is now - nevertheless the sterdiness of employment 8. a reason for choosing an occupetion is given 38 times in many asferent ways:-

(a) M.R., 13 yrs*, Standard $\mathrm{V}$, School 110175. "I wish to be a brioklayer as it is not over-run 11ke other things."

(b) J.0., 14 yrg 4 mths., Standard V1, Sohool No 169. "Faxmex-Because you can depend on it."

(c) D.R., 13 yrs 4 mths *, Standard V1, School No 1.6. "Teaching, becanse it is a reliable oconpation."

(d) A.B., 16 yrs., Standard v1, Sahool No 30. "I am going to be a tarmer because you are sure of a home. While you are on the public Works Department you are liable to be put off and you have no home. In winter time the bonus is paid out by the iactory which you keop supplying."

As one might expeot, sterdiness of employment is 
mentioned most oftein in reasons for choosing farming (12 times).

The degire for independence is definite enorgh to be singled out as a distinct motive for the cholce of a voeation though it is very similar in some ways to the motive mentioned in the preceding paragraph. It is therefore not surprising to see "independence" thirteen times given as a reason for choosing farming. GRUUY " g". Into this group have been olassified al1 superifial reasons, 4.e. those which are not true reasons but merely statements of incidental sdvantages. The ocoupations have not been chosen for themselves but for something else, and the reasons submitted point definitely to lack of mature judgment. Certainly the motives of Group " $B$ " are open to suspicion but these in Group " $\mathrm{C}^{\text {" are }}$ less compell1ng.

Reegon or Hotive INo of times mentioned.

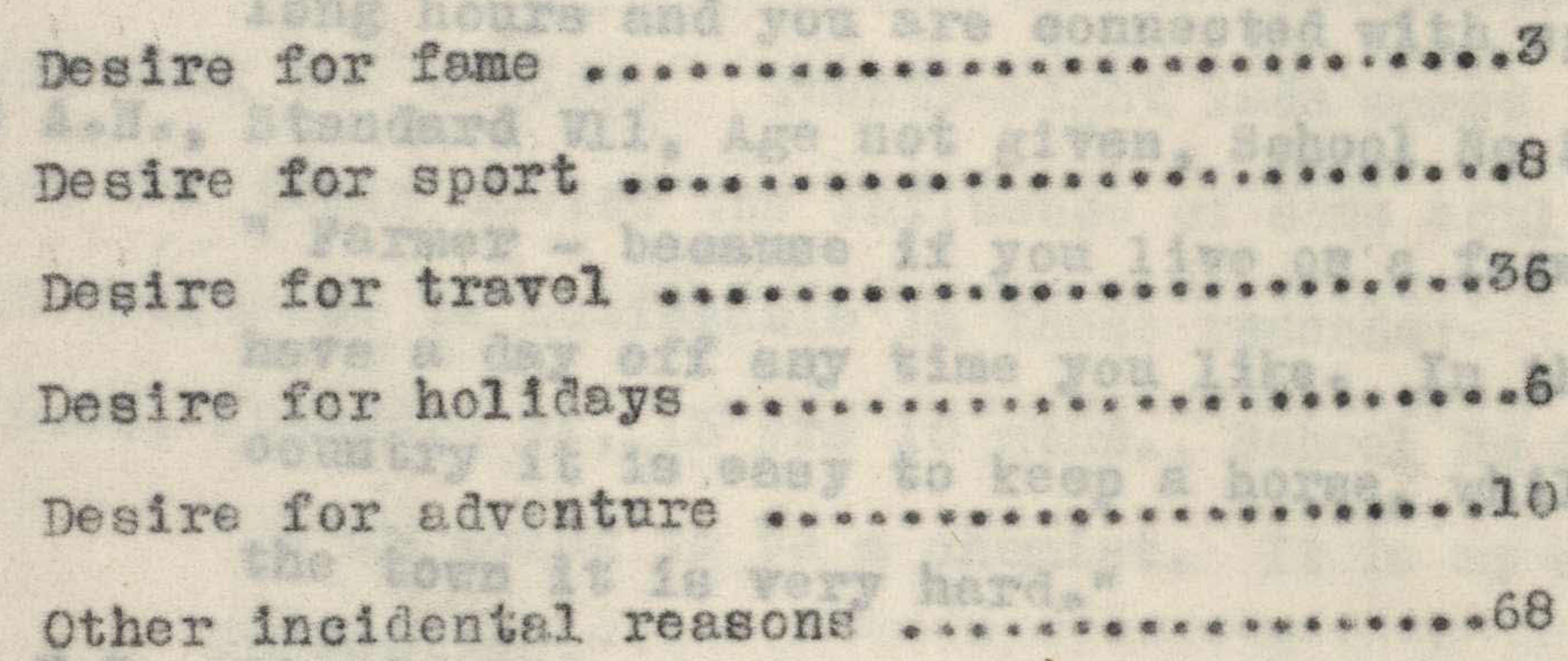

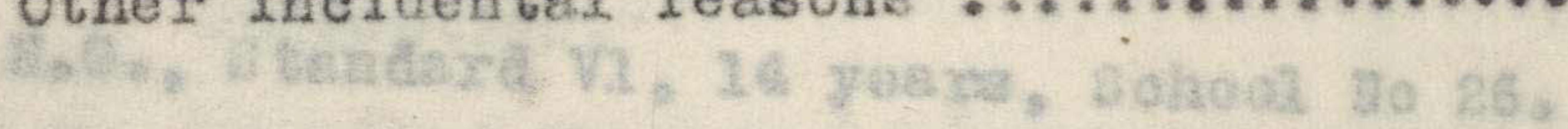

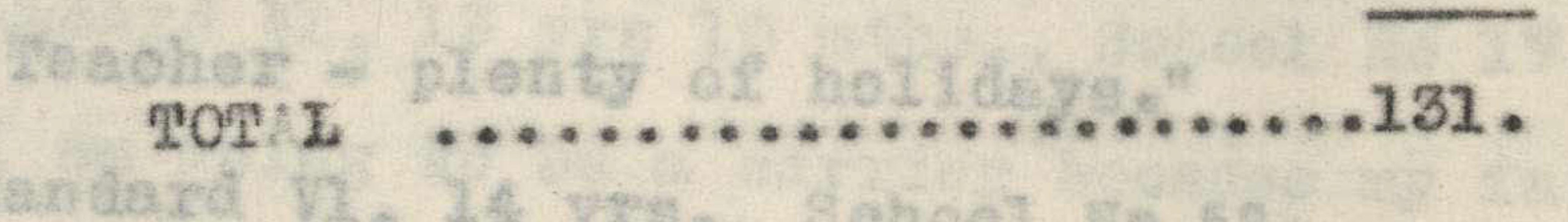


These acoount for $12 \%$ of the total number of reasons given for the oholoe of a particular occupation.

sxamples are:-

(a) G.3., standard $v 1,14$ jrs 1 mth., sohool wo 68 . "I shovla like to be a musician. I have a fondness for music. I wish to win fame and success in my profession as I have a telent for 1 t."

(b) J.MacK., Standard V1, 12 yrs 6 mths,, School Wo 137. "I am going to be a Secret service Agent because I wish to travel and heve adventures." (o) $11 . W .$, standard V1, 14 yrs 1 mth., School No 17. "I am going to be an aviator so as to view the different oountries."

(d) J.D.K., Standard V1, 12 grs 11 mths., School Ho 115. "I am going to be a teacher. There are not long hours and you are connected with sport."

(o) A.N., Standerd VI., Age not given, School No 50. " Farmer - because if you live on a farm you can have a day off any time you 1ike. In the country it is easy to keep a horse, while in the town 1 it is very hard."

(f) N.G., Standard VI, 14 years, Sohool IIo 26. "Teacher - plenty of holidays."

(g) G.II., Standard VI, $14 \mathrm{grs}$, , School tlo 52. "I am going to be a bus driver because it 
is a dry warm job."

It is interesting to read the reasons of

(a) M.D., Standard VI, Age not given, Sohool No 26.

"I am going to be a cricket-coach because you

get sport, Iresh air, and also because I like

the game and would make acquaintances with

famous ericketers."

(b) S.J., Stanđard V1, 14 yrs $5 \mathrm{mths.,} \mathrm{School} 402$.

"I wish to be a pugilist because you can earn plenty of money."

(o) B.J., Standard $\mathrm{V}$, 13 yrs $9 \mathrm{mths.,} \mathrm{School} \mathrm{No} 72$. * I am going to be a breeder of race horges because race horses are most proiltable animals." The motives in (b) end (a) have been clessified into Group $" B^{\prime}$.

GROUP "D". The statements olassifled under this heading are not so much ressons as named outside infinences determining the cholco. Twenty-eight lads named as the reason for their cholce the influenoe of some adult, and adult inflvence is noticeable in these reasons:(a) L.G., Standard V1, 13 yrg 10 mthd., Sohool No 30. "I am golng to be a chemist. It is my motheris suggestion."

(b) S.W., stendard $\mathrm{n}, 13 \mathrm{yrs} 10 \mathrm{mths} .$, School No 17. * I am going to be a carrier because my father is a carrier." 
(c) A.II. standard V. 12 yrs. School I0.17.

"A lawger, because my father is already one and he wishes to have a son in the business, and because I can get a good position there at any time"

(d) R.L. Standard V. 14 jre.8 mths. Tar1k1 Sohool. "A farmer, because when my uncle dies he w111 leave the larm in my name."

It will perhaps be rather surprising to some that adult influence is not more in evidence, but it should be pointed out that Stanley Hall in his book "Youth" says that by the age of twelve the child has adopted "a life of 1 ts own outside the home elrole, and its natural interesta are never so independent of adult InIluence." With the onset of adolescence the child takes a far greater interest in the world of the adult, and as the boys grow older one might expect the numbers Influenced in their cholce by adults to grow. It would be interesting to submit a similar questionneire to secondary school boys for purposes of comparison with an enquiry as to the occupetion of the parents ineluded in the questionnalre.

Thirty-geven boys gave familiarity with the chosen ocoupation as a good and guefiolent reson why they should enter a particular profeseion, trade or celling. (a) A.W. Standard V1, 13 jrs.4 mths. Sohool Ho.29. "I am golng to be a farme $x$, becauge I have been on a farm all my 11fe, and if I went to town 
I wovl a not know anything."

(b) A.S. Standard V1. 12 jrs.11 mths. Sehool I0.35.

"I an going to be a shopkeeper because I am

ecoustomed to the prices and I know the value of an ext1ele."

(e) B.J. Standard V1. 15 yrs. Sohool 110.30.

"I wovla like to be a parson because I have experience in church work. I often holp the minister in st.llery's Churoh with Holy Communion and I heve been promised by one of the ministers to help when I go to the secondery schools "

(a)B.II. Standard V1.15 yrs. sohool wo.182.

"I am golng to be a hotel proprietor because

I have lived in hotels all my 11fe."

The opeupetion in which the familiarity motive is nost evident is laming (20 times mentioned) with earpentering and shopkeeping next in order (see rable In conclusion, I showla like to say a fow observations.

(a) The "respectability" or ant1-manual or oleanliness motive is almost entirely absent.

(b) Lack of mature judgnent is very notioeable. A large number of boys have made a cholce based on mistaken 1deas which seom to Imply' leok of knoviledge, or bsed on trivial or superficial reesons. In view of the faet that so large a number of pup1ls definitely leave school at this age, (The offloial tear Book 
gives 49 () 1 seens that teachors of standards $\mathrm{V}$. and VII might woll spend at least two or three 1 essons a term in discussing with their pypils the qualifications and aptitudes neoesesry for perticuler occupetions. The prospects of regular employment and of advaneement, together with detalls of wages shovla elso be aiscussed. (a) A valuable booklet called "Voeationel Gulance" has been published by the Eduostion Depattment, snd this should prove a great help to teacherg in the preparation of such leseons. Another book well worth purchesing is Loxd wakeriold's "On leaving sohool", published by Hodder \& Stoughton in England at $3 / 6 a$ nett.

(a) The destinetions of boys who left the primary schools 1s shown in the following table taken fron the 11.2 . offloial Yoar Book.

\section{Dostination}

1. Post-primaxy achools 51.

2. Conneroial:

(a) clerioal 1

(b) Shop and werehouse assistent 4 3. Trades:

(a) Engineering.............. I

(b) Buslasing................. 2

(c) other................... 4

4. Farming:.......................... 20

5. Other occupations .................. 7

6. Home $\ldots \ldots \ldots \ldots \ldots \ldots \ldots \ldots \ldots \ldots \ldots \ldots$. 7

7. Mot known 3 
These tegul.ts are based on figures obtained from all the primary schools in the Dominion, and in considering this table with Table 32 one should make due allowance for $10 \mathrm{cal}$ conditions. For instance, it is probable that a far greater proportion of Taranaki pupils when they left school took up farming as a vocation.

(e) This enquiry is by itself incomplete, and should be supplemented by a similar enquiry made in secondary schools preferably in the sane district. A more thorough research woul be valuable from the point of view of fobtaining information which would enable the teacher to gain a more accurate conception of the interests of his pupils, indeed it would also be of use to the parent who wishes to choose a vocation that will be congenial to his child, enabling him to satisfy his natural desire for self-realization, and his degire for happiness through achlevement. 


\section{RTASONS FOR THS CHOTCE OF OCCUPATTONS AIONG PRTIARY SCHOOL PUPTILS.}

No.2. Girls in Standards VI and VIr.

Four hundred and seventy-nine girls in Standards $V I$ and VII answered, the question, What trade, profession or calling would you like to follow? Give as briefly as possible the reasons of your choice" elicited twenty-nine different vocations, and 510 reasons. The callings whic seem to appeal to girls most are dressmaking (116 times mentioned) nursing (67) and teaching (49). Only 20 girls wished to enter domestic service, but the few who did choose this latter vocation gave very positive reasons. Nany married men will agree with $\mathrm{z} . \mathrm{N}$.. Standard VI, in school No.47, who says, "I should like to be a cook, because the main thing in life when a girl marries is to be able to cook her husband a good meal". Thirty-four girls made a choice but did not give their reasons, and twenty-seven girls said that they had not made up their minds.

Adopting the standard 1llustrated in my summary of the boys' reasons. I assigned a mark to each glrl's papwe to serve as a rough indication of the extent to which sound reasons determined the choice. The quality of the reasons submitted is as follows: Trcellent, 12; good,45; moderate 104; poor 93; very poor, 64. It w111 be seen that the number of sound reasons given by the girls is slightly higher than the number given by the boys 
(about 7 per cent) but it cannot be overlooked that about 83 per cent of the reasons were inadequate. As was the case with the boys' sumnary, the motives and reasons were placed in four groups, which were called A.B.C. and D.

60 to Group A- These seem to be primary, real, or intrinsic reasons, and have been subdivided as follows: (a) An interest in the work. 229; (b) desire to advance in 11fe by gradual promotion, 4 ; (c) 1deels, 26;

(d) desire to 1 earn more, 11: Total, 270.

Al though the number of statements of 1 deals is small it is twice as high as the number made by the boys. On the other hand the number of real reasons (excluding such statements as"I $11 \mathrm{ke}$ this" or "That appeals to me") is much smaller. With the boys the most popular Ideal was the 1deal of country: with the girls the ideal of helping others is the most prominent_ Ispecially was this mentioned by those who wished to be nurses (a) I.B., fourteen years, Standard VI, School No.104: "I would Iike to be a nurse so that I uld save people much suffering"

(b) A.H.age not given. Standard VII, school No.115; Nurse, because it is a noble work to take care of the sick and wenting people." J.B., aged thirteen years, in Standard VI at school. No.35 wished to be a missionary "To teach the natives to Iove the real God". Idealistic reasons 
were mentioned by those who wished to be doctors (2) domestics (2) girl guide leader (1), missionaries (2) nurses (17) and teachers (8)

The desire to 1 earn more is mentioned most often by those who wished to be nurses or teachers, but girls do not seem to be so ambitious as boys to start at the "bottom of the ladder" and advance later in 11fe. For Instance, thirty-five girls wished to enter offices, but this ideal is mentioned only twice in this connection Group B.- About 15 per cent. of the total number of reasons have been classified into this group, which contains reasons which would apply to many occupations other than those actually chosen. The motives are: To amass money, 31 ; to be healthy, 28 ; to be stready certain of steady employment, 5 ; to be independent, 11; total 75 times mentioned.

Money-making is mentioned most often by those who wished to be office girls or teachers_ A full purse. however, does not seem to worry children very much. They do not seem to regard shop-keeping as being a trade to enter in order to make money. Serving goods and meeting people seems to appeal more. I.A. age not given, Standard n In school No.72, says, I should like to serve in a shop because you are not 1onely, and you can make many friends."

The desire to be healthy is not so evident in the girls' answers as in the boys'; steadiness of employment 
does not appear to worry them. The desire to independent, however, though mentioned only a few times, is very definite - (a) G.T. twelve years, Standard VI. school No.157: Nurse. You do not have to sponge on mother and father." (b) c.ll. fifteen years, Standard VI, school 149: "Typist, because you are at your own risk if anything goes wrong, and nobody else has to interfere with you except your managers."

$$
\text { Group C.- Nearly one-third (139) of the total }
$$
number of reasons offered falls in this group, wich contains trivial reasons or mention of side issues. The ease of getting a job does not weigh heavily with the girls (only five times mentioned), but this does not an that the girls are less tempted than the boys to take up "blind alley" occupations. Actually there are fewer occupations open for girls (29 mentioned by the gIxls, 63 by the boys). It seems, too, that even at this tender age a few girls unconsciously recognise or desire to provide for the possibility of marriage. Statements that the experience and knowledge gal ned in a particular occupation might be useful "later on" is mentioned no less than fourty-four times (dressmaker 33 domestic 3, nurse 8) - e.g. K.I.C., fourteen years, Standard VI, school No. 17: "I wish to be a dresmaker, because it will be useful in a home." Short hours and holidays are desired by eight girls who wished to be 
teachers or office girls. The "respectability" or cleanliness or anti-manual motive is not very evidentit was mentioned in the girls' reports eleven times, in the boys' papers only once- (a) D.P. thirteen years, standard VI, school No.16: "I am going to be a musician as music takes one more into society".

(b) J.V., fifteen years, Standard VI, school No.183: "Dressmaker because it is not dirty, and you meet nice girls there." There were many other trivial reasons given, such as easiness of the work (15). opportunities for sport (3) travel (7). Bight girls chose farming "because of the pets and the cheapness of milk, butter and eggs", and nine girls wished to be dressmakers so that they might "keep up with the fashions" and have cheaper dresses. Group D.- The statements classifled under this heading axe not so much reasons as named outside influences determining the cholce. While adults do not seem to have directly influenced very much either the boys or the girls, the number of boys (28) who made reference to the opinions, suggestions, or advice of adults was more than double the quantity of girls (12). The numbers are, however, too small to enable any safe conclusion to be derived therefron.

only fourteen girls as compared with thirty-seven boys gave familiarity with the chosen occupetion as a good and sufficient reason why they should enter a 
particular profession, trade or calling. Bxamples(a) F.J.. age not given, Standard VI, school No.65 "Housework, as I have been used to it practically all my life". (b) I.V. age not given, standard $\mathrm{V}$, school No.147: "Journalist, because my essay work comes rather easily. It will be very good to write books like Shakespeare and Bdith Howes." The famillarity motive is most often mentioned by those who wished to be farm girls, music-teachers, dressmakers, or domestics.

Not one girl expressed the wish to be a boy. al though M.D. f fourteen years, Standard VI, school No_43 did say that she wanted to be an engine-driver because she "liked all mechanical works and steam-works". In the Forum of Bducation* for February, 1930, is an account of an enquiry made by $\mathbb{F} . \mathbb{N}$. Richle, M.Sc., lecturer in Fducation at the University of Birmingham, as to the reasons for the choice of occupations among seondary school girls. About 3 per cent of the girls here expressed a desire to be like boys or to pursue boys' occupations. The destinations of girls who left the primary schools is show in the New Zealand official Year-book," as followsi- (I) Post primary, 51; Commerclal- (a) Clerical, 1; (b) shop and warehouse assistants, 3; (3) trades, 1; (4) farming 1; (5) other occupations, 6; (6) Home, $34 ;(7)$ not known, 30 to tal 100 per cent. 


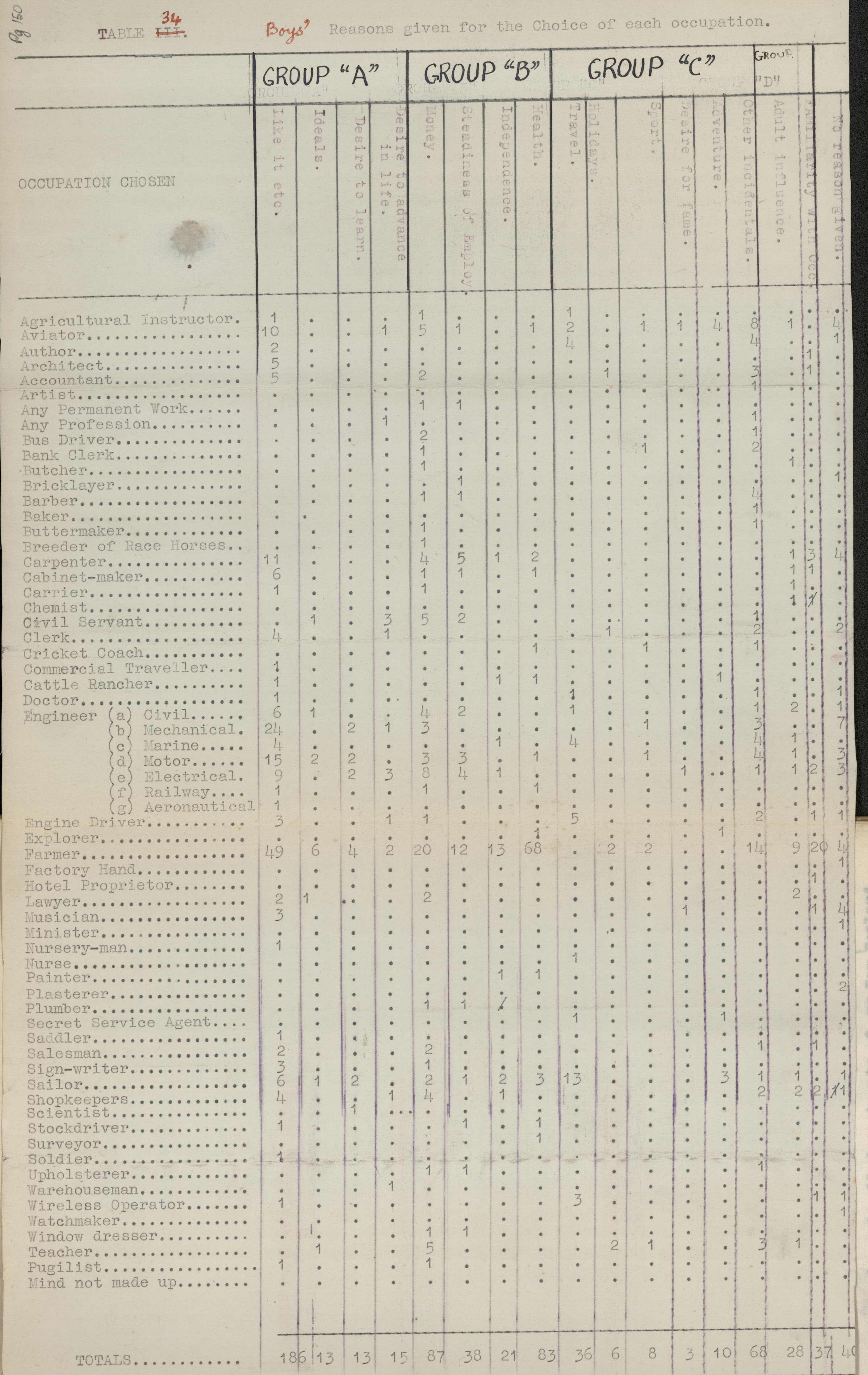




\section{ABXENDTX NO TNO.}

\section{The Two Poyohologicel Types in Roetry.}

An interesting comparison betwoen the reactions of extreverts end introverts to poetry by extrevert and intravert poets may be made by reserring to Tables $\mathrm{J}$ and $\mathrm{K}$, at the end.

Applying the prineiples deseribed in 8 previous section of this thesis to poets and pootry it is readily seen that the two types do exist. One may make the aivision on many lines, but the resvits are not very different. One the one side there is revolution, on the other acceptance; on the one Ireedom and wilfulness, on the other art and labour and learning; on the one conservetism, tredition, sobriety, the quie tness and confidence of anclent ways in thought and form and language, on the other the pleasures and dangers of originality and novelty, the confidence of youth, impatient at the lethargy of euston, eager to make all things new, and sure that making them now is the gome thing as making them better.

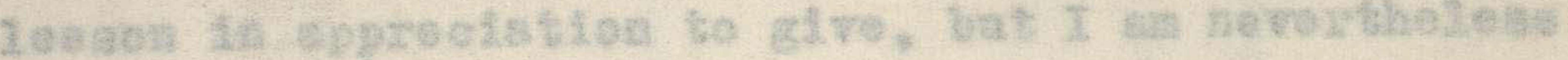


The tables are self explanatory. It w11l be seen that in general there is a small but definite tendency for poetry by extraverts to appeal more to extravert children and for poetry by introverts to appeal more to children of the same temperament. This seems to therefore reinforce one of the conclusions made in this thesis: that the works of each type are more 1ikely to appeal to children of the same type. The tendeney is more clearl $\mathrm{y}$. to be seen in the case of the girls than in the case of the boys. I do not,however, wish to imply that children are specialized in their tastes, for it is clear that they are not by any means so. It is just as $11 \mathrm{kely}$ that poetry or pietures by introverts for instance, will appeal to children of the extravert temperamint, for so much depends upon such factors as the subjeot and the presentation. It can never be certain that the teacher will lead his pupils to that sympathetic understanding that it is the aim of the lesson in appreciation to give, but I am nevertheless inclined from these experiments to believe that his work will be 1ikely to be successful only in so far as he considers the temperaments of his pupils in conjunction with the subject matter of his lessons. This is no new aiscovery, but it is a prinoiple which is too widely overlooked at the present time by teachers in all departments of our New Zealand High Schools. 


\section{FABLS 35}

\section{FREE RECOTJECHI OI}

EXTRA VERT

$$
\begin{aligned}
& \text { Kipling. "Recessional" } \\
& \text { "Ballad of "E⿱一st \& } \\
& \text { Browning, "Pied Piper" }
\end{aligned}
$$$$
\text { Howbolt, "Admirals } \mathrm{A} 11^{\text {" }}
$$$$
\text { Byron, "Ive of weterloo" }
$$$$
\text { Gol daml th "Deserted Viliage" }
$$$$
\text { (Bxtrect) }
$$

\section{IWTROVERE}

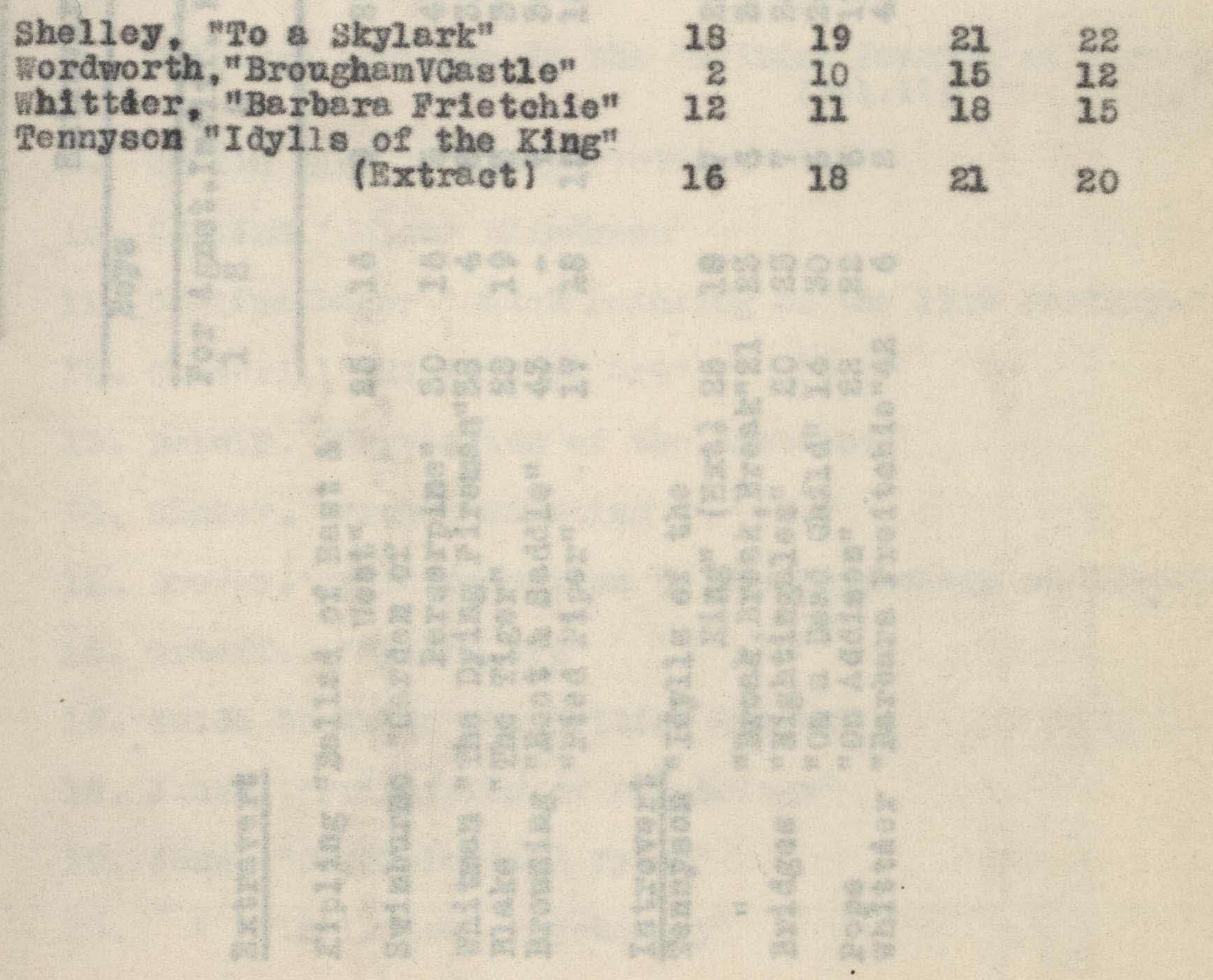




\section{Yable $x_{0} 36$}

REACIION MO FIRST READIMG

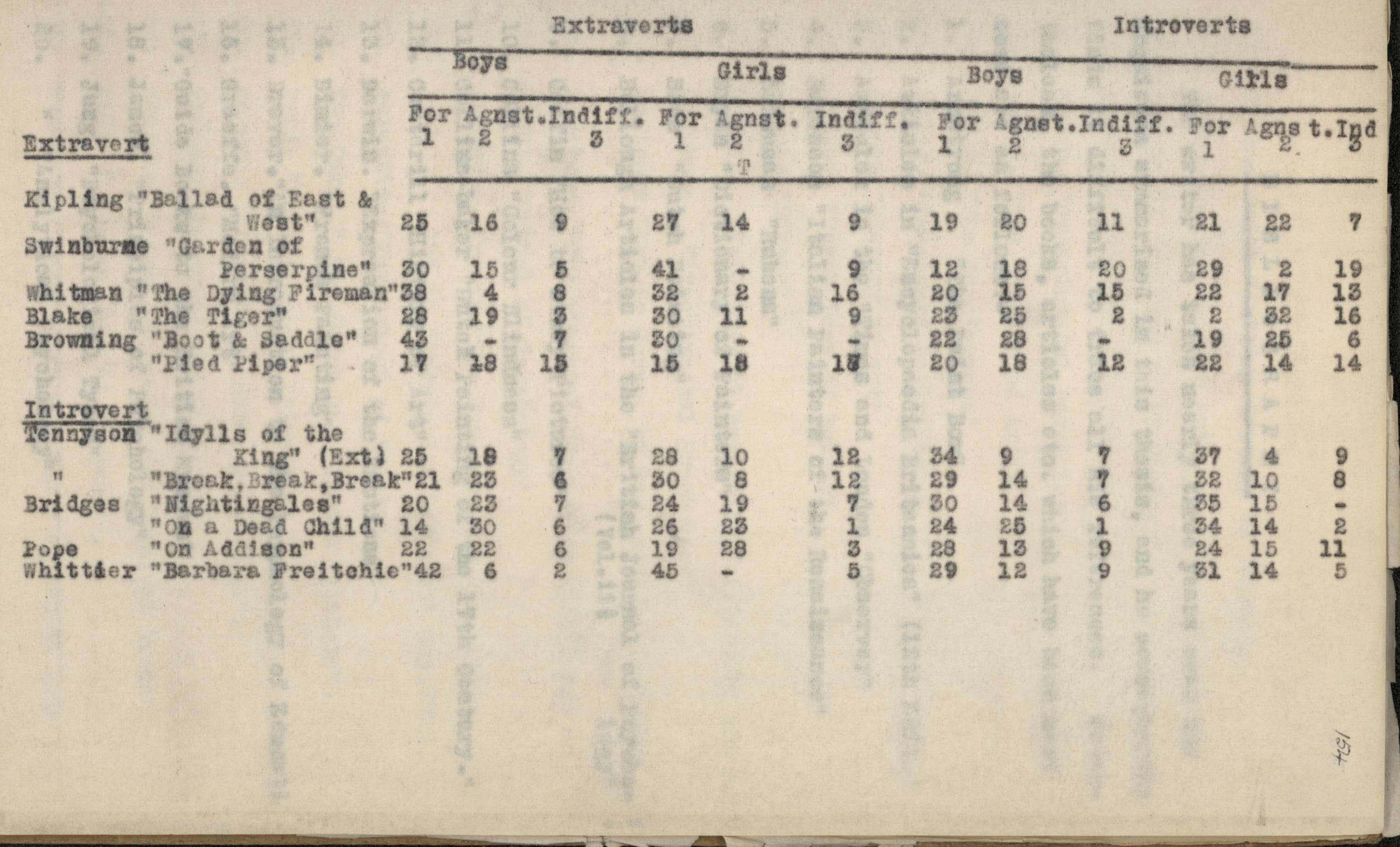


The writer has taken nearly three yoars over the enquiries summarized in this thesis, and he consequentiy linds it alficult to trace all his reforenoes. Nevertheless, the books, axtioles eto. which have been most used are as followe:-

1. Armstrong "The Laint Box"

2. Artieles in "Enoyelopreala Britanniea" (12th Bdit.)

3. Axt1oles in the "gimos and Jondon "Observer"

4. Bexenson "Italian Painters of the Renaissance"

5. Bonsusen "Rubens"

6. Bryan "Diotionary or painters"

7. Bode "Dutch Peinting"

8. Bul.ough Art1cles in the "British Journel of Psycho- V (Vol.11)

9. Caffin "How to straly P1otures"

10. Collins "Colour Blinaness"

11. collins-beker "Dutoh pointing of the 27 th century." 12. Cotter111 "History of Art"

13. Darwin. "Expression of the Emotions"

14. Dimier. "grench peinting"

35. Drever."An Introduotion to the Psychology of Bduats 16. Groeffe, "Hodern Art"

17." "unide Books to the British Nuseum"

18. James. "prinoiples of Psychology"

19. Jung. "Psychological Types"

20. " "Analyt1cal Psychology" 
21. Kaines Smith "Outline History of Painting"

22. Meier-Graefe. "Modern Art"

23. MoDougall "Outline of Psychology"

24. Muther. "History of Peinting"

25. Myers. "Experimental Psyohology"

26. Orpen. "The Outline of Art".

27. Pater. "The Renaissance".

28. Pater. "Imaginary Portraits"

29. Pijoan "History of Art

30. Puffer. "Pryohologg of Beauty"

31. Rooses "Rukens"

32. Sohulze. "Frperimental Psychology" (Trans.by Pintacr)

33. Seashoro. "Experimental Psychology"

34. Seligman "Art in Journ. of Roy. Anthrop.Inst.| Vol.IiV 1924.1,

38. Stratton. "Experimental Psychology \& Culture"

36. Stout. "Manuel of Psychology"

37. Thornton. Art in "The New Age" May 4th, 1922.

38. " Art in "Burlington Magazine" May, I920.

39. Valentine:"Psychology of Beauty".

40. Van Dyke: " O1d Dutch and Flemiah Painters".

4I. Ward: "Psychological Prinoiples."

42. Warren: "Elements of Human Psyohology".

43. Wedmore :"Painters and Painting".

44. Whipple:"Manual of Mentel and Physical Tests".

45. Witt: "How to Look at Pictures".

46. Woodworth:"Pgychology - A Study of liental Life". 

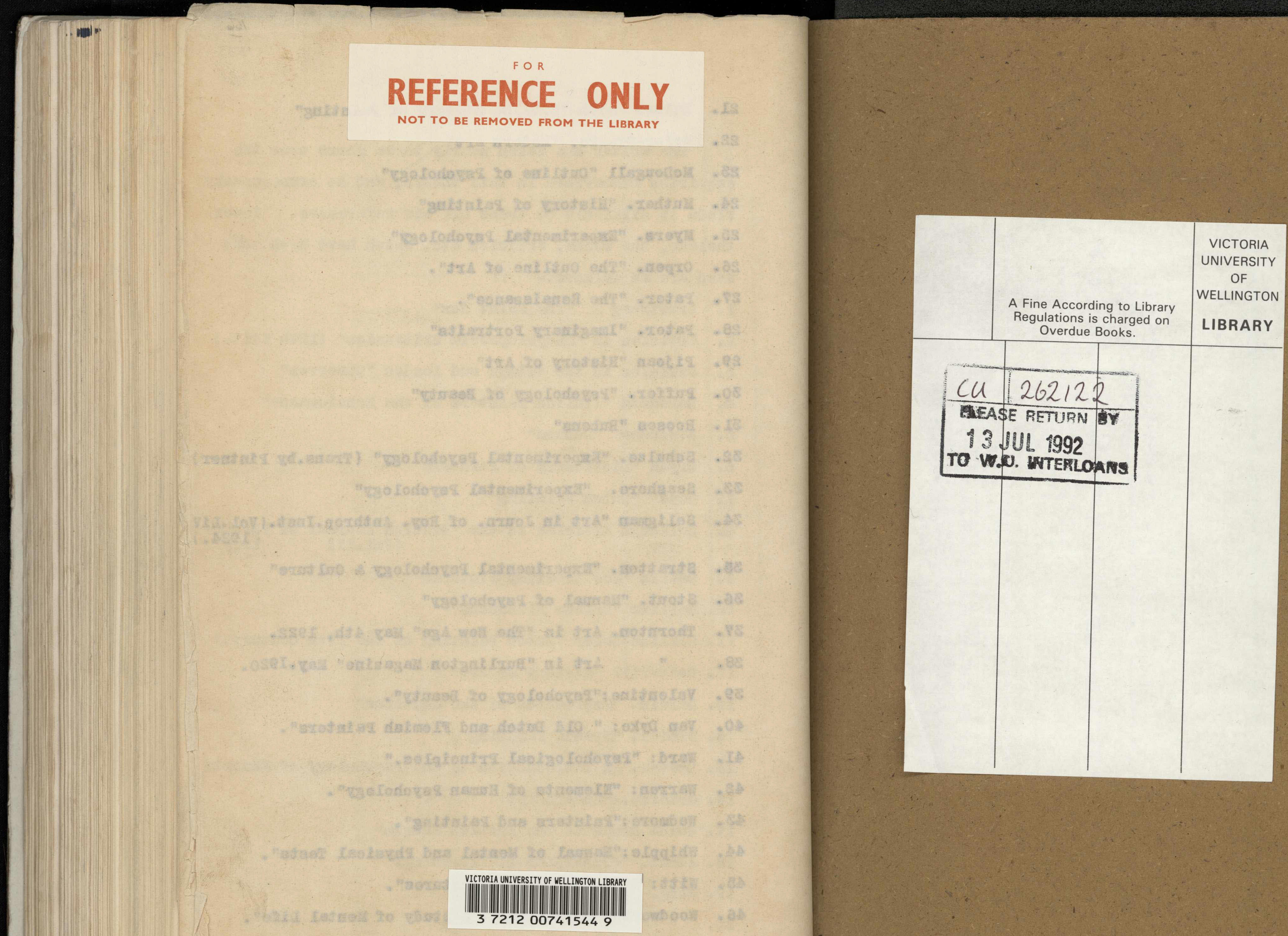


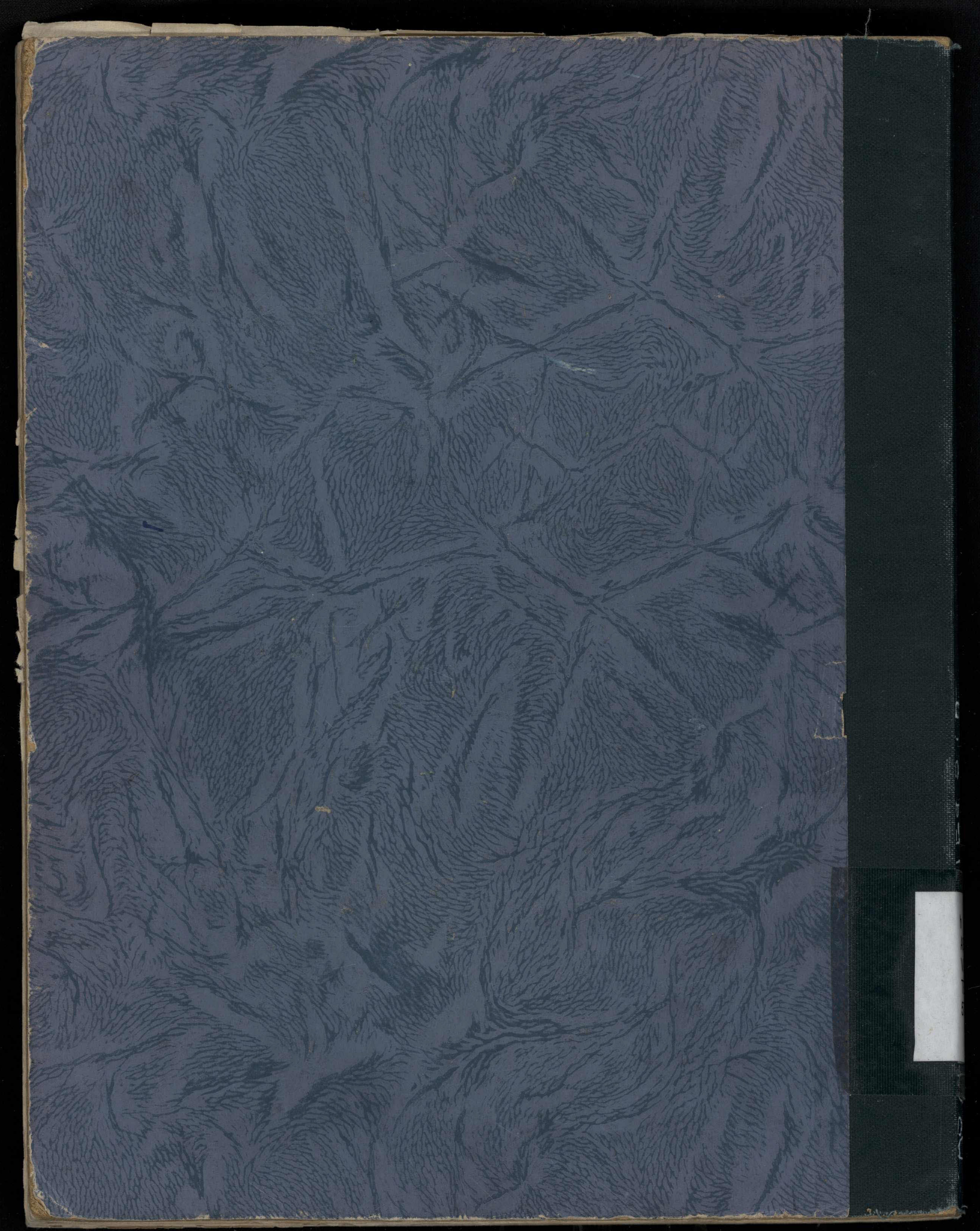

